\title{
Site Specific Phenylation of Pyridine Catalyzed by Phosphido-Bridged Ruthenium Dimer Complexes: A Prototype for C-H Arylation of Electron-Deficient Heteroarenes
}

\author{
Kamil Godula, Bengü Sezen and Dalibor Sames* \\ Department of Chemistry, Columbia University, 3000 Broadway, New York, NY 10027
}

\section{Supporting Information}

\section{Materials and General Methods}

$\mathrm{Ru}_{3}(\mathrm{CO})_{12}$, triphenylphosphine, iodobenzene and anhydrous 2-methyl-2-propanol were purchased from Aldrich and used without further purification. Pyridine was freshly distilled under argon over calcium hydride prior to each reaction. Cesium carbonate was purchased from Strem and dried under vacuo at $150^{\circ} \mathrm{C}$ for 2 hours prior to each reaction. Complex $\mathbf{1}^{1}$ and $\mathrm{Ru}_{3}\left(\mathrm{PPh}_{3}\right)_{2}(\mathrm{CO})_{10}{ }^{2}$ were prepared according to published procedures.

The coupling reactions were performed in closed systems (using pressure vessels having screw caps equipped with a re-sealable PTFE/silicone liner that allows the application of inert atmosphere techniques) due to the low boiling points of the starting materials and solvent (See pictures below). The upper part of the tubes must be cooled efficiently to ensure a sufficient concentration of reagents in the reaction mixture. Without cooling, the caps do not hold the pressure built up in the system at $150{ }^{\circ} \mathrm{C}$. Attempts at scaling up the reported coupling process using standard Schlenk glassware have failed so far. This issue is currently being addressed in our laboratories.

a)

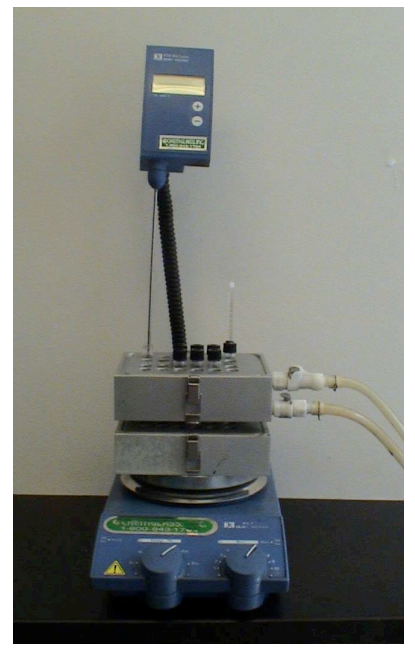

b)

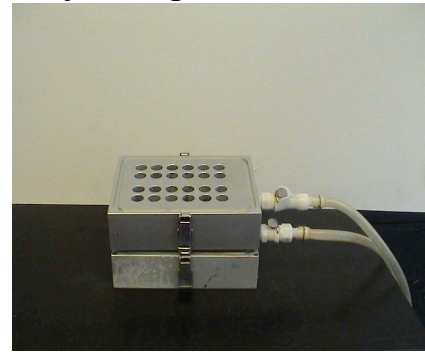

c)

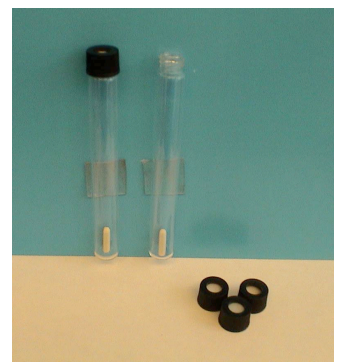

The experimental setup is shown. The reaction bloc] (Fig. b) is composed of two separate components for heating the lower parts and cooling the upper parts of the pressure vessels (Fig. c) inserted in the holes. The reaction block containing up to 24 pressure vessels is placed on a hot plate (Fig. a). Similar reaction blocks are available from J-Kem Scientific (www.jkem.com) and Variomag (www.variomag.com).

The yields reported in the following coupling reactions refer to isolated yields of pure products (average of two or more runs). Purity was established by NMR analysis. All samples of complexes for X-Ray and elemental analyses were prepared by 
crystallization from $\mathrm{CH}_{2} \mathrm{Cl}_{2}$ /pentane mixtures. The reactions were sensitive to the presence of oxygen and were run under an argon atmosphere.

${ }^{1} \mathrm{H},{ }^{13} \mathrm{C}$ and ${ }^{31} \mathrm{P}$ NMR spectra were recorded on Bruker 300 Fourier transform NMR spectrometers. Spectra were recorded in $\mathrm{CDCl}_{3}$ and $\mathrm{C}_{6} \mathrm{D}_{6}$ referenced to TMS or the solvent residual peak, ${ }^{31} \mathrm{P}$ NMR were referenced to internal standard of $75 \% \mathrm{H}_{3} \mathrm{PO}_{4}$. IR spectra were taken as $\mathrm{KBr}$ pellets using BioRad FTS 7000 FT-IR spectrometer. High Resolution Mass Spectra were obtained on a JOEL JMS-HX110 HF mass spectrometer. Elemental analyses were performed by Schwartzkopf Microanalytical Laboratory, Inc. in Woodside, New York. Flash chromatography was performed on Silicycle Silia-P flash silica gel (40-63 $\mu \mathrm{m}$ particle size, $60 \AA$ pore size), filtrations were performed on Aldrich Celite $^{\circledR} 521$.

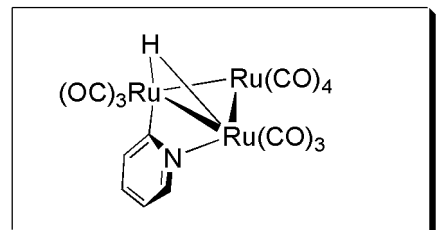

$\mathbf{R u}_{\mathbf{3}}(\boldsymbol{\mu}-\mathbf{H})\left(\boldsymbol{\mu}-\mathrm{NC}_{\mathbf{5}} \mathbf{H}_{\mathbf{4}}\right)(\mathbf{C O})_{\mathbf{1 0}}(\mathbf{1})$. Complex 1 was prepared according to a literature procedure ${ }^{2}$ with the exception that an excess of pyridine was employed ( 7.5 equiv). Column chromatography (10-50\% ethyl acetate/hexanes) gave the product as an orange solid (41\%). ${ }^{1} \mathrm{H}$ NMR data were

identical to those published.

${ }^{1} \mathrm{H}$ NMR (300 MHz, $\left.\mathrm{C}_{6} \mathrm{D}_{6}\right)$ :
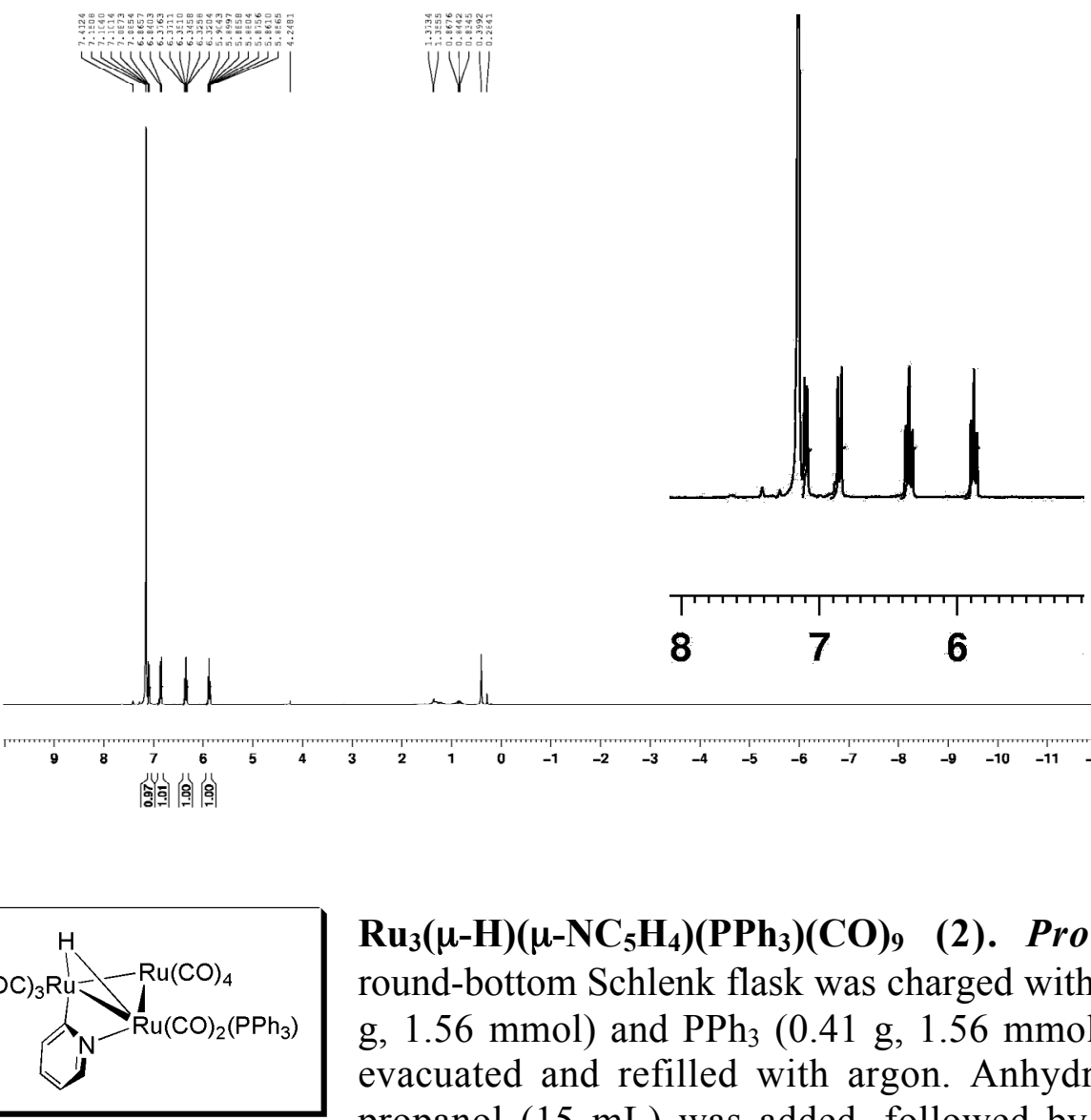

$\mathrm{Ru}_{3}(\mu-\mathrm{H})\left(\mu-\mathrm{NC}_{5} \mathrm{H}_{4}\right)\left(\mathrm{PPh}_{3}\right)(\mathrm{CO})_{9}$ (2). Procedure A: Dry round-bottom Schlenk flask was charged with $\mathrm{Ru}_{3}(\mathrm{CO})_{12}(1.00$ $\mathrm{g}, 1.56 \mathrm{mmol})$ and $\mathrm{PPh}_{3}(0.41 \mathrm{~g}, 1.56 \mathrm{mmol})$. The flask was evacuated and refilled with argon. Anhydrous 2-methyl-2propanol $(15 \mathrm{~mL})$ was added, followed by freshly distilled pyridine $(1 \mathrm{~mL}, 12.4 \mathrm{mmol})$. The flask was equipped with a water condenser and the 
content heated under a weak stream of argon at $100^{\circ} \mathrm{C}$ until bright orange solid precipitated out. After this time $(2 \mathrm{hrs})$ TLC showed complete conversion of $\mathrm{Ru}_{3}(\mathrm{CO})_{12}$ $\left(\mathrm{R}_{\mathrm{f}}=0.76,20 \%\right.$ ethyl acetate/hexanes $)$ into the product $\left(\mathrm{R}_{\mathrm{f}}=0.49,20 \%\right.$ ethyl acetate/hexanes). After cooling the reaction mixture to room temperature, the solvent and excess of pyridine was removed under vacuum. The residue was purified by column chromatography on silica (20\% $\mathrm{CH}_{2} \mathrm{Cl}_{2}$ /hexanes) to give complex $\mathbf{2}$ as an orange solid $(1.00 \mathrm{~g}, 71 \%)$.

Procedure B: Dry Schlenk seal tube was charged with complex 1 (20.0 mg, $0.03 \mathrm{mmol})$ and $\mathrm{PPh}_{3}$ (7.9 mg, $\left.0.03 \mathrm{mmol}\right)$. The tube was sealed, evacuated and refilled with argon. Anhydrous 2-methyl-2-propanol was added and the tube was sealed and heated at $100^{\circ} \mathrm{C}$ for $1 \mathrm{hr}$. After this time TLC showed a complete conversion of the starting material $\left(\mathrm{R}_{\mathrm{f}}=\right.$ $0.62,20 \%$ ethyl acetate/hexanes $)$ into the product $\left(\mathrm{R}_{\mathrm{f}}=0.49,20 \%\right.$ ethyl acetate/hexanes $)$. The reaction mixture was allowed to cool to room temperature and the solvent was removed under reduced pressure. The residue was purified by column chromatography on silica (20\% $\mathrm{CH}_{2} \mathrm{Cl}_{2} /$ hexanes) to give complex 2 as an orange solid (26.5 $\left.\mathrm{mg}, 98 \%\right)$.

${ }^{1} \mathrm{H}$ NMR (300 MHz, $\left.\mathrm{C}_{6} \mathrm{D}_{6}\right) \delta$ ppm: 7.36-7.28 (m, 6H); $7.05\left(\mathrm{dd}, \mathrm{J}_{1}=1.0 \mathrm{~Hz}, \mathrm{~J}_{2}=4.8 \mathrm{~Hz}\right.$, $1 \mathrm{H}) ; 6.99\left(\mathrm{dd}, \mathrm{J}_{1}=1.0 \mathrm{~Hz}, \mathrm{~J}_{2}=7.6 \mathrm{~Hz}, 1 \mathrm{H}\right) ; 6.91-6.85(\mathrm{~m}, 9 \mathrm{H}) ; 6.35\left(\mathrm{dt}, \mathrm{J}_{1}=1.3 \mathrm{~Hz}, \mathrm{~J}_{2}=\right.$ $7.5 \mathrm{~Hz}, 1 \mathrm{H}) ; 5.64\left(\mathrm{ddd}, \mathrm{J}_{1}=1.5 \mathrm{~Hz}, \mathrm{~J}_{2}=5.7 \mathrm{~Hz}, \mathrm{~J}_{3}=7.2 \mathrm{~Hz}, 1 \mathrm{H}\right) ;-13.8(\mathrm{~d}, \mathrm{~J}=11.9 \mathrm{~Hz}$, $1 \mathrm{H})$.

${ }^{13} \mathrm{C}$ NMR (75 MHz, $\left.\mathrm{CDCl}_{3}\right) \delta$ ppm: 210.1, 207.0, 206.6, 202.1, 199.8, 197.7, 192.9, $191.4,179.1,153.5,138.06,134.0,133.4,133.3,133.1,132.19,130.0,128.5,128.4$, 120.03 (observed complexity due to P-C splitting; definitive assignments have not been made).

${ }^{31} \mathrm{P}$ NMR (121 MHz, $\left.\mathrm{CDCl}_{3}\right) \delta$ ppm: 36.7.

MS $\left(\mathrm{FAB}^{+}\right.$) Calcd for $\mathrm{C}_{32} \mathrm{H}_{20} \mathrm{NO}_{9} \mathrm{PRu}_{3}: \mathrm{m} / \mathrm{z}=897.80$. Found $\mathrm{m} / \mathrm{z}=897.95$.

IR (KBr pellet, $\left.\mathrm{cm}^{-1}\right)$ : 3054, 2080, 2036, 2015, 2006, 1990, 1982, 1974, 1964, 1947 , $1438,742,698,586,575,562,520$.

Anal. Calcd for $\mathrm{C}_{32} \mathrm{H}_{20} \mathrm{NO}_{9} \mathrm{PRu}_{3}$ : C, 42.86; H, 2.25; N, 1.56. Found: C, 43.06; H, 2.43; N, 1.52 .

A crystal suitable for X-Ray analysis was prepared using diffusion technique $\left(\mathrm{CH}_{2} \mathrm{Cl}_{2} /\right.$ Pentane $)$. For ortep diagram, bond lengths and angles of complex 2 see pages $\mathrm{S} 23-\mathrm{S} 26$. 
${ }^{1} \mathrm{H}$ NMR (300 MHz, $\left.\mathrm{C}_{6} \mathrm{D}_{6}\right)$ :

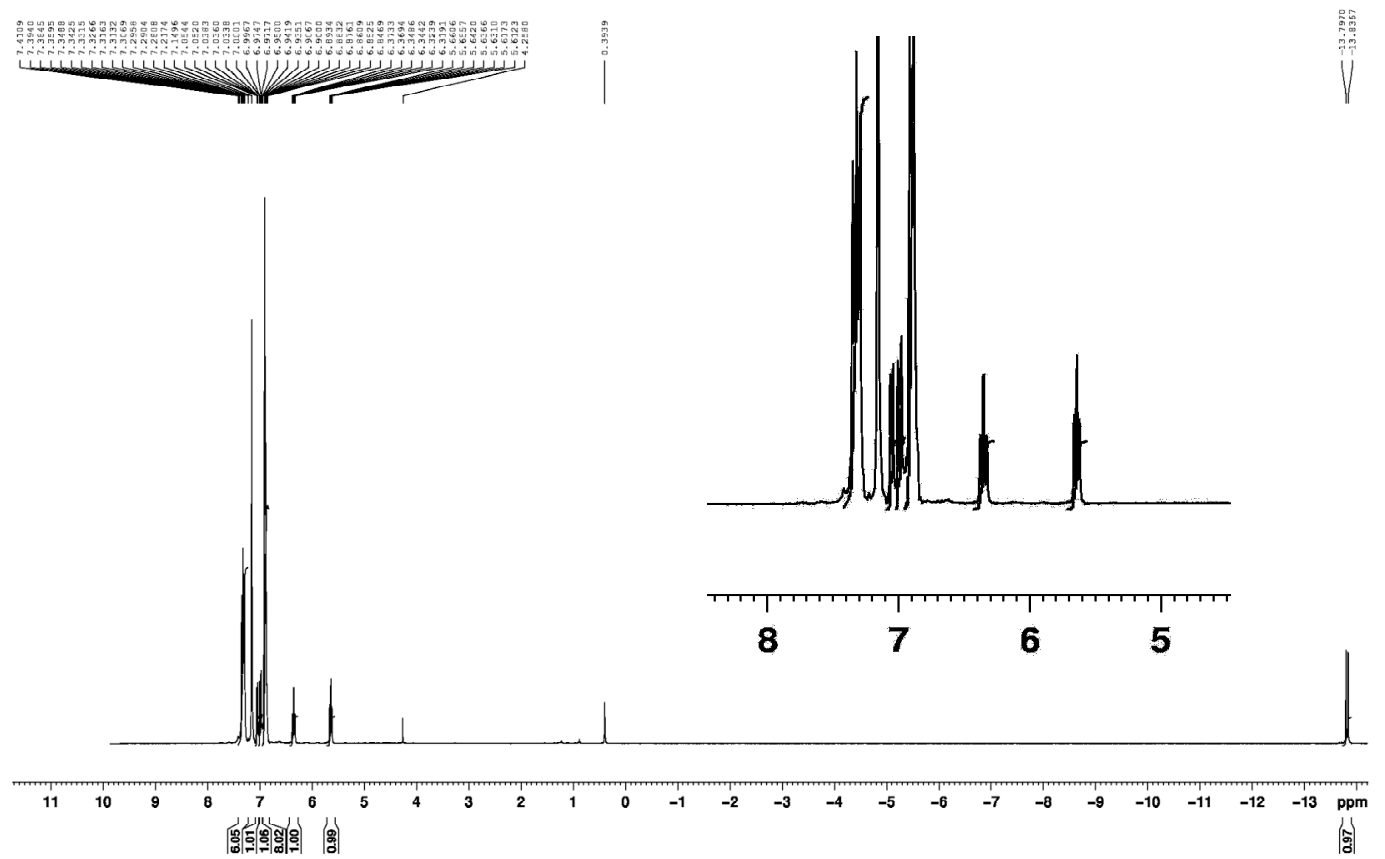

${ }^{13} \mathrm{C}$ NMR (75 MHz, $\left.\mathrm{CDCl}_{3}\right)$ :

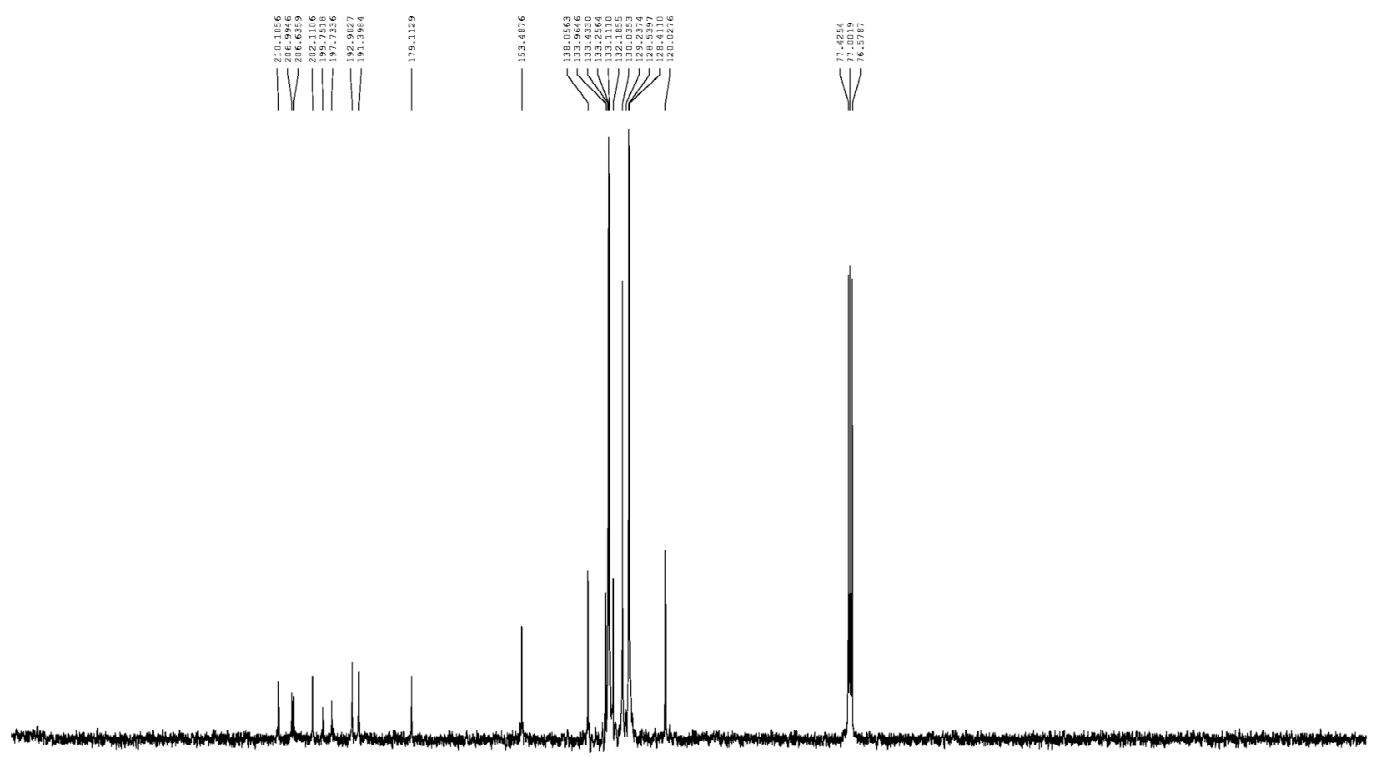

$\begin{array}{llllllllllllllllllllllllllllllllllllll}260 & 250 & 240 & 230 & 220 & 210 & 200 & 190 & 180 & 170 & 160 & 150 & 140 & 130 & 120 & 110 & 100 & 90 & 80 & 70 & 60 & 50 & 40 & 30 & 20 & 10 & 0 & -10 & -20 & -30 & p p m\end{array}$ 
${ }^{31} \mathrm{P}$ NMR (121 MHz, $\left.\mathrm{CDCl}_{3}\right)$ :

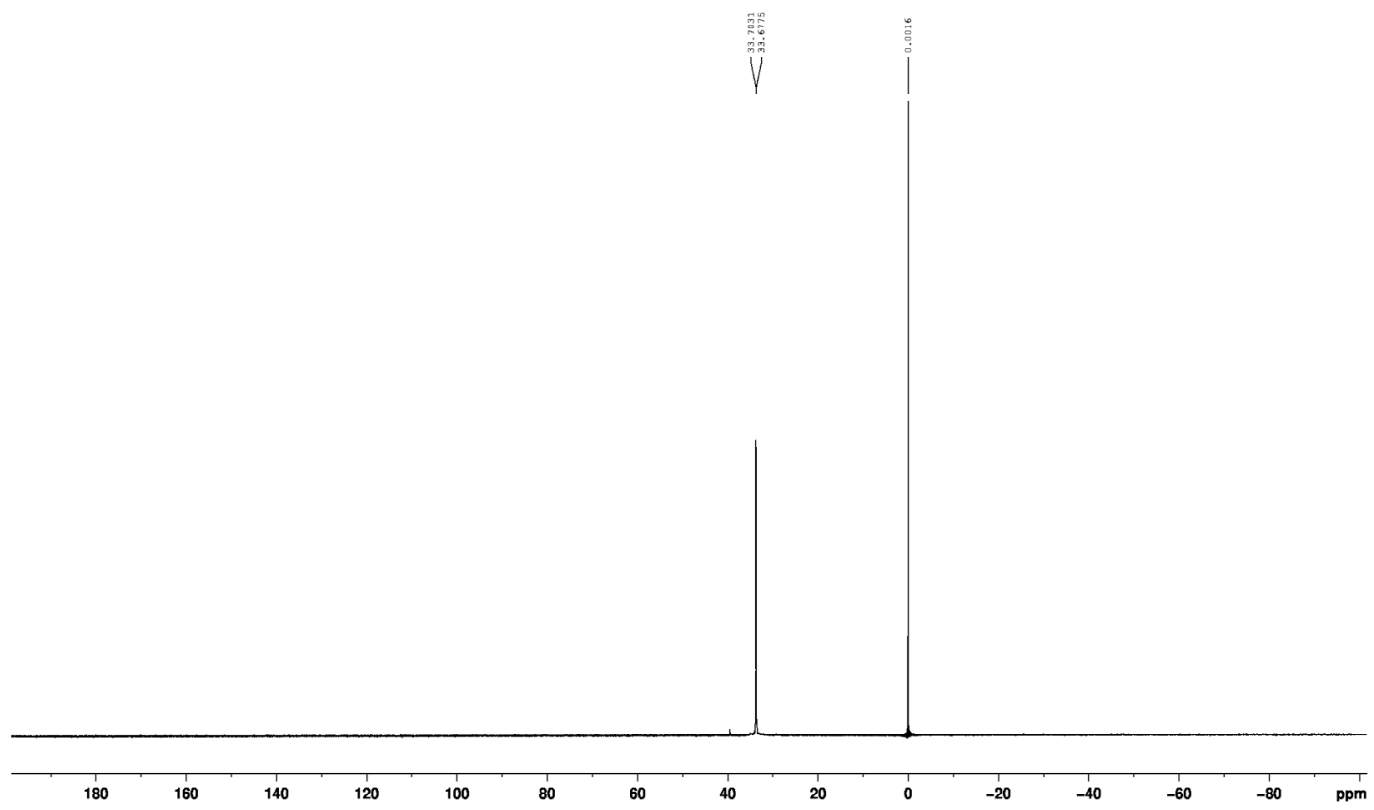

IR ( $\mathrm{KBr}$ pellet, $\left.\mathrm{cm}^{-1}\right)$ :

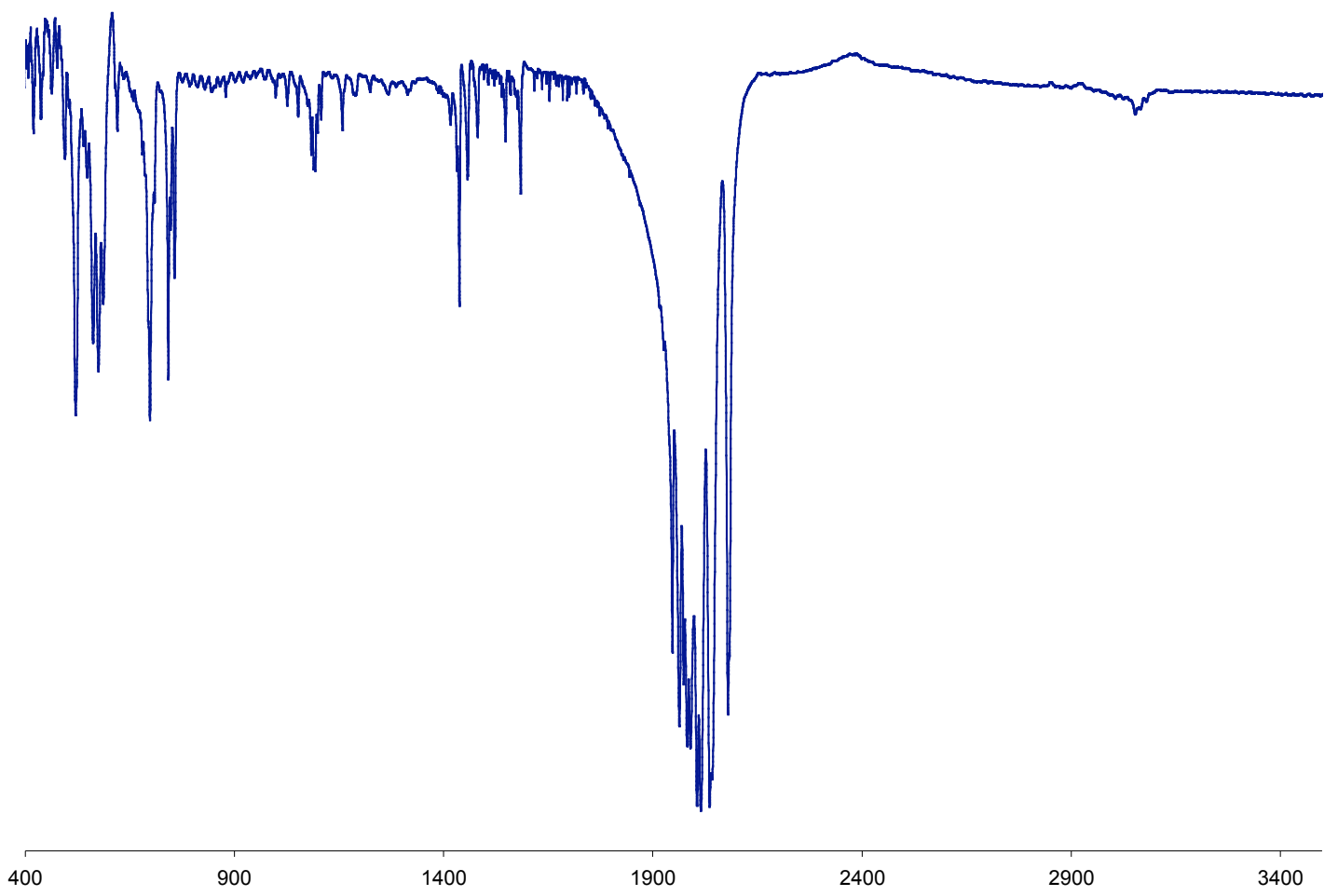




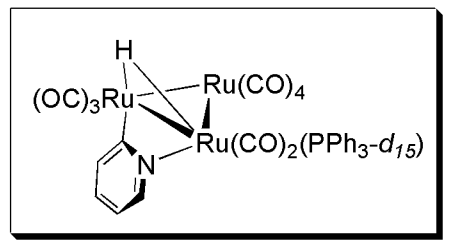

$\mathrm{Ru}_{3}(\mu-\mathrm{H})\left(\boldsymbol{\mu}-\mathrm{NC}_{5} \mathrm{H}_{4}\right)\left(\mathrm{PPh}_{\mathbf{3}}-\boldsymbol{d}_{15}\right)(\mathrm{CO})_{\mathbf{9}}\left(\boldsymbol{d}_{15}-\mathbf{2}\right)$. Complex $\boldsymbol{d}_{15} \mathbf{- 2}$ was prepared from $\mathrm{Ru}_{3}(\mathrm{CO})_{12}(0.5 \mathrm{~g}, 0.78 \mathrm{mmol}), \mathrm{PPh}_{3}-d_{15}$ $(0.2 \mathrm{~g}, 0.78 \mathrm{mmol})$ and pyridine $(0.5 \mathrm{~mL}, 6.2 \mathrm{mmol})$ in a fashion similar to that for preparation of complex 2. Column chromatography on silica gel $\left(20 \% \quad \mathrm{CH}_{2} \mathrm{Cl}_{2} /\right.$ hexanes $)$ followed by crystallization from $\mathrm{CH}_{2} \mathrm{Cl}_{2}$ /pentane solvent system yielded $0.45 \mathrm{~g}$ of crystalline orange product (62\%). NMR data were analogous to those of 2.

${ }^{1} \mathrm{H}$ NMR (300 MHz, $\left.\mathrm{C}_{6} \mathrm{D}_{6}\right)$ :

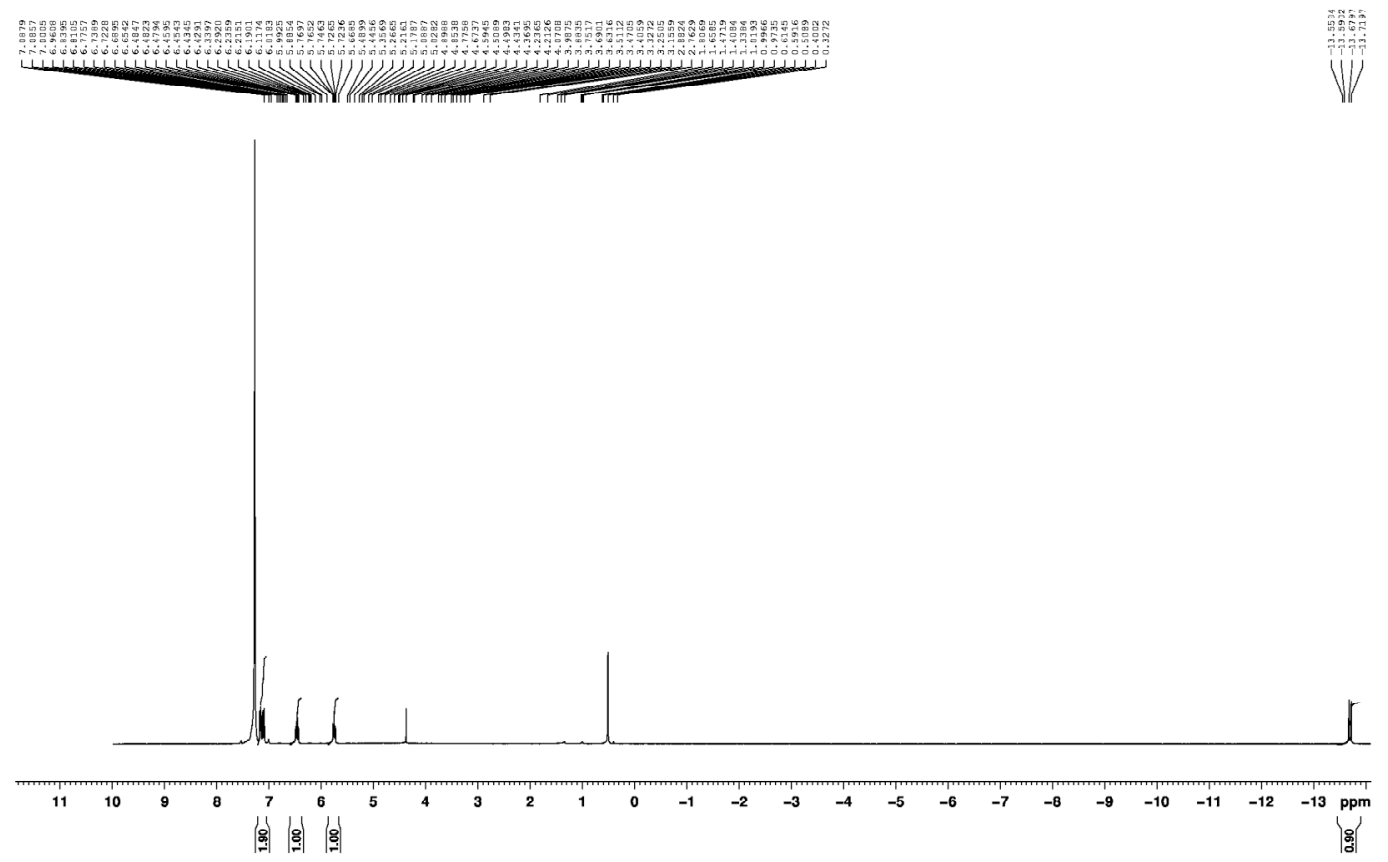

${ }^{31} \mathrm{P}$ NMR (121 MHz, $\left.\mathrm{CDCl}_{3}\right)$ :

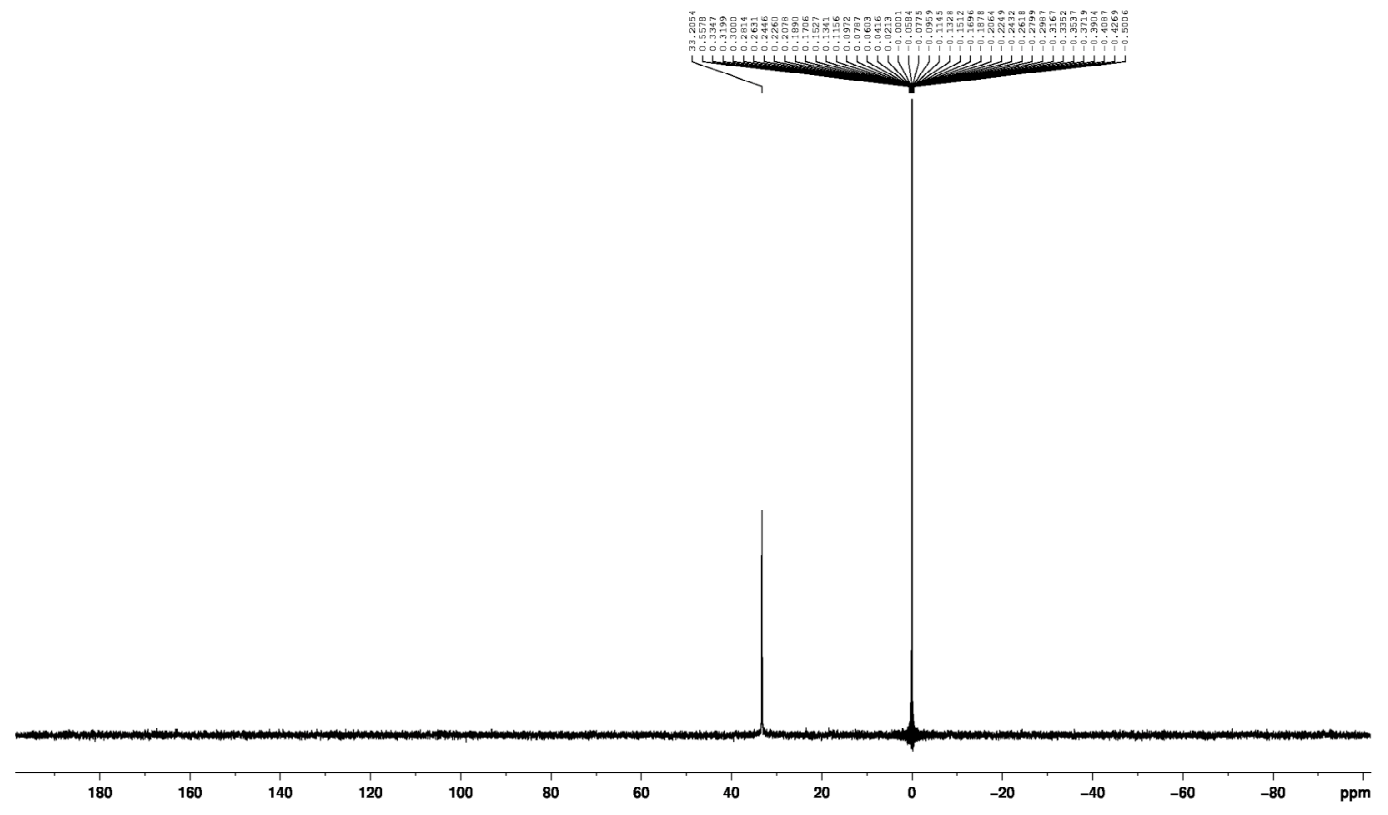




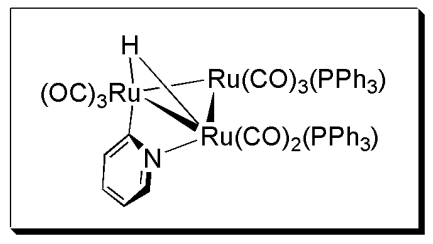

$\mathrm{Ru}_{3}(\mu-\mathrm{H})\left(\mu-\mathrm{NC}_{5} \mathrm{H}_{4}\right)\left(\mathrm{PPh}_{3}\right)_{2}(\mathrm{CO})_{8}$ (3). Dry round-bottom Schlenk flask was charged with complex 2 (400 mg, 0.45 mmol) and $\mathrm{PPh}_{3}(117 \mathrm{mg}, 0.45 \mathrm{mmol})$. The flask was evacuated and refilled with argon. Anhydrous 2-methyl-2propanol $(5 \mathrm{~mL})$ was added. The flask was equipped with a water condenser and the content heated under a weak stream of argon at $100^{\circ} \mathrm{C}$ until all starting material was consumed ( $1 \mathrm{hr}$ ) as evidenced by TLC. New orange spot with $\mathrm{R}_{\mathrm{f}}=$ 0.42 (20\% ethyl acetate/hexanes) was observed. The reaction was allowed to cool to room temperature and the solvent was removed under vacuum. The residue was chromatographed on silica gel $\left(20 \% \mathrm{CH}_{2} \mathrm{Cl}_{2} /\right.$ hexanes $)$ to give the product as an orange solid (263 mg, 52\%). The product underwent partial decomposition on silicagel.

${ }^{1} \mathrm{H}$ NMR $\left(300 \mathrm{MHz}, \mathrm{C}_{6} \mathrm{D}_{6}\right) \delta \mathrm{ppm}$ : 7.77-7.71 (m, 6H); 7.46-7.39 (m, 6H); 7.19-7.10 (m, $2 \mathrm{H}) ; 7.03-6.90(\mathrm{~m}, 18 \mathrm{H}) ; 6.32(\mathrm{t}, \mathrm{J}=7.1 \mathrm{~Hz}, 1 \mathrm{H}) ; 5.64\left(\mathrm{ddd}, \mathrm{J}_{1}=1.3 \mathrm{~Hz}, \mathrm{~J}_{2}=5.8 \mathrm{~Hz}, \mathrm{~J}_{3}=\right.$ $7.1 \mathrm{~Hz}, 1 \mathrm{H}),-13.16(\mathrm{~m}, 1 \mathrm{H})$.

${ }^{13} \mathrm{C}$ NMR $\left(75 \mathrm{MHz}, \mathrm{CDCl}_{3}\right) \delta \mathrm{ppm}: 153.2,137.8,137.2,136.7,134.5,134.0,133.3$, $133.2,133.1,132.3,131.3,129.7,129.5,128.4,128.2,128.2,128.1,126.7,125.7,123.7$, 119.2 (observed complexity due to P-C splitting; definitive assignments have not been made).

${ }^{31} \mathrm{P}$ NMR (121 MHz, $\left.\mathrm{C}_{6} \mathrm{D}_{6}\right) \delta$ ppm: 35.6 (m, 1P), 32.5 (m, 1P).

${ }^{31} \mathrm{P}$ NMR (121 MHz, $\left.\mathrm{CDCl}_{3}\right) \delta$ ppm: $35.3(\mathrm{~m}, 1 \mathrm{P}), 32.0(\mathrm{~m}, 1 \mathrm{P})$.

MS $\left(\mathrm{FAB}^{+}\right)$Calcd for $\mathrm{C}_{49} \mathrm{H}_{35} \mathrm{NO}_{8} \mathrm{P}_{2} \mathrm{Ru}_{3}: \mathrm{m} / \mathrm{z}=1131.90$. Found $\mathrm{m} / \mathrm{z}=1130.9$.

IR $\left(\mathrm{KBr}\right.$ pellet, $\left.\mathrm{cm}^{-1}\right): 3045,2043,2010,1986,1974,1948,1938,1432,740,693,574$, 519.

Anal. Calcd for $\mathrm{C}_{49} \mathrm{H}_{35} \mathrm{NO}_{8} \mathrm{P}_{2} \mathrm{Ru}_{3}: \mathrm{C}, 52.04 ; \mathrm{H}, 3.12 ; \mathrm{N}, 1.24$. Found: C, 52.06; H, 3.03; $\mathrm{N}, 1.16$. 
${ }^{1} \mathrm{H}$ NMR (300 MHz, $\left.\mathrm{C}_{6} \mathrm{D}_{6}\right)$ :

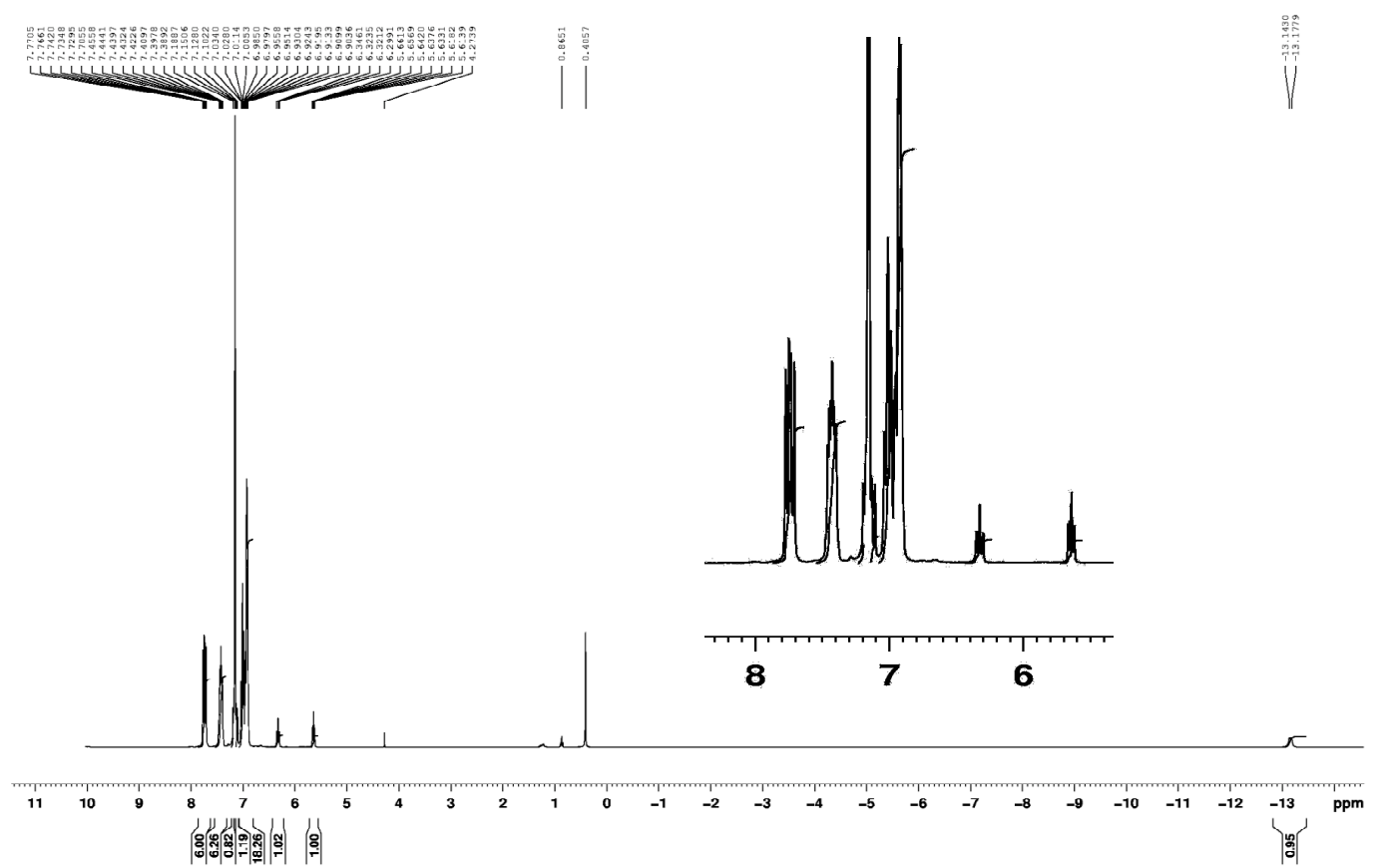

${ }^{13} \mathrm{C}$ NMR (75 MHz, $\left.\mathrm{CDCl}_{3}\right)$ :

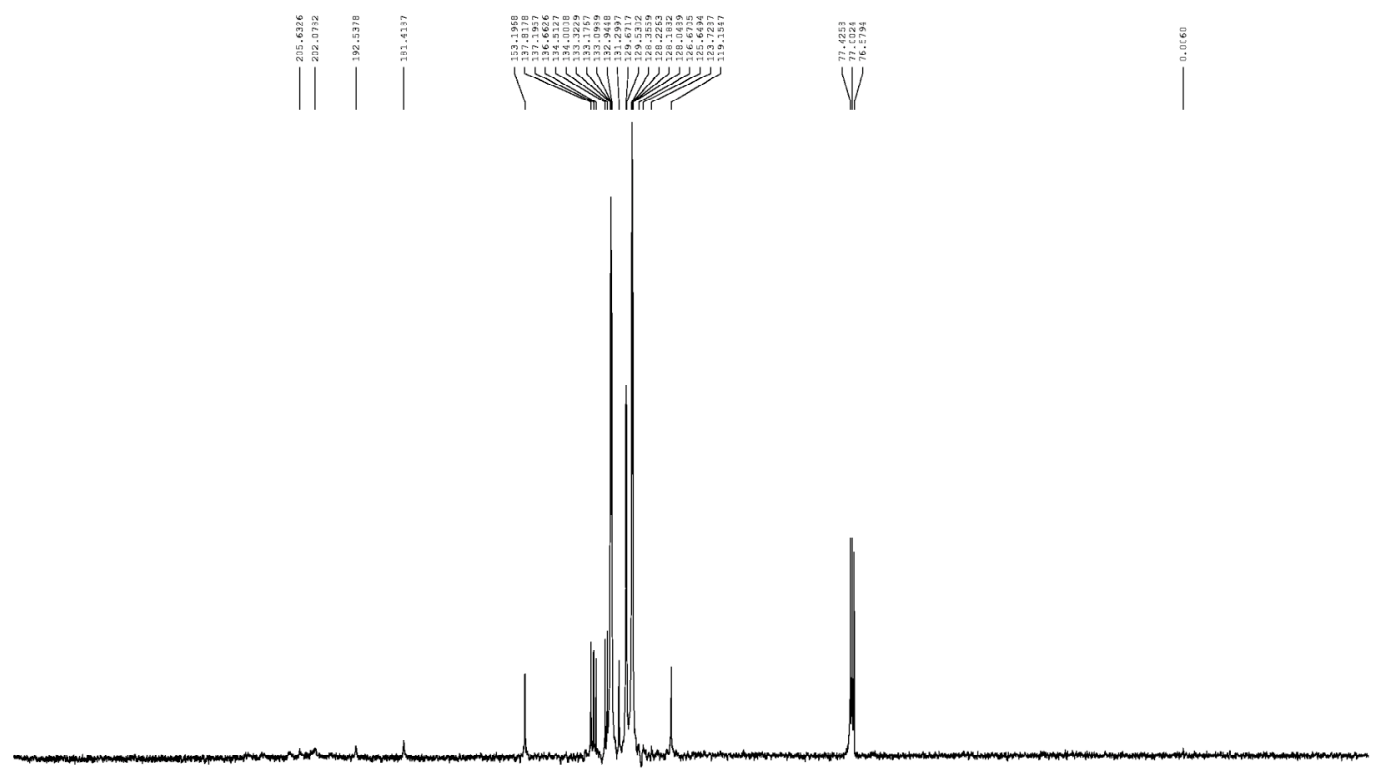

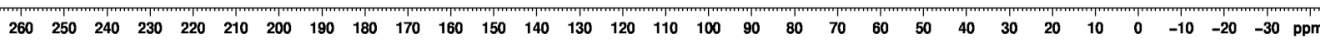


${ }^{31} \mathrm{P}$ NMR (121 MHz, $\left.\mathrm{CDCl}_{3}\right)$ :

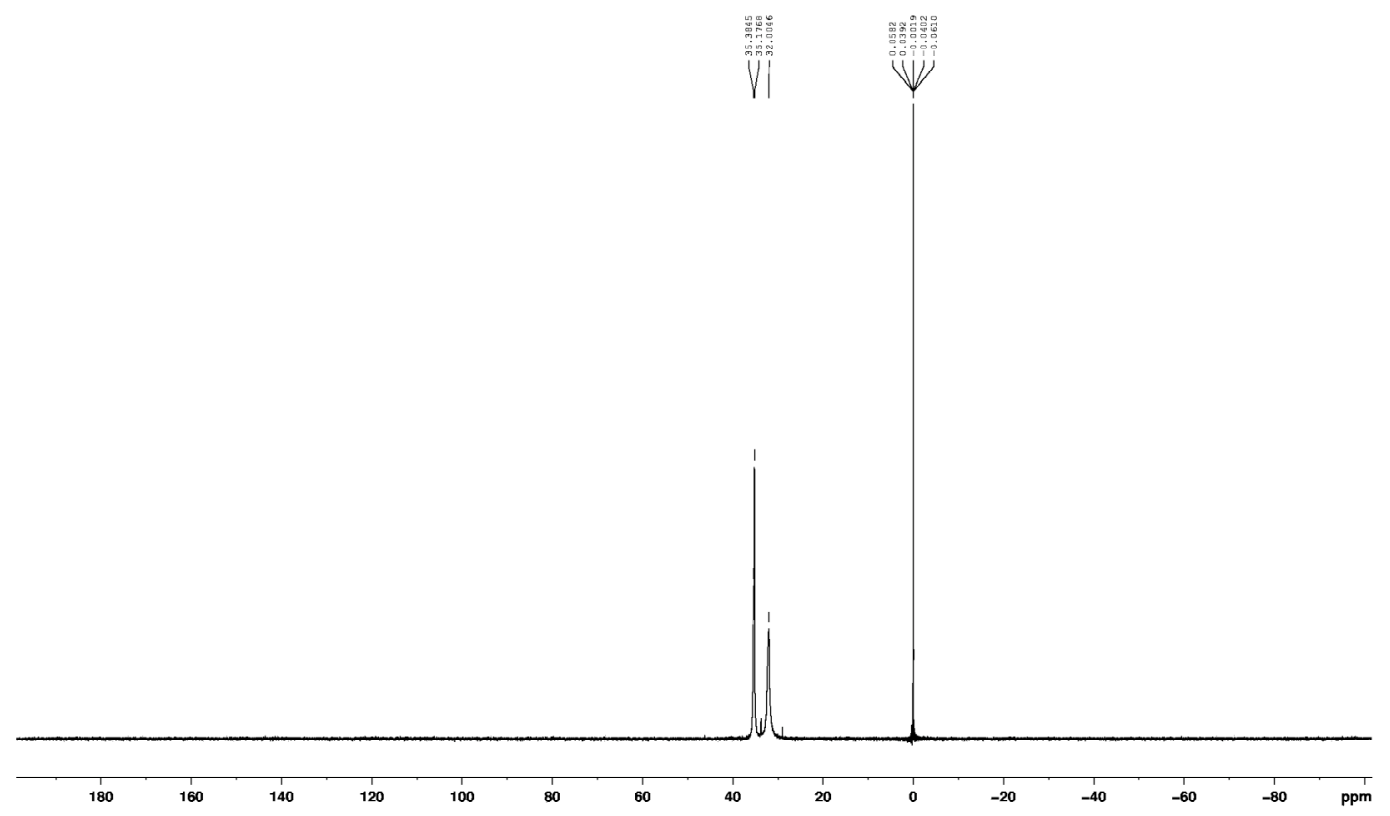

IR ( $\mathrm{KBr}$ pellet, $\left.\mathrm{cm}^{-1}\right)$ :

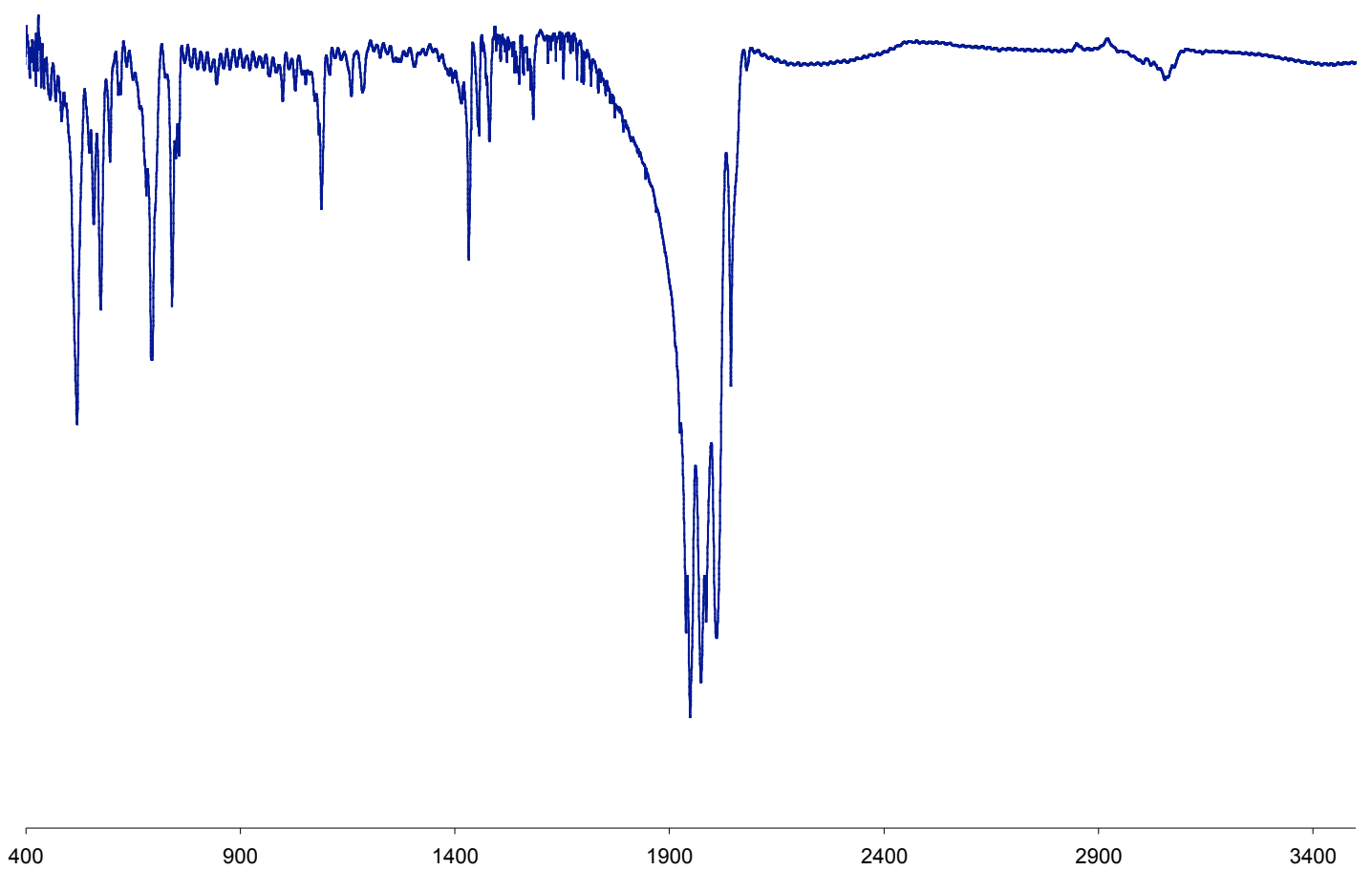




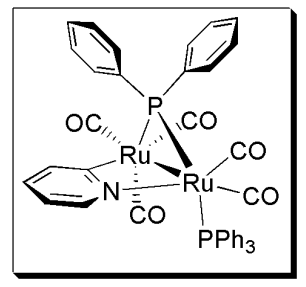

$\mathrm{Ru}_{2}\left(\mu-\mathrm{PPh}_{2}\right)\left(\mu-\mathrm{NC}_{5} \mathrm{H}_{4}\right)\left(\mathrm{PPh}_{3}\right)(\mathrm{CO})_{5}$ (4). Procedure A: Dry roundbottom Schlenk flask was charged with complex 2 (1.35 g, 1.50 $\mathrm{mmol}), \mathrm{PPh}_{3}(0.39 \mathrm{~g}, 1.5 \mathrm{mmol})$ and $\mathrm{Cs}_{2} \mathrm{CO}_{3}(0.80 \mathrm{~g}, 2.25 \mathrm{mmol})$. The flask was evacuated and refilled with argon. Anhydrous 2-methyl-2propanol $(5 \mathrm{~mL})$ was added. The flask was fitted with a water condensor and the content was heated at $100^{\circ} \mathrm{C}$ under a stream of argon (it is important to allow the released $\mathrm{CO}$ to escape from the reaction mixture) until complete conversion of starting material into complex $\mathbf{3}$, as evidenced by TLC. After this time $(1 \mathrm{hr})$ the condenser was removed and the flask was sealed. The reaction mixture was heated at $120^{\circ} \mathrm{C}$ for $7 \mathrm{hrs}$. After this time all intermediates disappeared and only the presence of two new products, complexes $4\left(\mathrm{R}_{\mathrm{f}}=0.52,20 \%\right.$ ethyl acetate/hexanes $)$ and a mixture of complexes $\mathbf{5 a}$ and $\mathbf{5 b}\left(\mathrm{R}_{\mathrm{f}}=0.45,20 \%\right.$ ethyl acetate/hexanes) was observed. After cooling to room temperature the reaction mixture was filtered (Celite), washed $\left(\mathrm{CH}_{2} \mathrm{Cl}_{2}\right)$ and concentrated. The resulting mixture was chromatographed on silica (10$30 \% \mathrm{CH}_{2} \mathrm{Cl}_{2} /$ hexanes) to give complex 4 as a pale yellow solid $(0.26 \mathrm{~g}, 33 \%)$, which was re-crystallized from $\mathrm{CH}_{2} \mathrm{Cl}_{2}$ /pentane solvent system. Complexes 5a and 5b were observed in the crude reaction mixture by NMR, however, decomposed during chromatography and thus could not be isolated.

Procedure B: Dry Schlenk tube was charged with complex $3(22.0 \mathrm{mg}, 0.02 \mathrm{mmol})$ and $\mathrm{Cs}_{2} \mathrm{CO}_{3}(10.0 \mathrm{mg}, 0.03 \mathrm{mmol})$. The tube was evacuated, refilled with argon and anhydrous 2-methyl-2-propanol was added. The tube was sealed and the content was heated at $120^{\circ} \mathrm{C}$ for $2 \mathrm{hrs}$. After this time the reaction was worked up in the same manner as in procedure $\boldsymbol{A}$ yielding complex $\mathbf{4}(6.1 \mathrm{mg}, 36 \%)$ and a mixture of complexes $\mathbf{5 a}$ and $\mathbf{5 b}(2.3 \mathrm{mg}, 10 \%)$ as yellow and red solid, respectively.

${ }^{1} \mathrm{H}$ NMR (300 MHz, $\left.\mathrm{C}_{6} \mathrm{D}_{6}\right) \delta$ ppm: 8.18-8.11 (m, 2H); 7.78-7.63 (m, 8H); 7.10-7.05 (m, $2 \mathrm{H}) ; 6.97-6.88(\mathrm{~m}, 11 \mathrm{H}) ; 6.76-6.65(\mathrm{~m}, 4 \mathrm{H}) ; 6.46(\mathrm{~d}, \mathrm{~J}=5.5 \mathrm{~Hz}, 1 \mathrm{H}) ; 6.07\left(\mathrm{dt}, \mathrm{J}_{1}=1.1\right.$ $\left.\mathrm{Hz}, \mathrm{J}_{2}=7.5 \mathrm{~Hz}, 1 \mathrm{H}\right) ; 5.33(\mathrm{t}, \mathrm{J}=6.4 \mathrm{~Hz}, 1 \mathrm{H})$.

${ }^{13} \mathrm{C}$ NMR (75 MHz, $\left.\mathrm{CDCl}_{3}\right) \delta$ ppm: $206.8(\mathrm{t}, \mathrm{J}=11.7 \mathrm{~Hz}, \mathrm{CO}) ; 206.6(\mathrm{~d}, \mathrm{~J}=63.0 \mathrm{~Hz}$, CO); 204.5 (d, J = 10.1, CO); 200.9 (d, J = 87.1 Hz, CO); 185.3 (d, J = 12.0 Hz, CO); 154.46; $142.4(\mathrm{~d}, \mathrm{~J}=29.7) ; 138.7 ; 139.0(\mathrm{~d}, \mathrm{~J}=25.5 \mathrm{~Hz}) ; 136.5(\mathrm{~d}, \mathrm{~J}=37.3 \mathrm{~Hz}) ; 133.6$; $133.4 ; 130.9 ; 130.4 ; 129.8 ; 129.4 ; 129.0 ; 128.6 ; 128.4 ; 128.1 ; 127.9 ; 127.7 ; 127.33$; $127.21 ; 126.8$ (observed complexity due to P-C splitting; definitive assignments have not been made).

${ }^{31}$ P NMR (121 MHz, $\left.\mathrm{CDCl}_{3}\right) \delta$ ppm: $160.6(\mathrm{~d}, \mathrm{~J}=184.6 \mathrm{~Hz}, 1 \mathrm{P}) ; 43.1(\mathrm{~d}, \mathrm{~J}=184.7 \mathrm{~Hz}$, 1P).

MS $\left(\mathrm{FAB}^{+}\right)$Calcd for $\mathrm{C}_{40} \mathrm{H}_{29} \mathrm{NO}_{5} \mathrm{P}_{2} \mathrm{Ru}_{2}: \mathrm{m} / \mathrm{z}=868.96$. Found $\mathrm{m} / \mathrm{z}=869.1$.

IR $\left(\mathrm{KBr}\right.$ pellet, $\left.\mathrm{cm}^{-1}\right)$ : 3054, 2037, 1986, 1977, 1955, 1920, 1584, 1433, 1090, 740, 692, 521.

Anal. Calcd for $\mathrm{C}_{40} \mathrm{H}_{29} \mathrm{NO}_{5} \mathrm{P}_{2} \mathrm{Ru}_{2}: \mathrm{C}, 55.36 ; \mathrm{H}, 3.37 ; \mathrm{N}, 1.61$. Found: $\mathrm{C}, 55.50 ; \mathrm{H}, 3.48$; $\mathrm{N}, 1.59$. 
A crystal suitable for X-Ray analysis was prepared using diffusion technique $\left(\mathrm{CH}_{2} \mathrm{Cl}_{2} /\right.$ Pentane). For ortep diagram, bond lengths and angles of complex 4 see pages S27-S30.

${ }^{1} \mathrm{H}$ NMR (300 MHz, $\left.\mathrm{C}_{6} \mathrm{D}_{6}\right)$ :

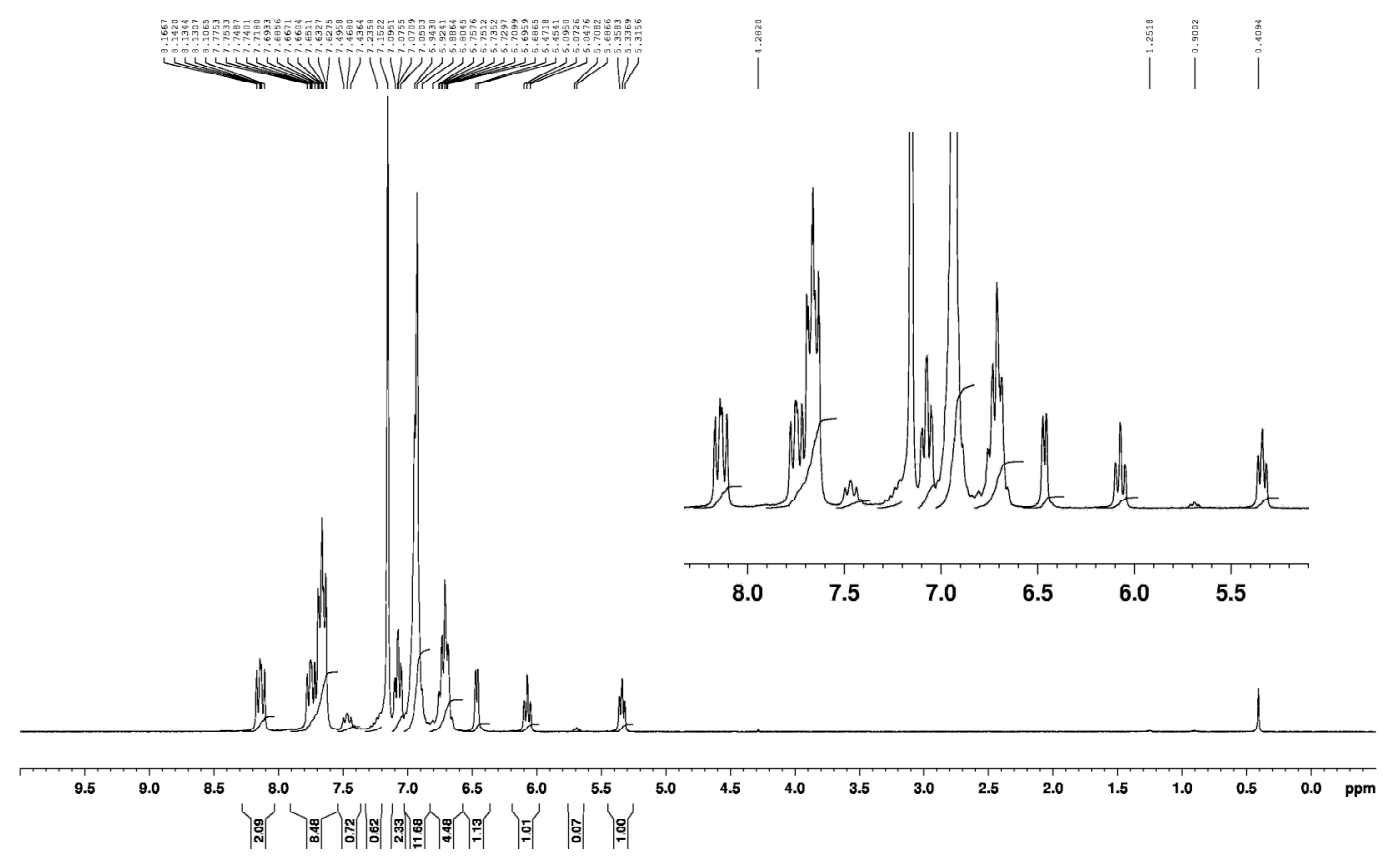

${ }^{13} \mathrm{C}$ NMR $\left(75 \mathrm{MHz}, \mathrm{CDCl}_{3}\right)$ :
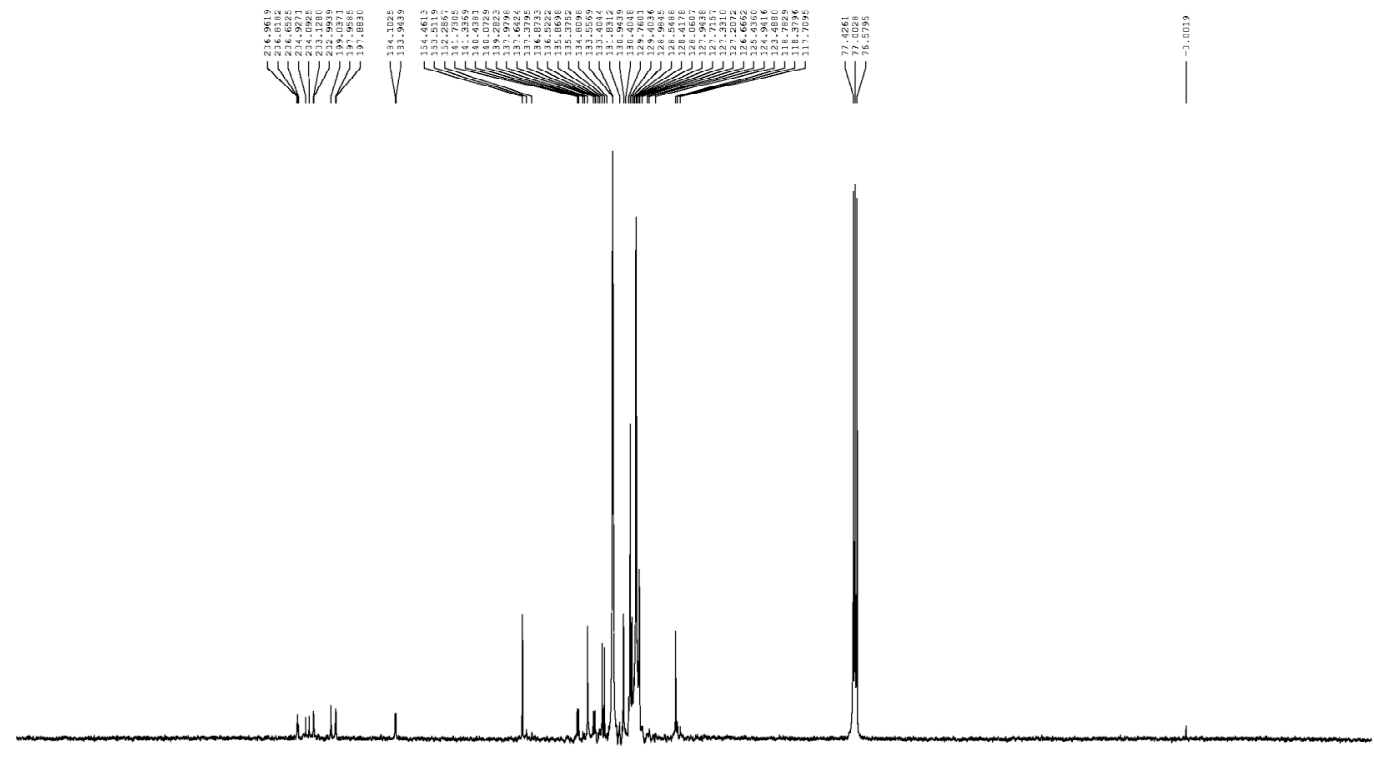

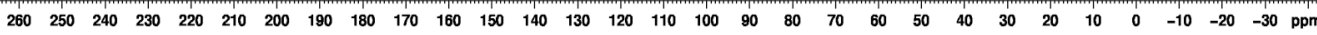


${ }^{31} \mathrm{P}$ NMR (121 MHz, $\left.\mathrm{C}_{6} \mathrm{D}_{6}\right)$ :

||

||

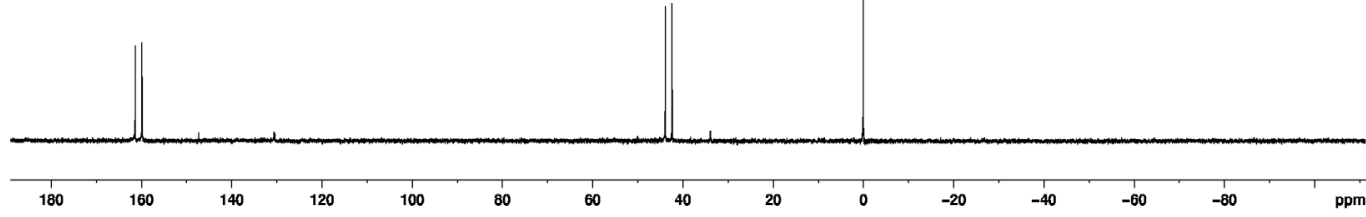

IR ( $\mathrm{KBr}$ pellet, $\left.\mathrm{cm}^{-1}\right)$ :

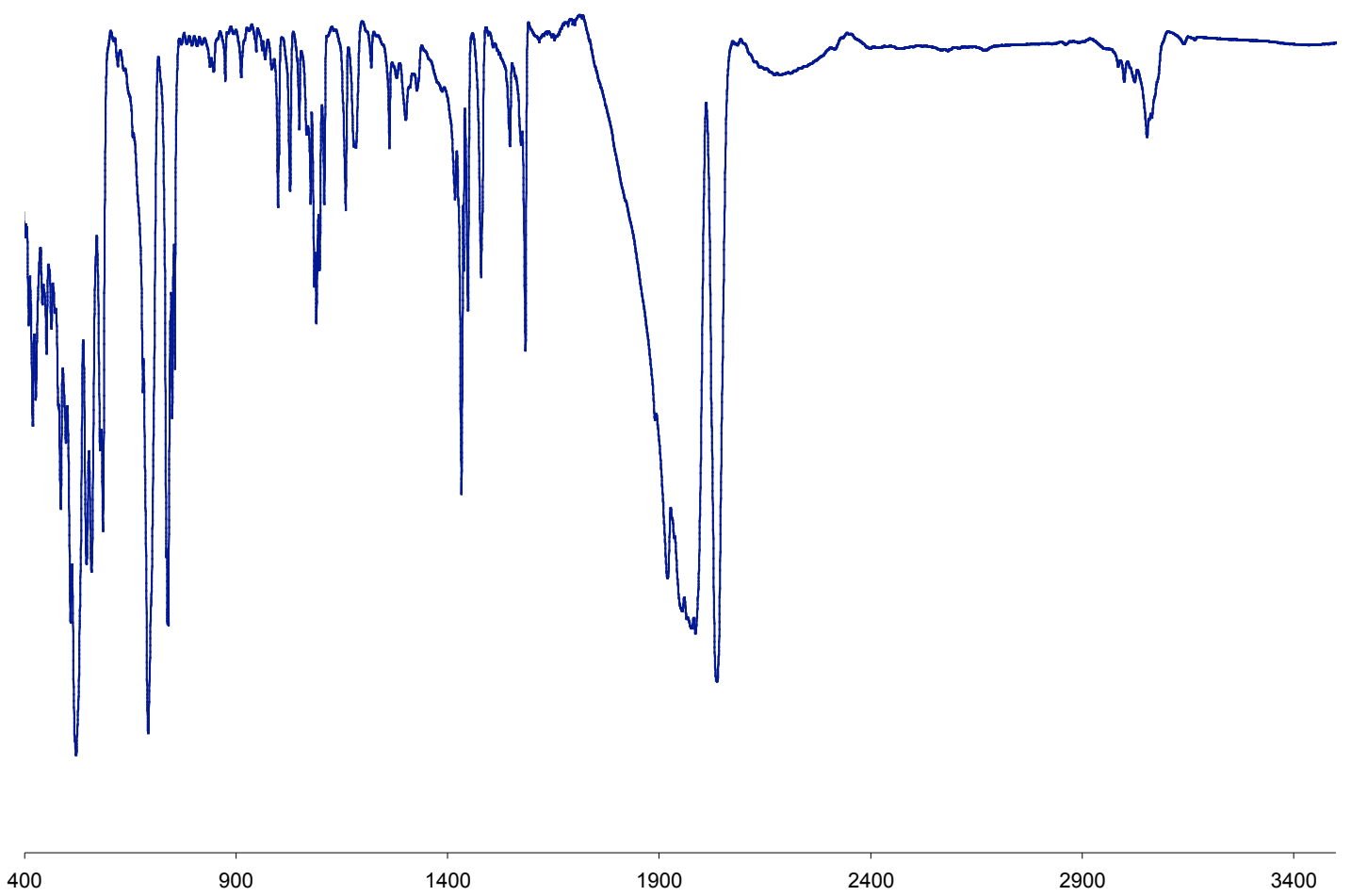




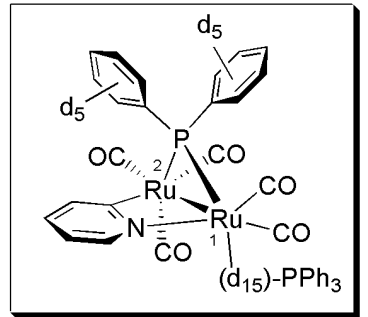

$\mathrm{Ru}_{2}\left(\mu-\mathrm{PPh}_{2}-\boldsymbol{d}_{10}\right)\left(\mu-\mathrm{NC}_{5} \mathrm{H}_{4}\right)\left(\mathrm{PPh}_{3}-\boldsymbol{d}_{15}\right)(\mathrm{CO})_{5}\left(d_{25}-4\right)$. Complex $\boldsymbol{d}_{25^{-}}$ 4 was prepared from $\boldsymbol{d}_{15} \mathbf{- 2}(260 \mathrm{mg}, 0.29 \mathrm{mmol}), \mathrm{PPh}_{3}-d_{15}(79 \mathrm{mg}$, $0.29 \mathrm{mmol})$ in the presence of $\mathrm{Cs}_{2} \mathrm{CO}_{3}(151 \mathrm{mg}, 0.43 \mathrm{mmol})$ in a fashion similar to that for preparation of 4 . Column chromatography on silica (10-30\% $\mathrm{CH}_{2} \mathrm{Cl}_{2} /$ hexanes) gave $85 \mathrm{mg}$ of yellow solid (35\%). NMR indicated a partial D-H exchange into the bridge phenyl groups. NMR data were analogous to those of 4 .

${ }^{1} \mathrm{H}$ NMR (300 MHz, $\left.\mathrm{C}_{6} \mathrm{D}_{6}\right)$ :

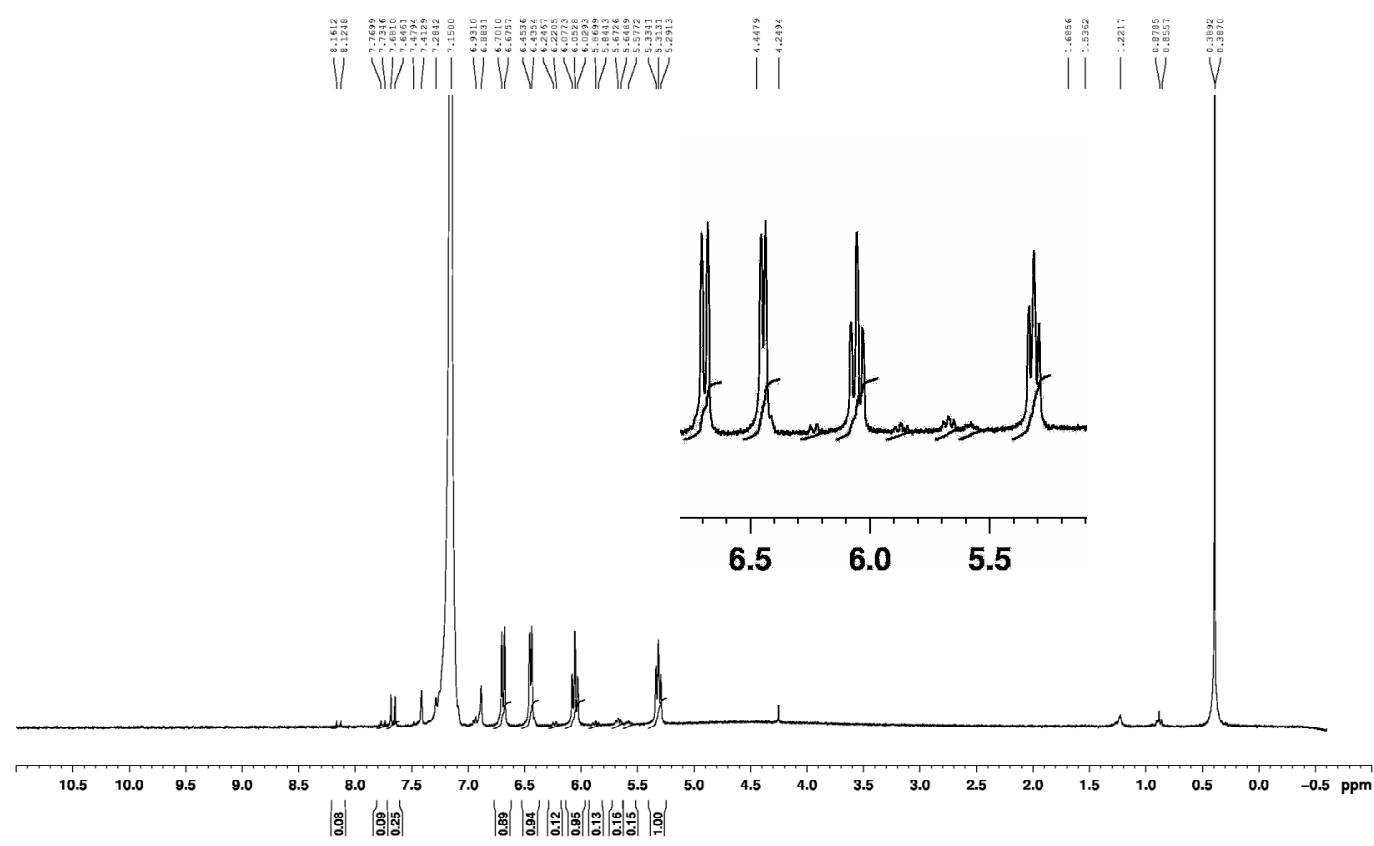

${ }^{31} \mathrm{P}$ NMR (121 MHz, $\left.\mathrm{C}_{6} \mathrm{D}_{6}\right)$ :

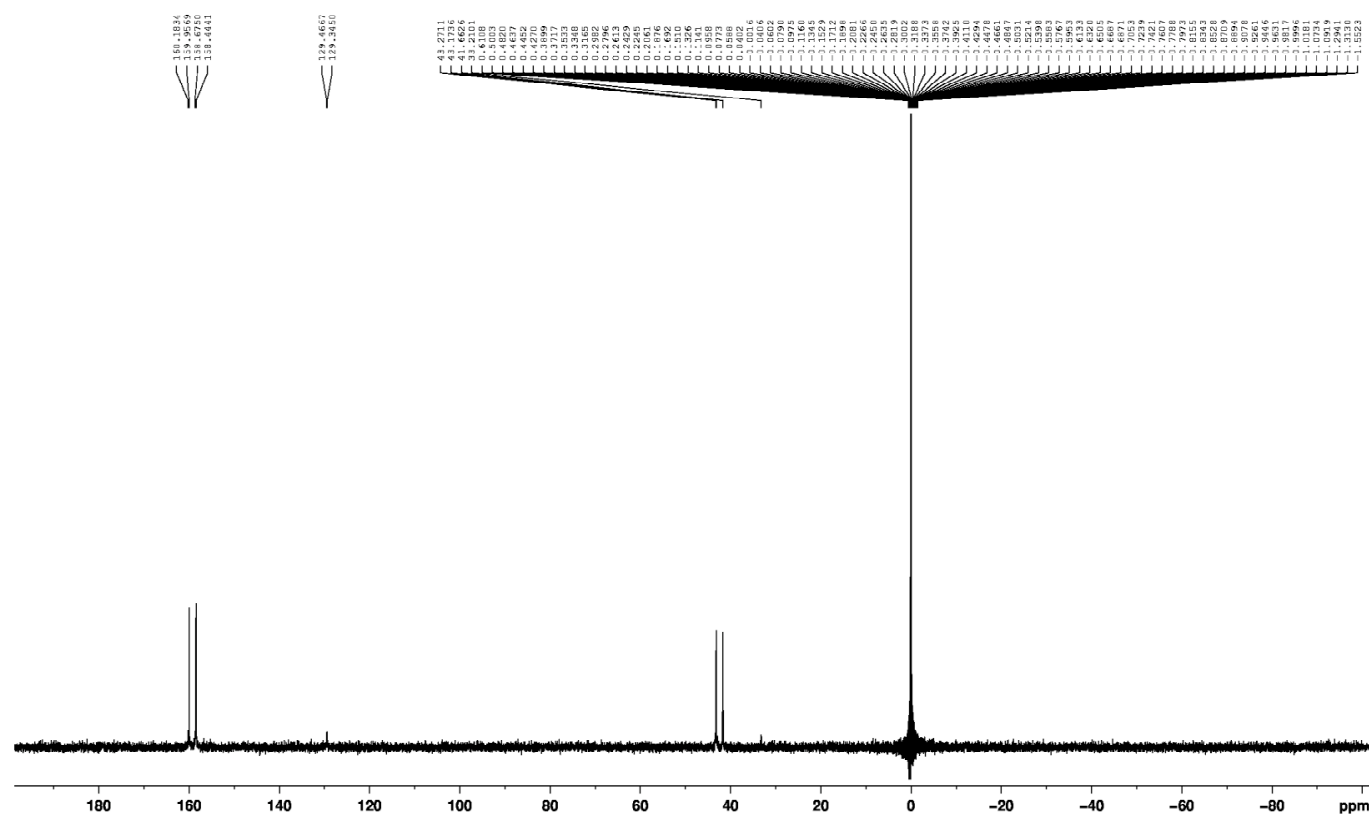




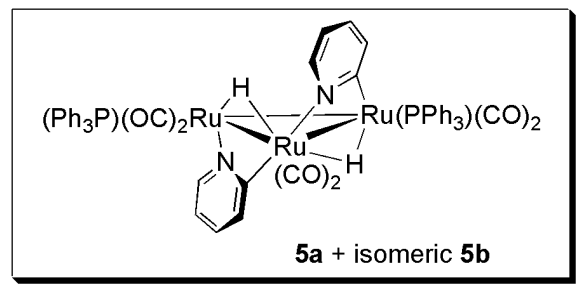

$\mathrm{Ru}_{3}(\mu-\mathrm{H})_{2}\left(\mu-\mathrm{NC}_{5} \mathrm{H}_{4}\right)_{2}\left(\mathrm{PPh}_{3}\right)_{2}(\mathrm{CO})_{6}(5 \mathrm{a}, 5 \mathrm{~b})$. D ry sealable round-bottom Schlenk flask was charged with $\mathrm{Ru}_{3}\left(\mathrm{PPh}_{3}\right)_{2}(\mathrm{CO})_{10}(10 \mathrm{mg}, 0.018 \mathrm{mmol})$. The flask was evacuated and refilled with argon. Anhydrous 2-methyl-2-propanol $(3 \mathrm{~mL})$ was added followed by pyridine $(100 \mu \mathrm{L}, 1.236 \mathrm{mmol})$. The flask was sealed and heated at $110^{\circ} \mathrm{C}$ until the complete conversion of starting material $\left(\mathrm{R}_{\mathrm{f}}=0.32,20 \%\right.$ ethyl acetate/hexanes $)$ into a red product, as evidenced by TLC $\left(\mathrm{R}_{\mathrm{f}}=\right.$ $0.45,20 \%$ ethyl acetate/hexanes). After this time ( $2 \mathrm{hrs}$ ) the reaction was allowed to cool to room temperature and the solvent and excess of pyridine were removed under reduced pressure. The residue was quickly passed through a silica column $\left(50 \% \mathrm{CH}_{2} \mathrm{Cl}_{2} /\right.$ hexanes $)$, prolonged exposure of the complexes to silica gel leads to their complete decomposition. The eluent was concentrated to give $10 \mathrm{mg}(48 \%)$ of a $4: 1$ mixture of 5a and its $\mathrm{C} 2$ symmetric isomer $\mathbf{5 b}$ (with both pyridyl units coordinated through their nitrogen atoms to the same ruthenium center). Sample for X-Ray analysis containing an identical mixture of $\mathbf{5 a}$ and $\mathbf{5 b}$ was obtained by crystallization from $\mathrm{CH}_{2} \mathrm{Cl}_{2} /$ pentane solvent system.

${ }^{1} \mathrm{H}$ NMR (300 MHz, $\left.\mathrm{C}_{6} \mathrm{D}_{6}\right) \delta$ ppm: $7.73(\mathrm{~d}, \mathrm{~J}=4.9 \mathrm{~Hz}, 1 \mathrm{H}, \mathbf{5 a}) ; 7.54-7.39(\mathrm{~m}, 13 \mathrm{H}, \mathbf{5 a}$ and $14 \mathrm{H}, \mathbf{5 b}) ; 7.05(\mathrm{~d}, \mathrm{~J}=7.6,1 \mathrm{H}, \mathbf{5 a}) ; 7.00-6.80(\mathrm{~m}, 19 \mathrm{H}, \mathbf{5 a}$ and $20 \mathrm{H}, \mathbf{5 b}) ; 6.67(\mathrm{t}, \mathrm{J}=$ $7.2 \mathrm{~Hz}, 2 \mathrm{H}, \mathbf{5 b}) ; 6.57(\mathrm{t}, \mathrm{J}=7.4 \mathrm{~Hz}, 1 \mathrm{H}, \mathbf{5 a}) ; 6.34$ (t, J = 7.4 Hz, 1H, 5a); 6.19 (t, J = 6.3 $\mathrm{Hz}, 1 \mathrm{H}, \mathbf{5 a}) ; 5.83(\mathrm{t}, \mathrm{J}=6.5 \mathrm{~Hz}, 2 \mathrm{H}, \mathbf{5 b}) ; 5.75(\mathrm{t}, \mathrm{J}=6.5 \mathrm{~Hz}, 1 \mathrm{H}, \mathbf{5 a}) ;-11.18\left(\mathrm{dd}, \mathrm{J}_{1}=1.7\right.$ $\left.\mathrm{Hz}, \mathrm{J}_{2}=11.2 \mathrm{~Hz}, 1 \mathrm{H}, \mathbf{5 a}\right) ;-12.01(\mathrm{~m}, 1 \mathrm{H}, \mathbf{5 a}$ and $2 \mathrm{H}, \mathbf{5 b})$.

${ }^{13} \mathrm{C}$ NMR $\left(75 \mathrm{MHz}, \mathrm{CDCl}_{3}\right) \delta$ ppm: 210.1, 208.6, 205.1, 203.9, 199.2, 196.0, 195.4, 193.9, 188.4, 177.8, 154.8, 154.6, 152.9, 140.0, 138.4, 137.3, 137.1, 136.8, 135.8, 135.2, 133.2, 133.2, 133.1, 133.0, 131.0, 130.8, 129.2, 128.9, 128.1, 128.0, 127.8, 127.7, 118.9, $188.8,116.9$ (observed complexity due to P-C splitting and presence of two isomeric species in the sample; definitive assignments have not been made).

${ }^{31}$ P NMR (121 MHz, CDCl $) \delta$ ppm: $41.2(\mathrm{~d}, \mathrm{~J}=45.6 \mathrm{~Hz}, 1 \mathrm{P}, \mathbf{5 a}) ; 33.8$ (s, 2P, 5b), 31.6 (d, J = 45.6 Hz, 1P, 5a).

MS (FAB ${ }^{+}$) Calcd for $\mathrm{C}_{52} \mathrm{H}_{40} \mathrm{~N}_{2} \mathrm{O}_{6} \mathrm{P}_{2} \mathrm{Ru}_{3}: \mathrm{m} / \mathrm{z}=1154.95$. Found $\mathrm{m} / \mathrm{z}=1155.1$.

IR (KBr pellet, $\mathrm{cm}^{-1}$ ): 3052, 2023, 1998, 1973, 1954, 1941, 1927, 1433, 738, 692, 515.

Anal. Calcd for $\mathrm{C}_{52} \mathrm{H}_{40} \mathrm{~N}_{2} \mathrm{O}_{6} \mathrm{P}_{2} \mathrm{Ru}_{3}$ : C, 54.12; H, 3.49; N, 2.43. Found: $\mathrm{C}, 53.85 ; \mathrm{H}, 3.14$; $\mathrm{N}, 2.38$.

A crystal suitable for X-Ray analysis was prepared using diffusion technique $\left(\mathrm{CH}_{2} \mathrm{Cl}_{2} /\right.$ Pentane). For ortep diagram, bond lengths and angles of complex 5 see pages S31-S34. 
${ }^{1} \mathrm{H}$ NMR (300 MHz, $\mathrm{C}_{6} \mathrm{D}_{6}$ ):

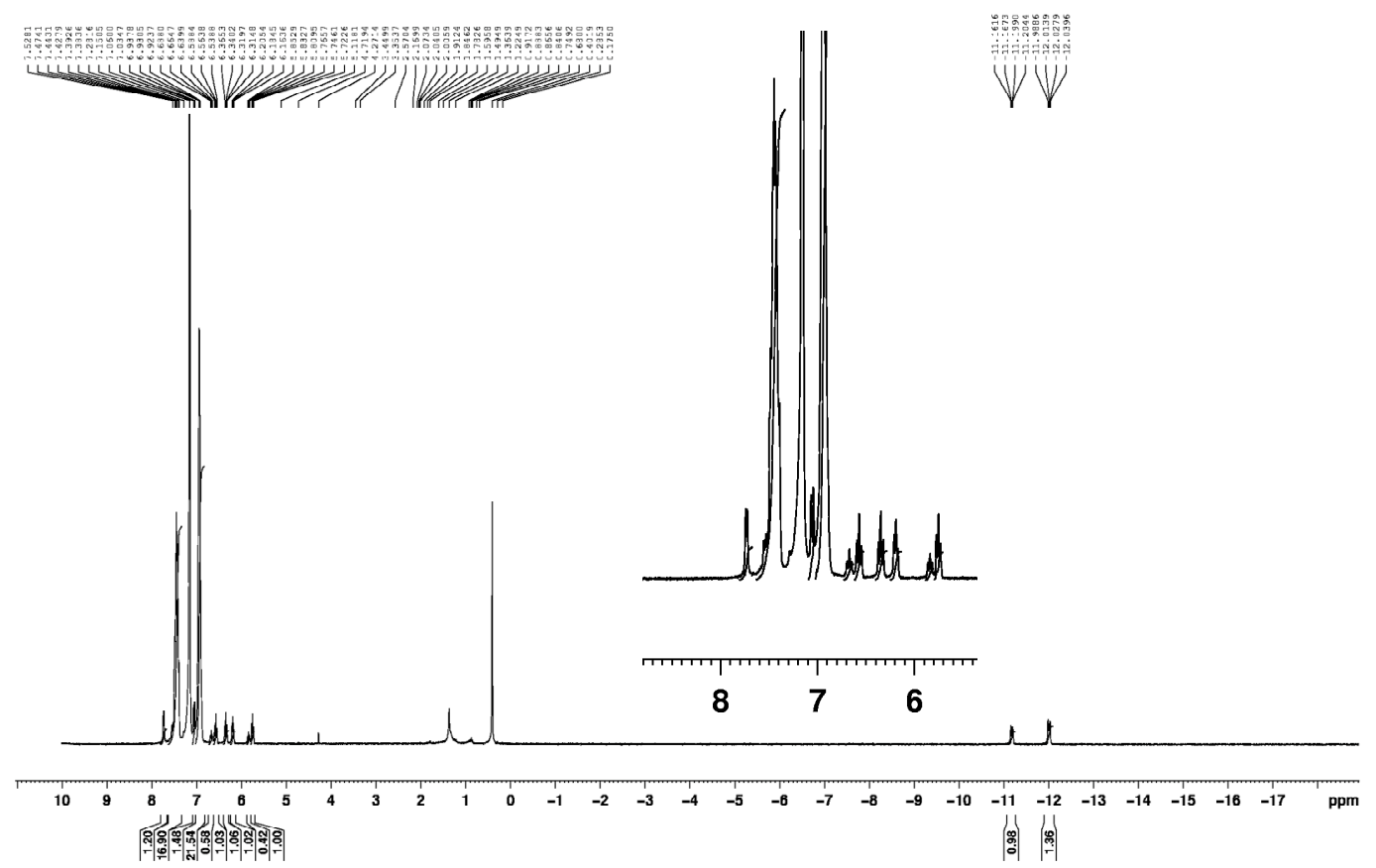

${ }^{13} \mathrm{C}$ NMR (75 MHz, $\left.\mathrm{CDCl}_{3}\right)$ :
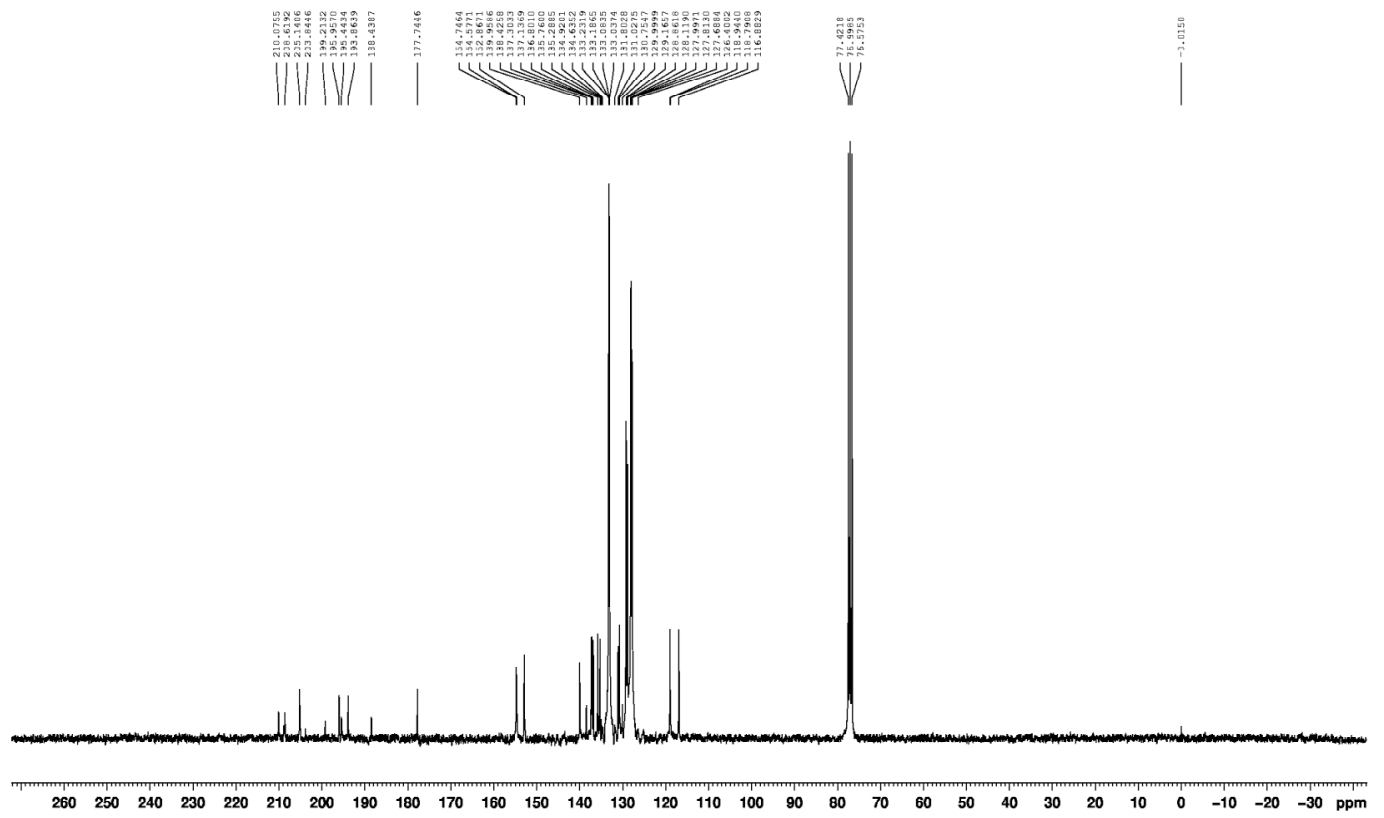
${ }^{31} \mathrm{P}$ NMR (121 MHz, $\left.\mathrm{CDCl}_{3}\right)$ :

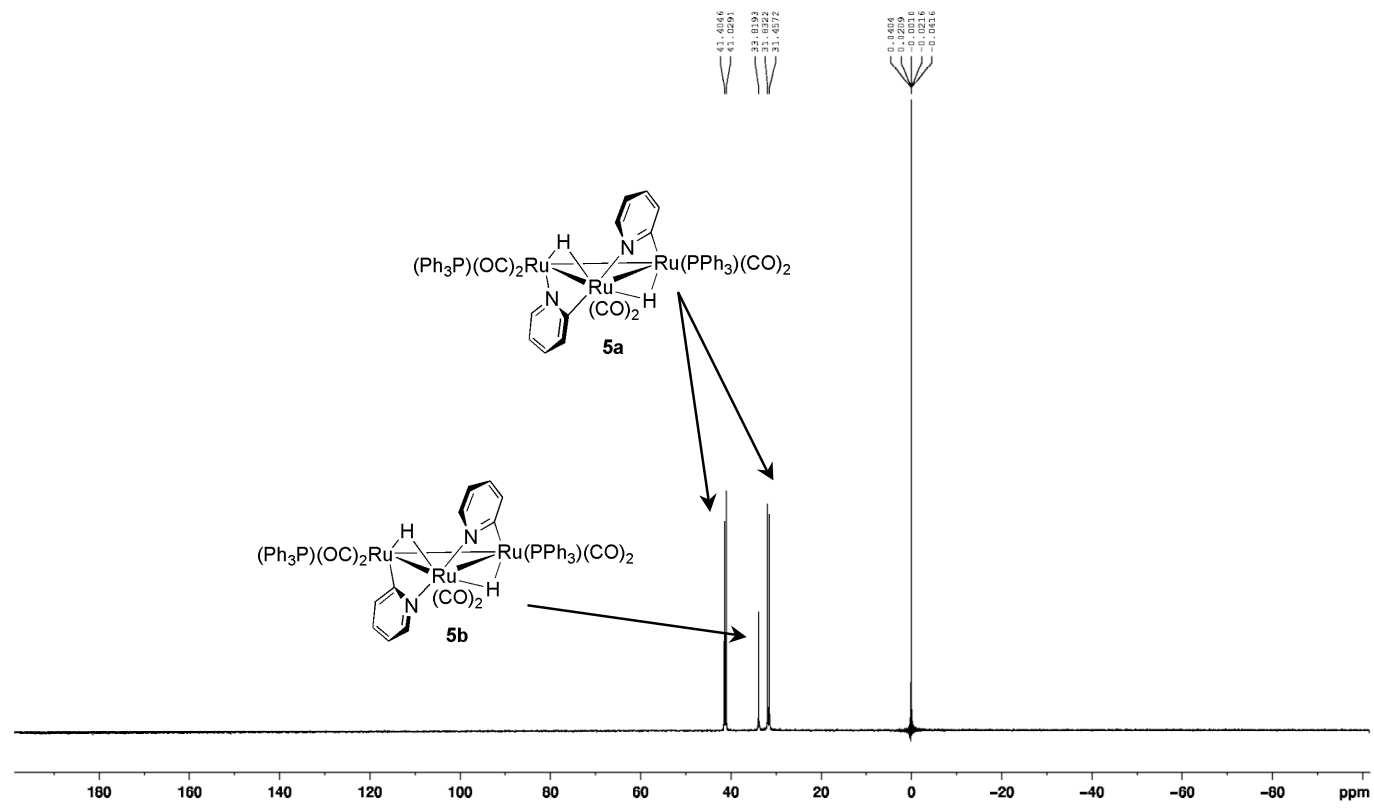

IR ( $\mathrm{KBr}$ pellet, $\left.\mathrm{cm}^{-1}\right)$ :

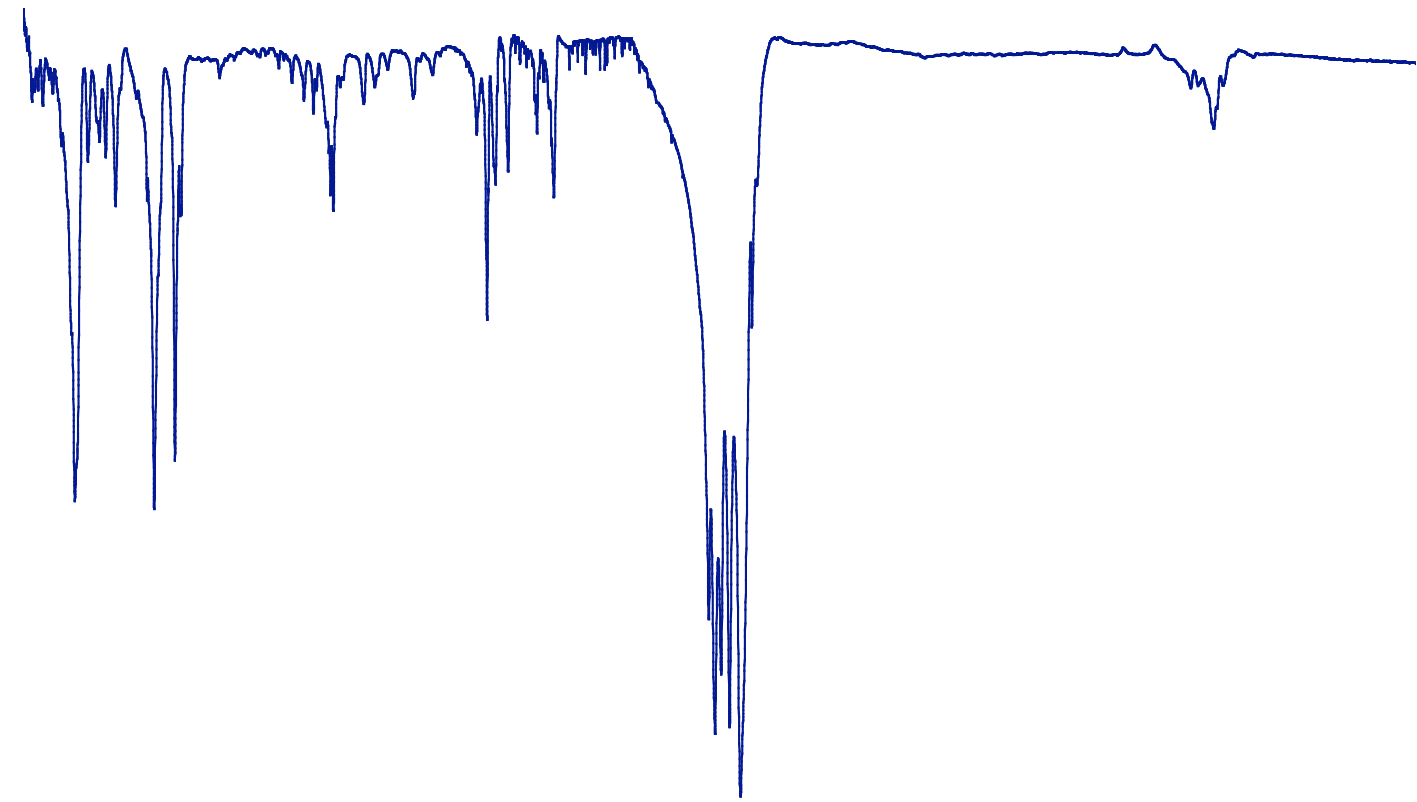

400

900

1400

1900

2400

2900

3400 


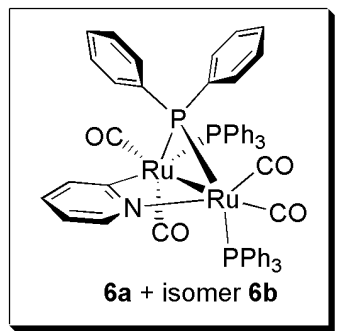

$\mathbf{R u}_{2}\left(\mu-\mathbf{P P h}_{2}\right)\left(\boldsymbol{\mu}-\mathrm{NC}_{5} \mathrm{H}_{4}\right)\left(\mathbf{P P h}_{3}\right)_{2}(\mathbf{C O})_{4} \quad(6 \mathbf{6}, 6 \mathbf{6 b})$. Dry sealable Schlenk tube was charged with complex $4(10 \mathrm{mg}, 0.01 \mathrm{mmol})$ and $\mathrm{PPh}_{3}(3 \mathrm{mg}, 0.01 \mathrm{mmol})$. The flask was evacuated and refilled with argon. Anhydrous 2-methyl-2-propanol (1 mL) was added. The flask was sealed and heated at $150^{\circ} \mathrm{C}$ for $12 \mathrm{hrs}$. After this time a clean conversion of the starting material into a new bright yellow complex was observed by TLC $\left(\mathrm{R}_{\mathrm{f}}=0.48,20 \%\right.$ ethyl acetate/hexanes). The reaction was allowed to cool to room temperature and the solvent was removed under reduced pressure to yield the product as a pale yellow solid (13 mg, $100 \%$ ). The product consists of a 1.4:1 mixture of two inseparable isomeric complexes 6 resulting from the exchange of one of the cis-CO ligands on the ruthenium center $\sigma$ bonded to pyridine as evidenced by NMR. Complexes $\mathbf{6 a}$ and $\mathbf{6 b}$ decompose during chromatography on silica and/or basic or neutral alumina. Crystallization $\left(\mathrm{CH}_{2} \mathrm{Cl}_{2} /\right.$ pentane $)$ afforded a yellow crystalline material of composition identical to that of the crude reaction product thus impeding X-ray studies and absolute structural assignments.

${ }^{1} \mathrm{H}$ NMR $\left(300 \mathrm{MHz}, \mathrm{C}_{6} \mathrm{D}_{6}\right) \delta \mathrm{ppm}: 7.90-7.70$ (m, 6H, major and $6 \mathrm{H}$, minor); 7.60-7.30 $(\mathrm{m}, 9 \mathrm{H}$, major and $9 \mathrm{H}$, minor); 7.29-7.07 $(\mathrm{m}, 1 \mathrm{H}$, major and $1 \mathrm{H}$, minor); 7.01-6.83 (m, $25 \mathrm{H}$, major and $25 \mathrm{H}$, minor); $6.68(\mathrm{~d}, \mathrm{~J}=7.9 \mathrm{~Hz}, 1 \mathrm{H}$, minor $) ; 6.48(\mathrm{~d}, \mathrm{~J}=7.5 \mathrm{~Hz}, 1 \mathrm{H}$, major); $6.13(\mathrm{~m}, 1 \mathrm{H}$, major and $1 \mathrm{H}$, minor); $5.71(\mathrm{t}, \mathrm{J}=6.4 \mathrm{~Hz}, 1 \mathrm{H}$, minor); $5.64(\mathrm{t}, \mathrm{J}=$ $6.5 \mathrm{~Hz}, 1 \mathrm{H}$, major).

${ }^{13} \mathrm{C}$ NMR $\left(75 \mathrm{MHz}, \mathrm{CDCl}_{3}\right) \delta$ ppm: observed complexity due to P-C splitting and presence of two isomers in the sample; definitive assignments could not be made with reasonable certainty.

${ }^{31} \mathrm{P}$ NMR (121 MHz, $\left.\mathrm{CDCl}_{3}\right) \delta \mathrm{ppm:} 136.2\left(\mathrm{dd}, \mathrm{J}_{1}=19.7 \mathrm{~Hz}, \mathrm{~J}_{2}=176.5 \mathrm{~Hz}, 1 \mathrm{P}, \mathrm{PPh}_{2}\right.$, major); $134.3\left(\mathrm{dd}, \mathrm{J}_{1}=21.4 \mathrm{~Hz}, \mathrm{~J}_{2}=170.1 \mathrm{~Hz}, 1 \mathrm{P}, \mathrm{PPh}_{2}\right.$, minor); 45.0 (d, J = 170.2 Hz, $1 \mathrm{P}$, trans $-\mathrm{PPh}_{3}$, minor); $42.9\left(\mathrm{~d}, \mathrm{~J}=176.0 \mathrm{~Hz}, 1 \mathrm{P}\right.$, trans $-\mathrm{PPh}_{3}$, major); 37.7 (d, $\mathrm{J}=20.1$ $\mathrm{Hz}, 1 \mathrm{P}$, cis- $\mathrm{PPh}_{3}$, major); 27.7 (d, J $=21.4 \mathrm{~Hz}, 1 \mathrm{P}$, cis $-\mathrm{PPh}_{3}$, minor).

MS (FAB ${ }^{+}$) Calcd for $\mathrm{C}_{57} \mathrm{H}_{44} \mathrm{NO}_{4} \mathrm{P}_{3} \mathrm{Ru}_{2}: \mathrm{m} / \mathrm{z}=1103.06$. Found $\mathrm{m} / \mathrm{z}=1103.09$.

IR (KBr pellet, $\left.\mathrm{cm}^{-1}\right): 3051,1991,1964,1918,1578,1480,1432,1089,739,694,561$, 520.

Anal. Calcd for $\mathrm{C}_{57} \mathrm{H}_{44} \mathrm{NO}_{4} \mathrm{P}_{3} \mathrm{Ru}_{2}$ : C, 62.12; H, 4.02; N, 1.27. Found: C, 62.57; H, 4.25; $\mathrm{N}, 1.35$. 
${ }^{1} \mathrm{H}$ NMR (300 MHz, $\mathrm{C}_{6} \mathrm{D}_{6}$ ):

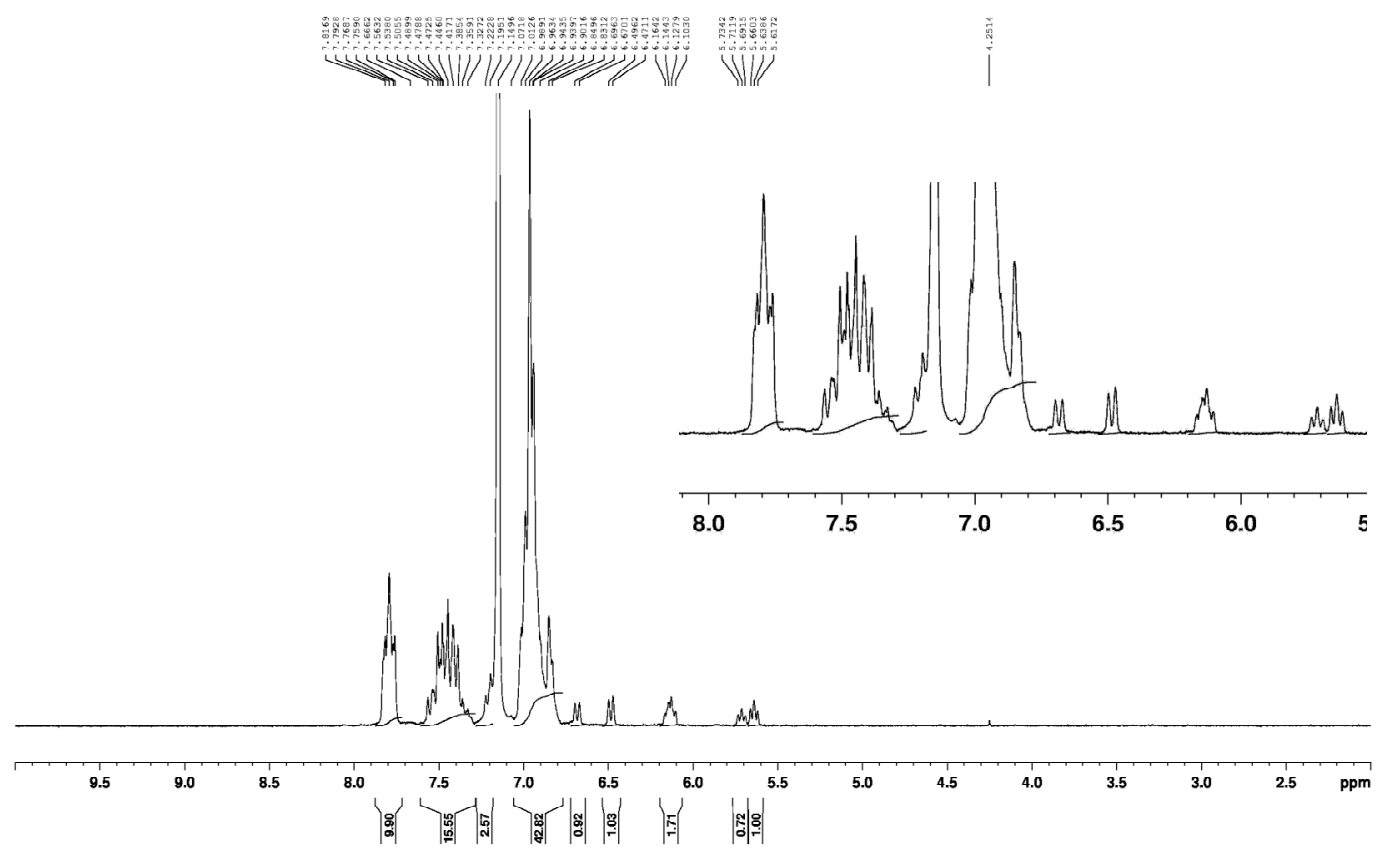

${ }^{13} \mathrm{C}$ NMR (75 MHz, $\left.\mathrm{CDCl}_{3}\right)$ :

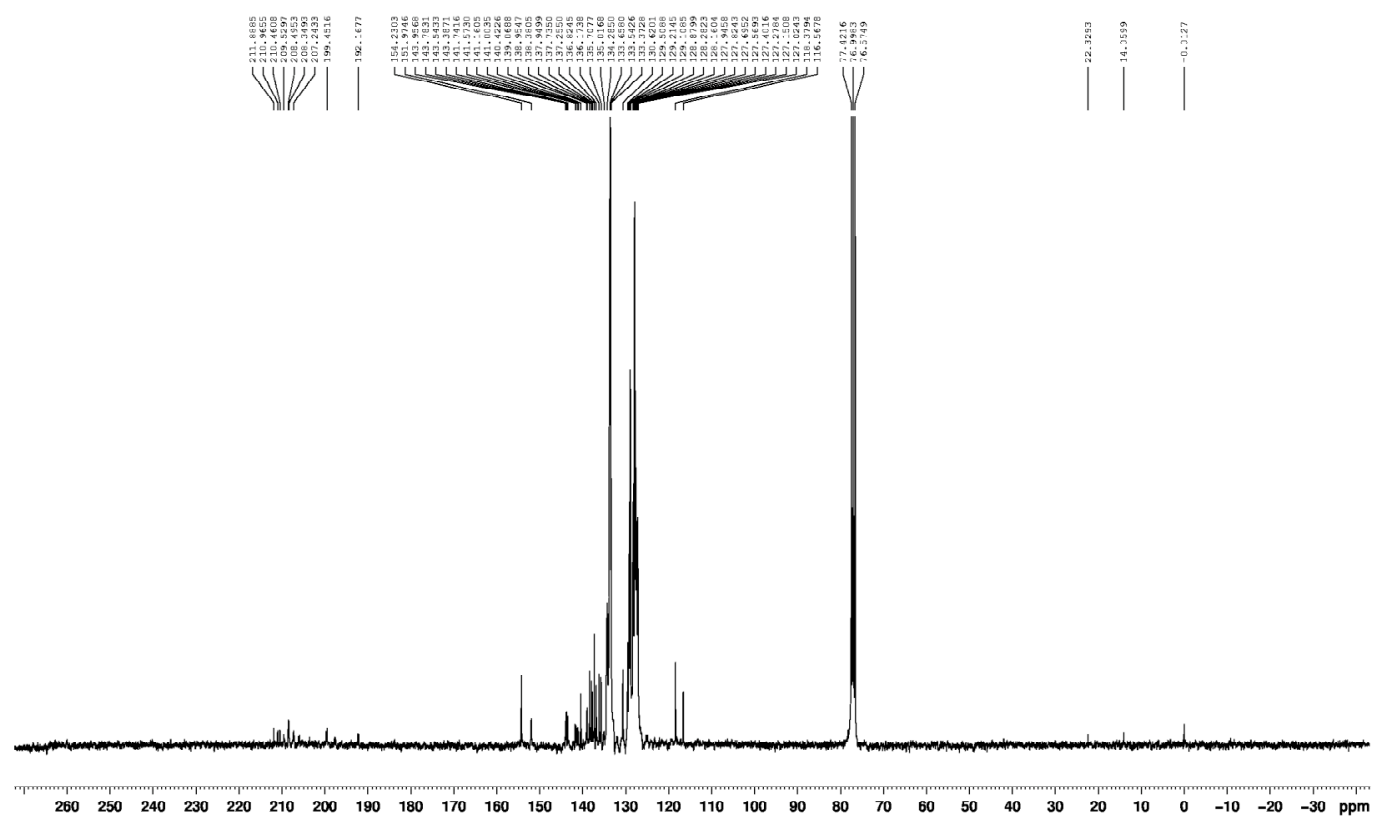


${ }^{31} \mathrm{P}$ NMR (121 MHz, $\left.\mathrm{CDCl}_{3}\right)$ :

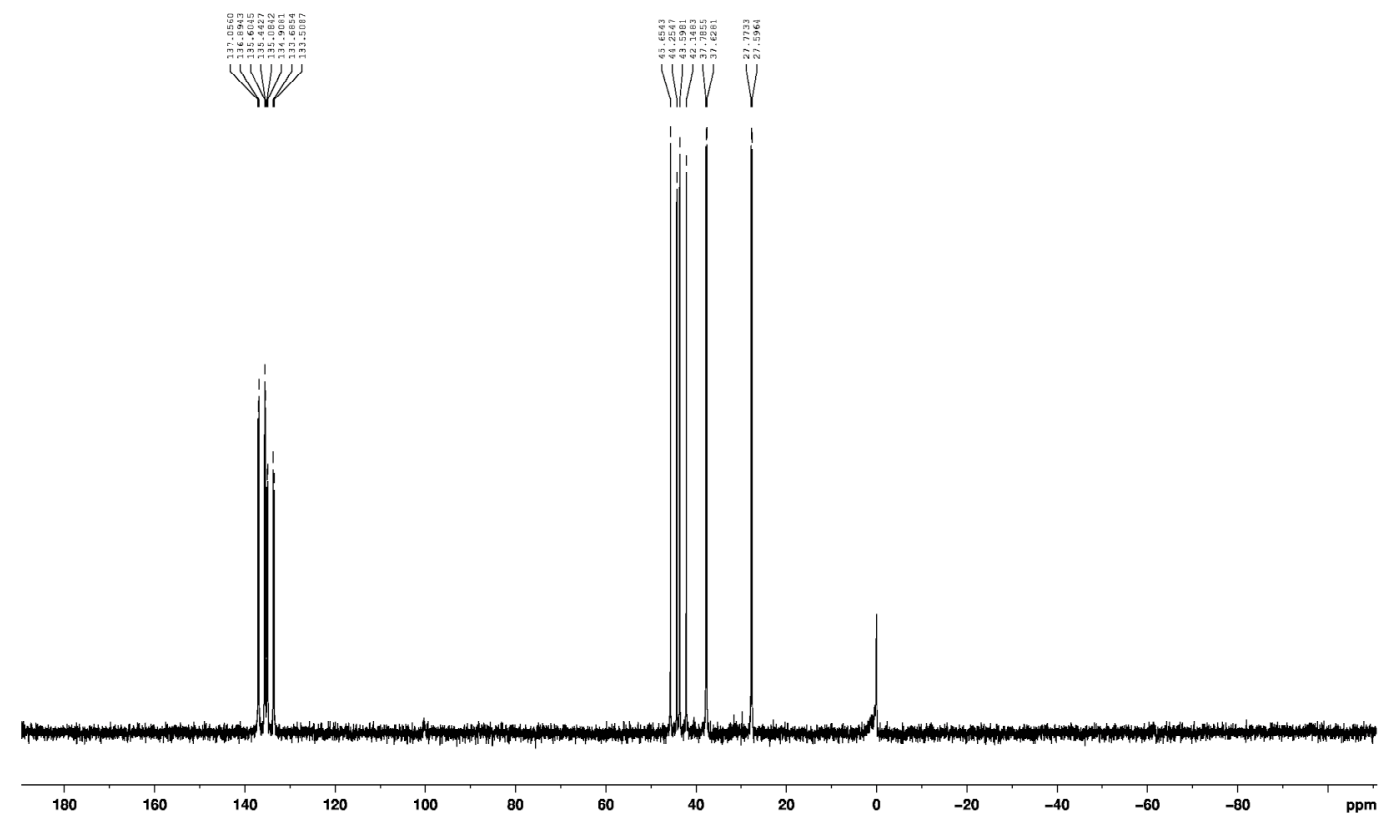

IR ( $\mathrm{KBr}$ pellet, $\left.\mathrm{cm}^{-1}\right)$ :

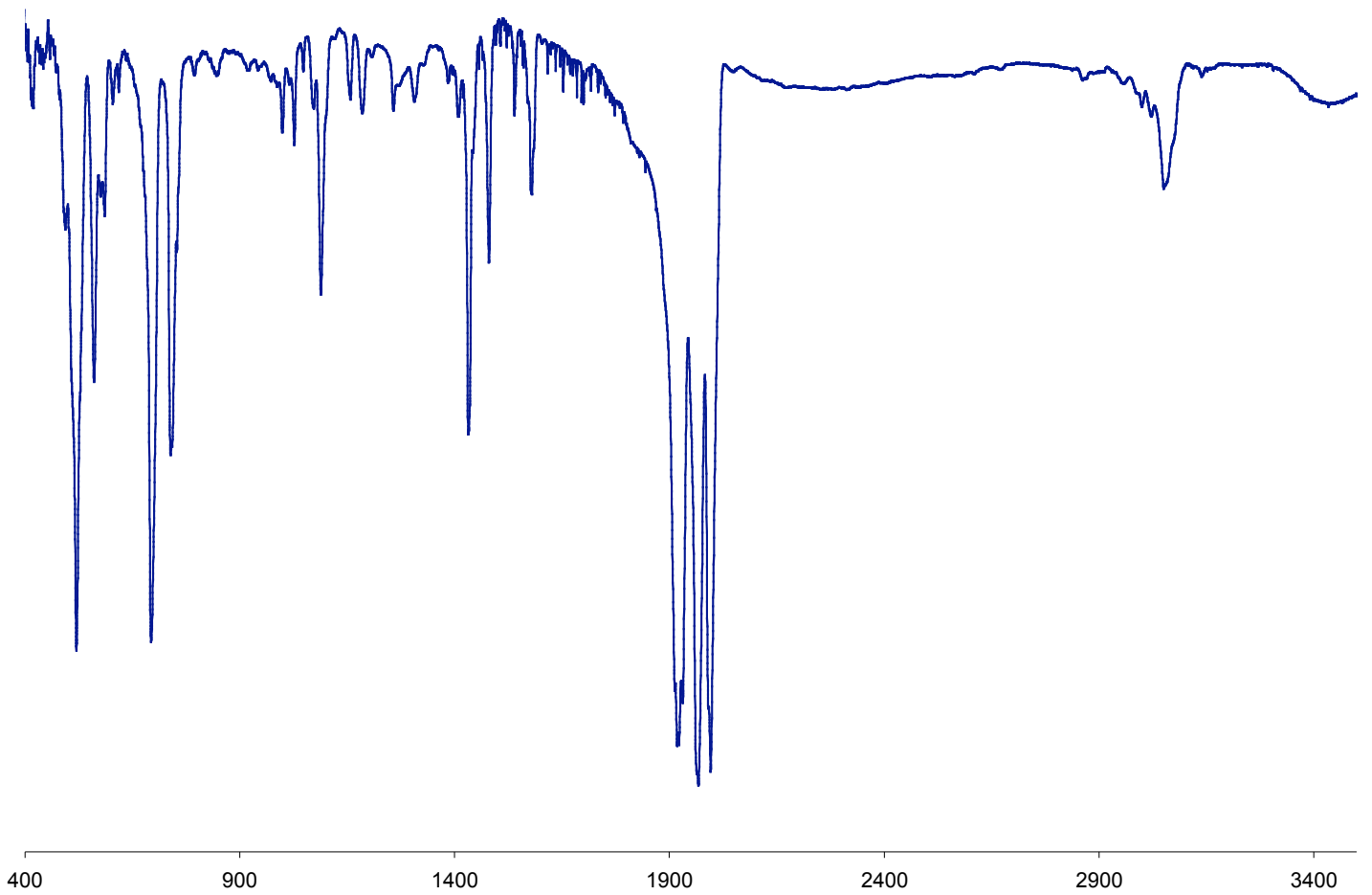




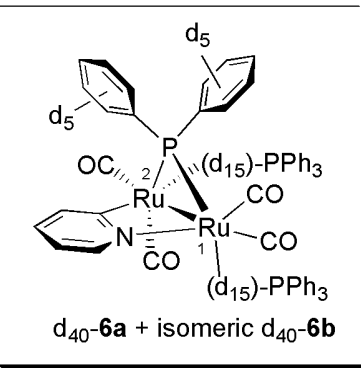

$\mathrm{Ru}_{2}\left(\mu-\mathrm{PPh}_{2}-d_{10}\right)\left(\mu-\mathrm{NC}_{5} \mathrm{H}_{4}\right)\left(\mathrm{PPh}_{3}-d_{15}\right)_{2}(\mathrm{CO})_{4} \quad\left(d_{40}-6 \mathrm{a}, d_{40}-6 \mathrm{~b}\right)$. Complexes $\boldsymbol{d}_{40}-\mathbf{6}$ were prepared from complex $\boldsymbol{d}_{25} \mathbf{4}(20 \mathrm{mg}, 0.02$ $\mathrm{mmol})$ and $\mathrm{PPh}_{3}-d_{15}(6.2 \mathrm{mg}, 0.02 \mathrm{mmol})$ in a fashion similar to that for preparation of complexes 6 . After completion of the reaction and removal of the solvent the product was obtained as a pale yellow solid (26 mg, 100\%). ${ }^{1} \mathrm{H}$ NMR data were analogous to those of complexes $\mathbf{6}$. The ratio of complexes $\boldsymbol{d}_{40^{-}} \mathbf{6 a}$ and $\boldsymbol{d}_{40^{-}}$ $\mathbf{6 b}$ in the product was identical to that observed for complexes $\mathbf{6}$. NMR analysis indicated a partial D-H exchange into the phosphine and phosphide phenyl groups.

${ }^{1} \mathrm{H}$ NMR (300 MHz, $\left.\mathrm{C}_{6} \mathrm{D}_{6}\right)$ :

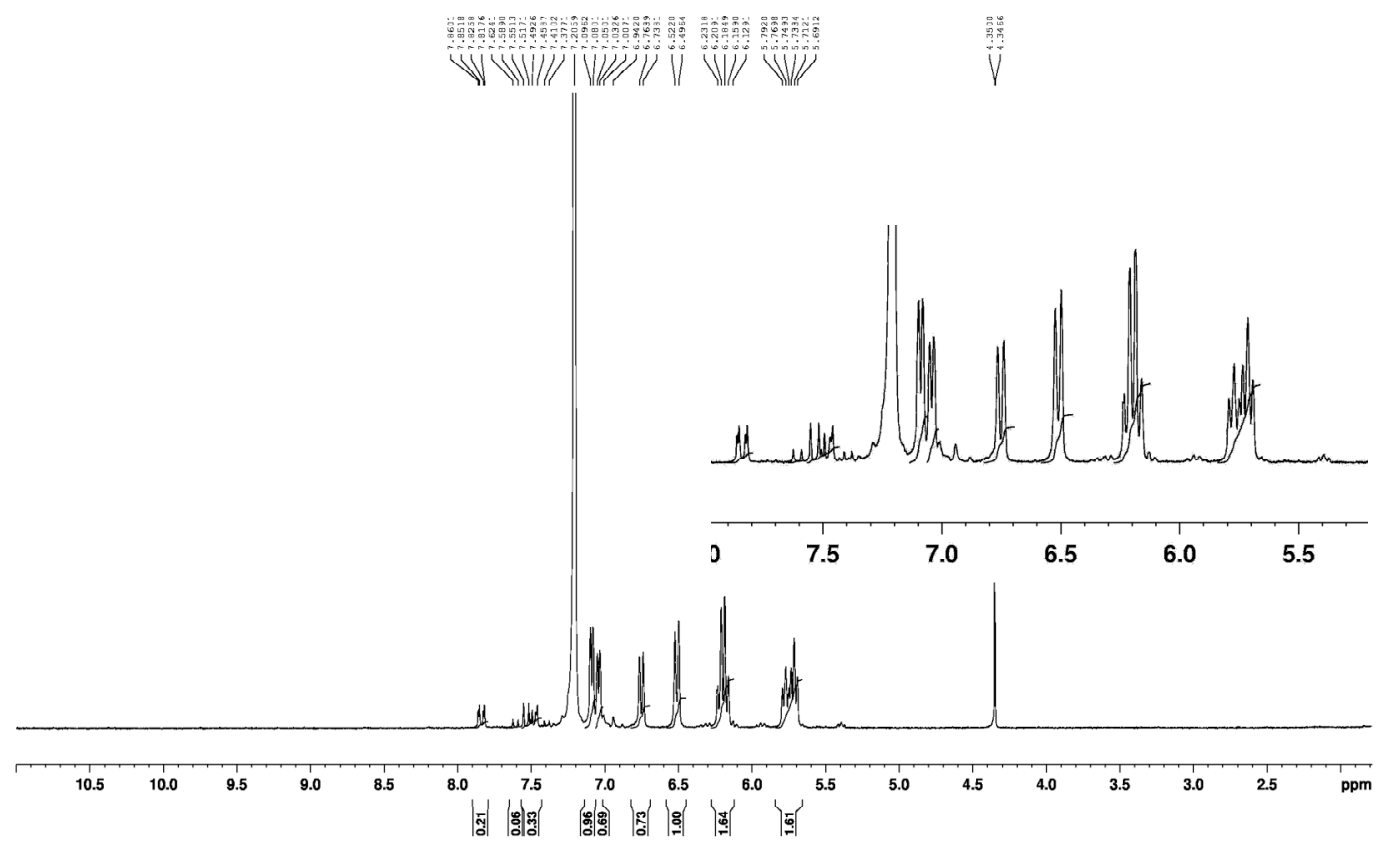




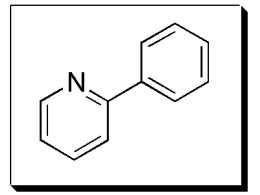

Coupling of pyridine with iodobenzene. Pressure vessel containing a stirring bar was charged with $\mathrm{Cs}_{2} \mathrm{CO}_{3}(330 \mathrm{mg}, 0.94 \mathrm{mmol})$ and fitted with a screw cap equipped with PTFE/silicon liner. Vacuum was applied and the vessel was heated at $150^{\circ} \mathrm{C}$ for $2 \mathrm{hrs}$. After this time the vessel was filled with argon and allowed to cool to room temperature. $\mathrm{Ru}_{3}(\mathrm{CO})_{12}(10 \mathrm{mg}, 0.016$ $\mathrm{mmol})$ and $\mathrm{PPh}_{3}(8.2 \mathrm{mg}, 0.032 \mathrm{mmol})$ were added. The vessel was closed and evacuated and refilled with argon. This was repeated three times. Anhydrous 2-methyl-2-propanol $(1.5 \mathrm{~mL})$ was added through septum, followed by freshly distilled pyridine $(63 \mu \mathrm{L}, 0.780$ mmol) and iodobenzene $(88 \mu \mathrm{L}, 0.780 \mathrm{mmol})$. The mixture was cooled to $-78^{\circ} \mathrm{C}$, evacuated and warmed up to room temperature. This was repeated three times. Finally, the reaction vessel was filled with argon and the reaction was warmed up to $100^{\circ} \mathrm{C}$. After $0.5 \mathrm{hr}$ at this temperature, the temperature was increased to $110^{\circ} \mathrm{C}$. After $0.5 \mathrm{hr}$ at this temperature the reaction temperature was brought to $150^{\circ} \mathrm{C}$ and stirred at this temperature for $17 \mathrm{hrs}$. Quick heating to the reaction temperature leads to significantly lower yields (28\%) or may stop the reaction altogether. After this time the reaction mixture was allowed to cool to room temperature and filtered through Celite. TLC analysis showed the formation of a sole product $\left(\mathrm{R}_{\mathrm{f}}=0.45,20 \%\right.$ ethyl acetate/hexanes $)$. The filtrate was concentrated and chromatographed on silica $\left(100 \% \mathrm{CH}_{2} \mathrm{Cl}_{2}\right)$ to give $45 \mathrm{mg}$ of 2phenylpyridne as colorless oil (37\%). ${ }^{1} \mathrm{H}$ NMR spectrum was identical to that of commercially available 2-phenylpyridine.

${ }^{1} \mathrm{H}$ NMR (300 MHz, $\left.\mathrm{C}_{6} \mathrm{D}_{6}\right)$ :

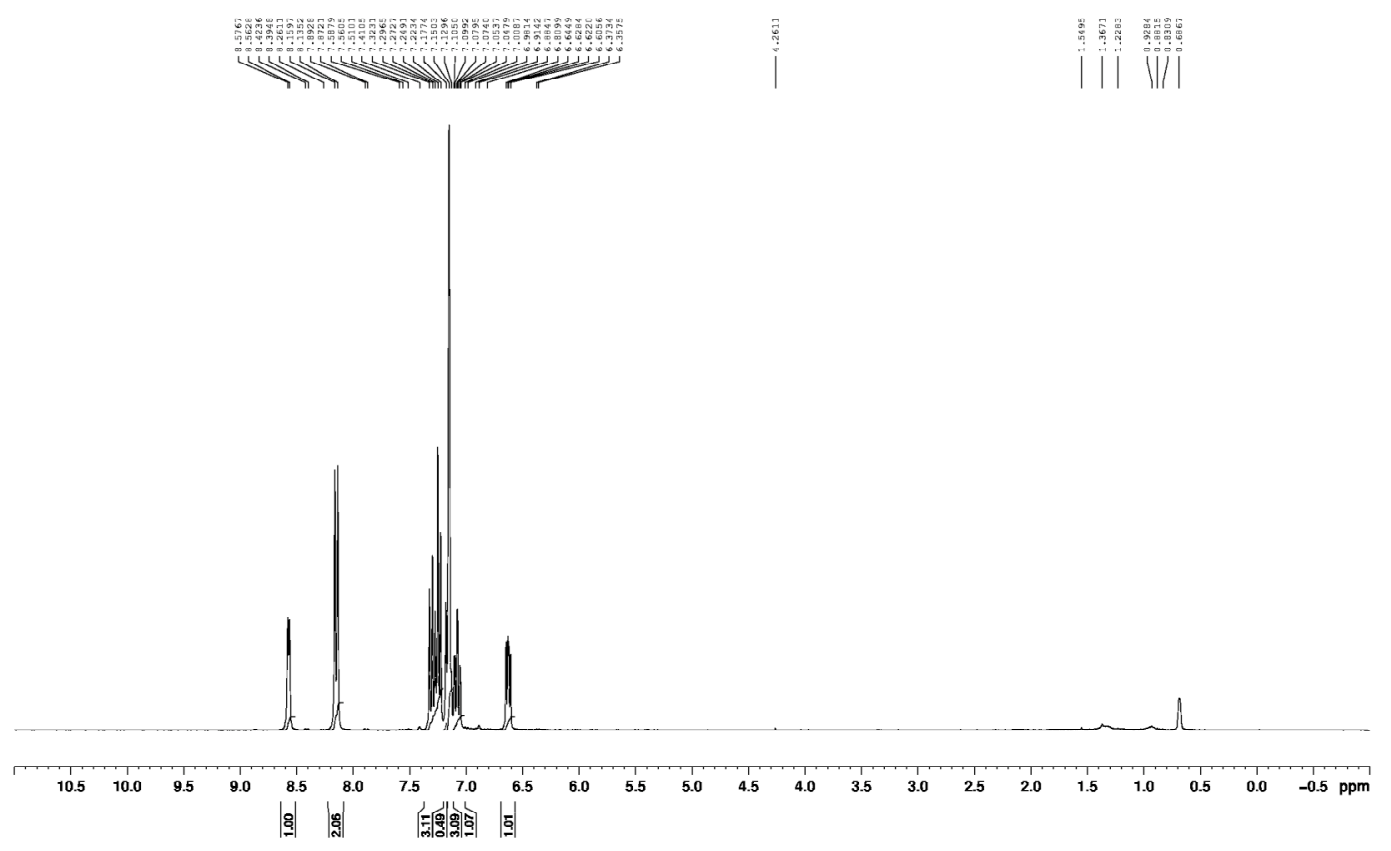

This exact same procedure was followed in the coupling reactions of pyridine and iodobenzene catalyzed by compexes 1-6. The rate of heating to $150^{\circ} \mathrm{C}$ plays a crucial role in all the instances involving a prior formation of a dimeric ruthenium species, i.e. when complexes 1, 2, and $\mathbf{3}$ are employed. 
Labeling experiment: coupling of pyridine and iodobenzene catalyzed by $\boldsymbol{d}_{40^{-}} \mathbf{6}$. The procedure was analogous to the one described above for the coupling of pyridine and iodobenzene catalyzed by $\mathrm{Ru}_{3}(\mathrm{CO})_{12} / \mathrm{PPh}_{3}$ catalytic system. Complex $\boldsymbol{d}_{40^{-}} \mathbf{6}(24.5 \mathrm{mg}$, $0.022 \mathrm{mmol}$ ) was employed and the reaction was stopped after $6 \mathrm{hrs}$. The crude product after filtration and removal of solvent under reduced pressure was scrutinized for incorporation of unlabeled phenyl groups into the catalyst. ${ }^{1} \mathrm{H}$ NMR analysis showed no significant phenyl exchange, as evidenced by the lack of proton signals in the 8.00-7.60 and 7.15-7.00 ppm regions (highlighted in red squares in ${ }^{1} \mathrm{H}$ NMR spectrum below). The crude product was then chromatographed $\left(100 \% \mathrm{CH}_{2} \mathrm{Cl}_{2}\right)$ to give $9 \mathrm{mg}(8 \%)$ of the product. No incorporation of $d_{5}$-phenyl groups into the product was observed by NMR spectroscopy.

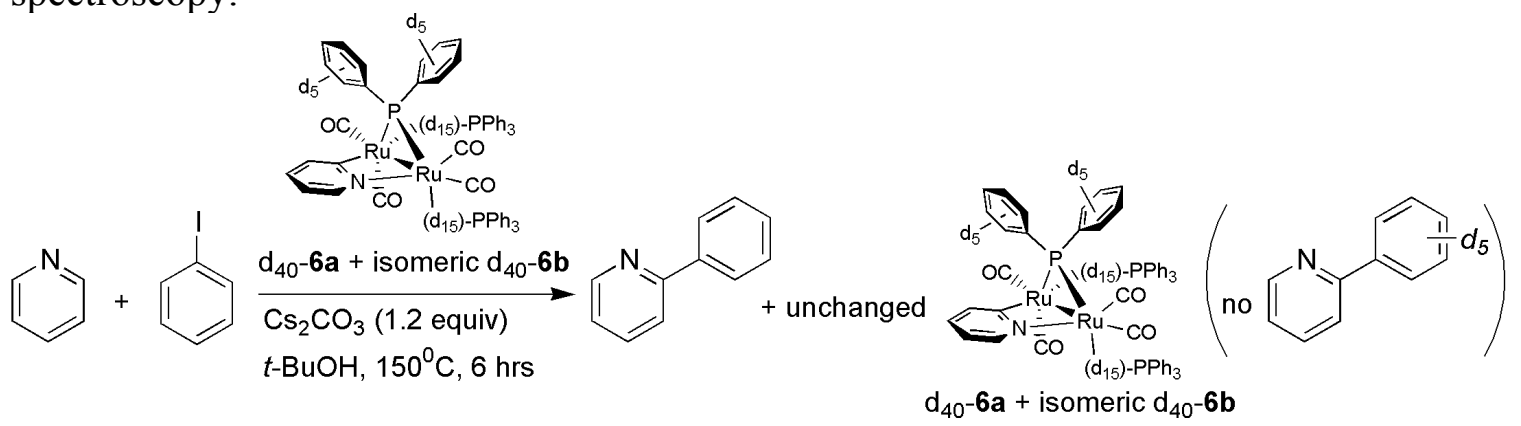

${ }^{1} \mathrm{H}$ NMR $\left(300 \mathrm{MHz}, \mathrm{C}_{6} \mathrm{D}_{6}\right)$ of crude reaction product:

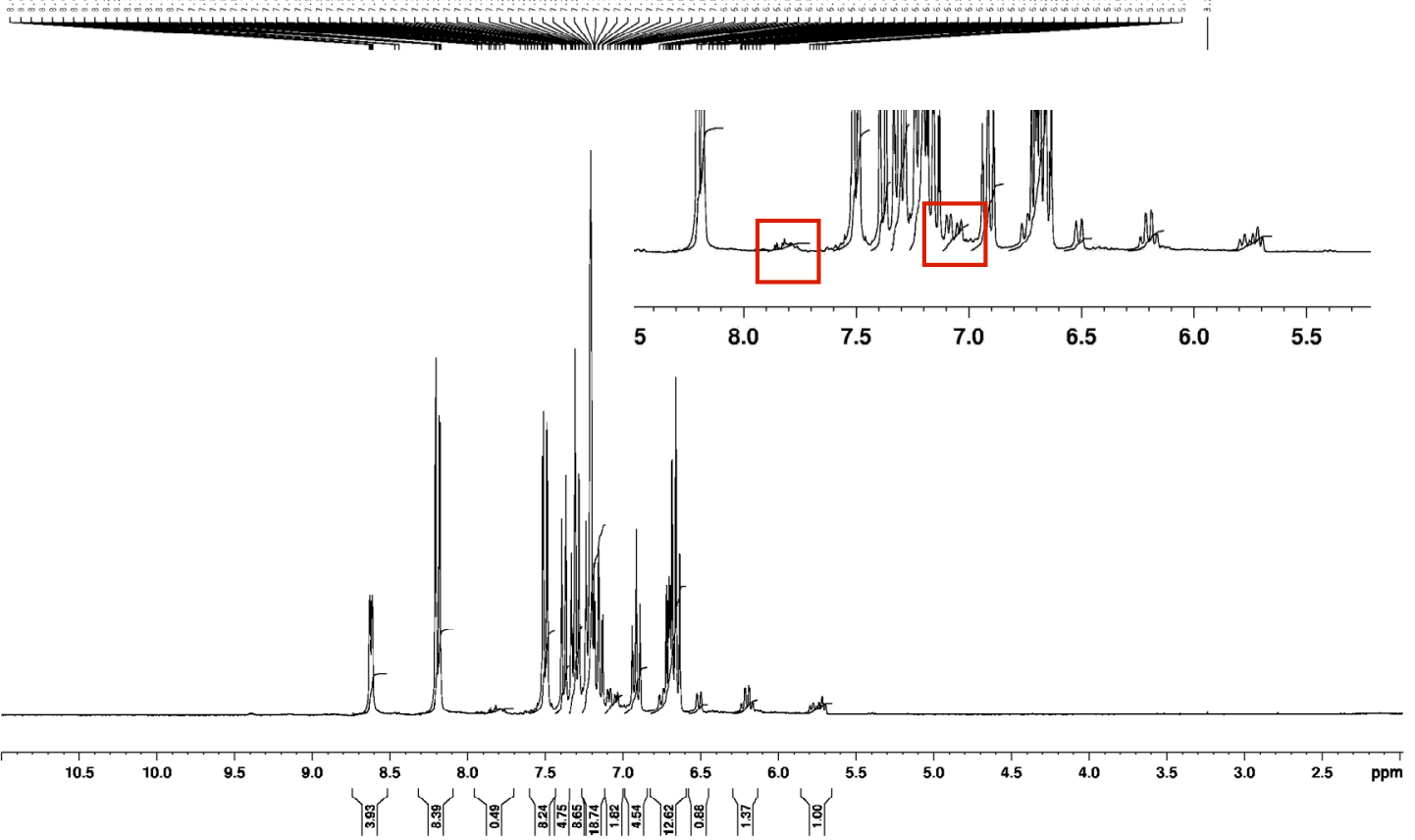


Ortep diagram for $\mathbf{R u}_{3}(\mu-\mathbf{H})\left(\mu-\mathrm{NC}_{5} \mathbf{H}_{4}\right)\left(\mathbf{P P h}_{3}\right)(\mathbf{C O})_{9}(2)$.

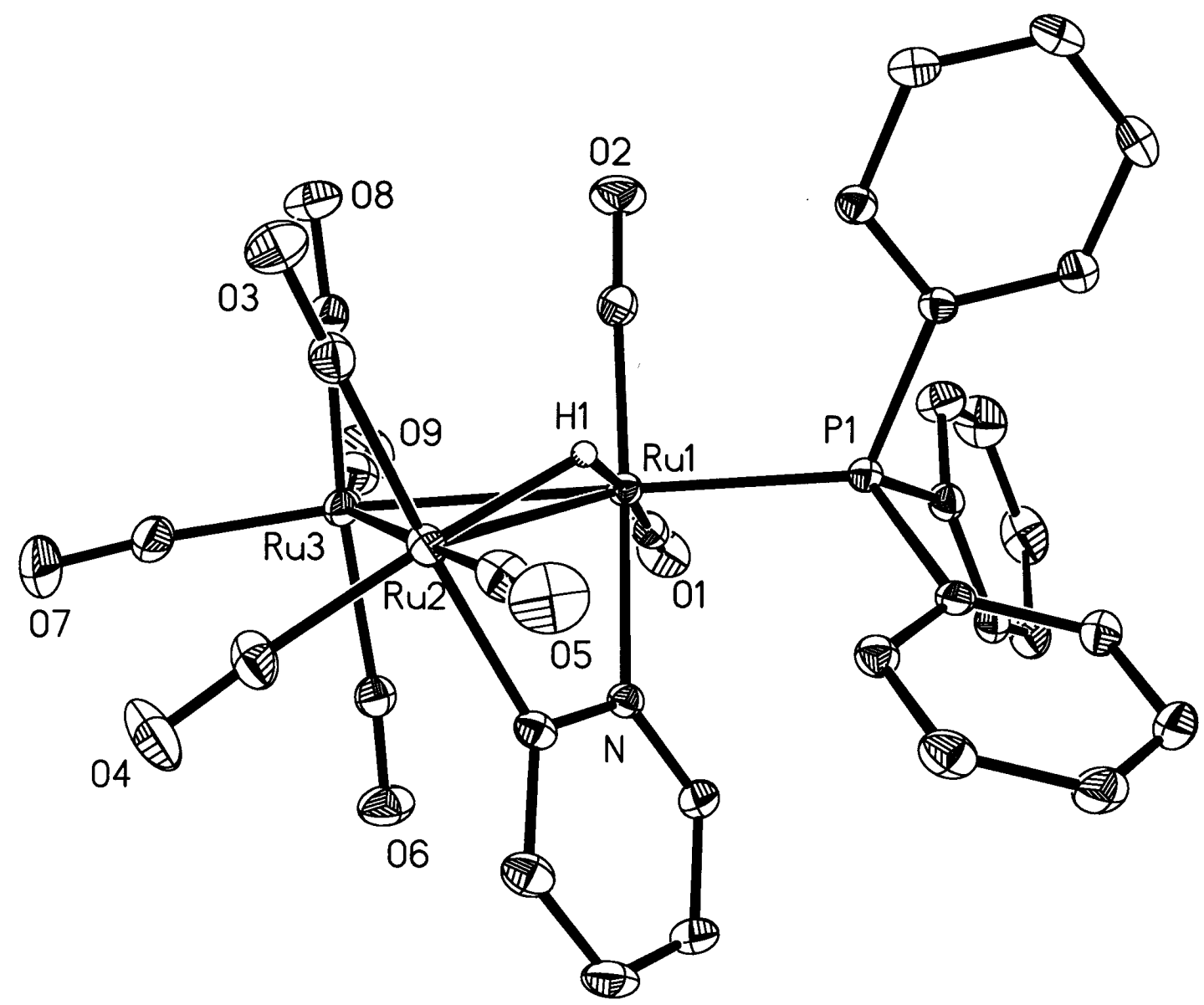


Table 1. Crystal data and structure refinement for $\mathbf{R u}_{3}(\mu-\mathbf{H})\left(\mu-\mathbf{N C}_{5} \mathbf{H}_{4}\right)\left(\mathbf{P P h}_{3}\right)(\mathbf{C O})_{9}(2)$.

Identification code

Empirical formula

Formula weight

Temperature

Wavelength

Crystal system

Space group

Unit cell dimensions

Volume, Z

Density (calculated)

Absorption coefficient

F (000)

Crystal size

$\theta$ range for data collection

Limiting indices

Reflections collected

Independent reflections

Completeness to $\theta=28.28^{\circ}$

Absorption correction

Max. and min. transmission

Refinement method

Data / restraints / parameters

Goodness-of-fit on $\mathrm{F}^{2}$

Final $R$ indices $[\mathrm{I}>2 \sigma(\mathrm{I})]$

$\mathrm{R}$ indices (all data)

Extinction coefficient

Largest diff. peak and hole ru3hs 10

$\mathrm{C}_{32} \mathrm{H}_{20} \mathrm{NO}_{9} \mathrm{PRu}_{3}$

896.67

243(2) K

$0.71073 \AA$

Monoclinic

$\mathrm{P} 2{ }_{1} / \mathrm{n}$

$a=9.3834$ (6) $\AA$ alpha $=90^{\circ}$

$b=24.0014$ (16) $\AA$ beta $=93.1040(10)^{\circ}$

$c=14.5305$ (9) $\AA$ gamma $=90^{\circ}$

3267.7 (4) $\AA^{3}, 4$

$1.823 \mathrm{Mg} / \mathrm{m}^{3}$

$1.472 \mathrm{~mm}^{-1}$

1752

$0.30 \times 0.10 \times 0.10 \mathrm{~mm}$

1.64 to $28.28^{\circ}$

$-12 \leq \mathrm{h} \leq 12,-31 \leq \mathrm{k} \leq 30,-7 \leq 1 \leq 19$

22231

$7484\left(\mathrm{R}_{\mathrm{int}}=0.0310\right)$

$92.2 \%$

SADABS

0.8668 and 0.6665

Full-matrix least-squares on $\mathrm{F}^{2}$

7484 / 0 / 420

1.080

$\mathrm{R} 1=0.0284, \mathrm{wR} 2=0.0453$

$\mathrm{R} 1=0.0465, \mathrm{wR} 2=0.0480$

$0.00010(3)$

0.377 and $-0.537 \mathrm{e}^{-3}$

Table 2. Bond lengths $[\AA]$ and angles $\left[^{\circ}\right]$ for $\mathrm{Ru}_{3}(\mu-\mathrm{H})\left(\mu-\mathrm{NC}_{5} \mathrm{H}_{4}\right)\left(\mathrm{PPh}_{3}\right)(\mathrm{CO})_{9}$. 
Table 2. Bond lengths $[\AA]$ and angles $\left[^{\circ}\right]$ for $\mathbf{R u}_{3}(\mu-\mathbf{H})\left(\mu-\mathbf{N C}_{5} \mathbf{H}_{4}\right)\left(\mathbf{P P h}_{3}\right)(\mathbf{C O})_{9}(\mathbf{2})$.

\begin{tabular}{|c|c|c|c|}
\hline $\mathrm{Ru}(1)-\mathrm{H}(1)$ & $1.80(2)$ & $\mathrm{Ru}(1)-\mathrm{C}(2)$ & $1.876(3)$ \\
\hline $\mathrm{Ru}(1)-\mathrm{C}(1)$ & $1.881(3)$ & $\mathrm{Ru}(1)-\mathrm{N}$ & $2.115(2)$ \\
\hline $\mathrm{Ru}(1)-\mathrm{P}(1)$ & $2.3798(7)$ & $\mathrm{Ru}(1)-\mathrm{Ru}(3)$ & $2.8496(3)$ \\
\hline $\mathrm{Ru}(1)-\mathrm{Ru}(2)$ & $2.9214(3)$ & $\mathrm{Ru}(2)-\mathrm{H}(1)$ & $1.74(2)$ \\
\hline $\mathrm{Ru}(2)-\mathrm{C}(4)$ & $1.892(3)$ & $\mathrm{Ru}(2)-\mathrm{C}(5)$ & $1.899(3)$ \\
\hline $\mathrm{Ru}(2)-\mathrm{C}(3)$ & $1.954(3)$ & $\mathrm{Ru}(2)-\mathrm{C}(11)$ & $2.099(2)$ \\
\hline $\mathrm{Ru}(2)-\mathrm{Ru}(3)$ & $2.8693(3)$ & $\mathrm{Ru}(3)-\mathrm{C}(7)$ & $1.914(3)$ \\
\hline $\mathrm{Ru}(3)-\mathrm{C}(9)$ & $1.921(4)$ & $\mathrm{Ru}(3)-\mathrm{C}(8)$ & $1.935(3)$ \\
\hline $\mathrm{Ru}(3)-\mathrm{C}(6)$ & $1.935(3)$ & $P(1)-C(41)$ & $1.822(2)$ \\
\hline $\mathrm{P}(1)-\mathrm{C}(51)$ & $1.834(3)$ & $\mathrm{P}(1)-\mathrm{C}(21)$ & $1.841(3)$ \\
\hline $\mathrm{O}(1)-\mathrm{C}(1)$ & $1.141(3)$ & $\mathrm{O}(2)-\mathrm{C}(2)$ & $1.146(3)$ \\
\hline $\mathrm{O}(3)-\mathrm{C}(3)$ & $1.141(3)$ & $\mathrm{O}(4)-\mathrm{C}(4)$ & $1.143(3)$ \\
\hline $\mathrm{O}(5)-\mathrm{C}(5)$ & $1.140(3)$ & $\mathrm{O}(6)-\mathrm{C}(6)$ & $1.137(3)$ \\
\hline $\mathrm{O}(7)-\mathrm{C}(7)$ & $1.142(4)$ & $\mathrm{O}(8)-\mathrm{C}(8)$ & $1.136(3)$ \\
\hline $\mathrm{O}(9)-\mathrm{C}(9)$ & $1.140(4)$ & $\mathrm{N}-\mathrm{C}(15)$ & $1.348(3)$ \\
\hline $\mathrm{N}-\mathrm{C}(11)$ & $1.354(3)$ & $\mathrm{C}(11)-\mathrm{C}(12)$ & $1.391(4)$ \\
\hline $\mathrm{C}(12)-\mathrm{C}(13)$ & $1.386(4)$ & $\mathrm{C}(13)-\mathrm{C}(14)$ & $1.362(4)$ \\
\hline $\mathrm{C}(14)-\mathrm{C}(15)$ & $1.360(4)$ & $\mathrm{C}(21)-\mathrm{C}(26)$ & $1.390(3)$ \\
\hline $\mathrm{C}(21)-\mathrm{C}(22)$ & $1.393(3)$ & $\mathrm{C}(22)-\mathrm{C}(23)$ & $1.375(4)$ \\
\hline $\mathrm{C}(23)-\mathrm{C}(24)$ & $1.374(4)$ & $\mathrm{C}(24)-\mathrm{C}(25)$ & $1.371(4)$ \\
\hline $\mathrm{C}(25)-\mathrm{C}(26)$ & $1.382(4)$ & $\mathrm{C}(41)-\mathrm{C}(42)$ & $1.389(4)$ \\
\hline $\mathrm{C}(41)-\mathrm{C}(46)$ & $1.392(3)$ & $\mathrm{C}(42)-\mathrm{C}(43)$ & $1.370(4)$ \\
\hline $\mathrm{C}(43)-\mathrm{C}(44)$ & $1.377(4)$ & $\mathrm{C}(44)-\mathrm{C}(45)$ & $1.363(4)$ \\
\hline $\mathrm{C}(45)-\mathrm{C}(46)$ & $1.380(4)$ & $\mathrm{C}(51)-\mathrm{C}(52)$ & $1.383(3)$ \\
\hline $\mathrm{C}(51)-\mathrm{C}(56)$ & $1.393(4)$ & $\mathrm{C}(52)-\mathrm{C}(53)$ & $1.395(4)$ \\
\hline $\mathrm{C}(53)-\mathrm{C}(54)$ & $1.368(4)$ & $\mathrm{C}(54)-\mathrm{C}(55)$ & $1.378(4)$ \\
\hline$C(55)-C(56)$ & $1.370(4)$ & & \\
\hline $\mathrm{H}(1)-\mathrm{Ru}(1)-\mathrm{C}(2)$ & $91.8(7)$ & $\mathrm{H}(1)-\mathrm{Ru}(1)-\mathrm{C}(1)$ & $175.3(8)$ \\
\hline $\mathrm{C}(2)-\mathrm{Ru}(1)-\mathrm{C}(1)$ & $90.43(12)$ & $\mathrm{H}(1)-\mathrm{Ru}(1)-\mathrm{N}$ & $85.5(7)$ \\
\hline $\mathrm{C}(2)-\mathrm{Ru}(1)-\mathrm{N}$ & $176.89(10)$ & $\mathrm{C}(1)-\mathrm{Ru}(1)-\mathrm{N}$ & $92.20(10)$ \\
\hline $\mathrm{H}(1)-\mathrm{Ru}(1)-\mathrm{P}(1)$ & $89.8(8)$ & $\mathrm{C}(2)-\mathrm{Ru}(1)-\mathrm{P}(1)$ & $91.51(9)$ \\
\hline $\mathrm{C}(1)-\mathrm{Ru}(1)-\mathrm{P}(1)$ & $94.29(9)$ & N-Ru(1)-P(1) & $89.95(6)$ \\
\hline $\mathrm{H}(1)-\mathrm{Ru}(1)-\mathrm{Ru}(3)$ & $87.6(8)$ & $\mathrm{C}(2)-\mathrm{Ru}(1)-\mathrm{Ru}(3)$ & $89.42(8)$ \\
\hline $\mathrm{C}(1)-\mathrm{Ru}(1)-\mathrm{Ru}(3)$ & $88.24(8)$ & N-Ru(1)-Ru(3) & $89.00(5)$ \\
\hline $\mathrm{P}(1)-\mathrm{Ru}(1)-\mathrm{Ru}(3)$ & 177.301(19) & $\mathrm{H}(1)-\mathrm{Ru}(1)-\mathrm{Ru}(2)$ & $33.9(8)$ \\
\hline $\mathrm{C}(2)-\mathrm{Ru}(1)-\mathrm{Ru}(2)$ & $108.55(8)$ & $\mathrm{C}(1)-\mathrm{Ru}(1)-\mathrm{Ru}(2)$ & $141.38(8)$ \\
\hline $\mathrm{N}-\mathrm{Ru}(1)-\mathrm{Ru}(2)$ & $68.34(5)$ & $\mathrm{P}(1)-\mathrm{Ru}(1)-\mathrm{Ru}(2)$ & $117.690(18)$ \\
\hline $\mathrm{Ru}(3)-\mathrm{Ru}(1)-\mathrm{Ru}(2)$ & $59.612(8)$ & $\mathrm{H}(1)-\mathrm{Ru}(2)-\mathrm{C}(4)$ & $173.0(7)$ \\
\hline $\mathrm{H}(1)-\mathrm{Ru}(2)-\mathrm{C}(5)$ & $88.7(8)$ & $C(4)-R u(2)-C(5)$ & $95.79(14)$ \\
\hline $\mathrm{H}(1)-\mathrm{Ru}(2)-\mathrm{C}(3)$ & $89.8(7)$ & $\mathrm{C}(4)-\mathrm{Ru}(2)-\mathrm{C}(3)$ & $95.26(13)$ \\
\hline $\mathrm{C}(5)-\mathrm{Ru}(2)-\mathrm{C}(3)$ & $93.07(12)$ & $\mathrm{H}(1)-\mathrm{Ru}(2)-\mathrm{C}(11)$ & $85.8(7)$ \\
\hline $\mathrm{C}(4)-\mathrm{Ru}(2)-\mathrm{C}(11)$ & $88.97(11)$ & $\mathrm{C}(5)-\mathrm{Ru}(2)-\mathrm{C}(11)$ & $88.49(11)$ \\
\hline
\end{tabular}




\begin{tabular}{|c|c|c|c|}
\hline$C(3)-R u(2)-C(11)$ & $175.31(11)$ & $\mathrm{H}(1)-\mathrm{Ru}(2)-\mathrm{Ru}(3)$ & $88.1(8)$ \\
\hline $\mathrm{C}(4)-\mathrm{Ru}(2)-\mathrm{Ru}(3)$ & $87.15(10)$ & $C(5)-R u(2)-R u(3)$ & $175.92(9)$ \\
\hline $\mathrm{C}(3)-\mathrm{Ru}(2)-\mathrm{Ru}(3)$ & $89.45(9)$ & $\mathrm{C}(11)-\mathrm{Ru}(2)-\mathrm{Ru}(3)$ & $88.75(7)$ \\
\hline $\mathrm{H}(1)-\mathrm{Ru}(2)-\mathrm{Ru}(1)$ & $35.2(7)$ & $\mathrm{C}(4)-\mathrm{Ru}(2)-\mathrm{Ru}(1)$ & $137.98(9)$ \\
\hline $\mathrm{C}(5)-\mathrm{Ru}(2)-\mathrm{Ru}(1)$ & $117.16(9)$ & $\mathrm{C}(3)-\mathrm{Ru}(2)-\mathrm{Ru}(1)$ & $107.40(9)$ \\
\hline $\mathrm{C}(11)-\mathrm{Ru}(2)-\mathrm{Ru}(1)$ & $67.99(7)$ & $\mathrm{Ru}(3)-\mathrm{Ru}(2)-\mathrm{Ru}(1)$ & $58.950(8)$ \\
\hline $\mathrm{C}(7)-\mathrm{Ru}(3)-\mathrm{C}(9)$ & $102.34(14)$ & $\mathrm{C}(7)-\mathrm{Ru}(3)-\mathrm{C}(8)$ & $93.75(13)$ \\
\hline $\mathrm{C}(9)-\mathrm{Ru}(3)-\mathrm{C}(8)$ & $91.08(13)$ & $\mathrm{C}(7)-\mathrm{Ru}(3)-\mathrm{C}(6)$ & $91.08(12)$ \\
\hline $\mathrm{C}(9)-\mathrm{Ru}(3)-\mathrm{C}(6)$ & $92.92(12)$ & $\mathrm{C}(8)-\mathrm{Ru}(3)-\mathrm{C}(6)$ & $172.93(12)$ \\
\hline $\mathrm{C}(7)-\mathrm{Ru}(3)-\mathrm{Ru}(1)$ & $158.85(11)$ & $\mathrm{C}(9)-\mathrm{Ru}(3)-\mathrm{Ru}(1)$ & $98.73(10)$ \\
\hline $\mathrm{C}(8)-\mathrm{Ru}(3)-\mathrm{Ru}(1)$ & $87.72(9)$ & $\mathrm{C}(6)-\mathrm{Ru}(3)-\mathrm{Ru}(1)$ & $85.92(8)$ \\
\hline $\mathrm{C}(7)-\mathrm{Ru}(3)-\mathrm{Ru}(2)$ & $97.54(11)$ & $C(9)-R u(3)-R u(2)$ & $160.11(10)$ \\
\hline $\mathrm{C}(8)-\mathrm{Ru}(3)-\mathrm{Ru}(2)$ & $86.95(10)$ & $\mathrm{C}(6)-\mathrm{Ru}(3)-\mathrm{Ru}(2)$ & $87.31(8)$ \\
\hline $\mathrm{Ru}(1)-\mathrm{Ru}(3)-\mathrm{Ru}(2)$ & $61.438(8)$ & $\mathrm{C}(41)-\mathrm{P}(1)-\mathrm{C}(51)$ & $102.62(12)$ \\
\hline $\mathrm{C}(41)-\mathrm{P}(1)-\mathrm{C}(21)$ & $105.47(12)$ & $\mathrm{C}(51)-\mathrm{P}(1)-\mathrm{C}(21)$ & $101.15(11)$ \\
\hline $\mathrm{C}(41)-\mathrm{P}(1)-\mathrm{Ru}(1)$ & $108.27(9)$ & $\mathrm{C}(51)-\mathrm{P}(1)-\mathrm{Ru}(1)$ & $117.51(8)$ \\
\hline $\mathrm{C}(21)-\mathrm{P}(1)-\mathrm{Ru}(1)$ & $119.95(9)$ & $\mathrm{C}(15)-\mathrm{N}-\mathrm{C}(11)$ & $121.2(2)$ \\
\hline $\mathrm{C}(15)-\mathrm{N}-\mathrm{Ru}(1)$ & $127.92(18)$ & $\mathrm{C}(11)-\mathrm{N}-\mathrm{Ru}(1)$ & $110.83(15)$ \\
\hline $\mathrm{O}(1)-\mathrm{C}(1)-\mathrm{Ru}(1)$ & $179.8(3)$ & $\mathrm{O}(2)-\mathrm{C}(2)-\mathrm{Ru}(1)$ & $177.4(3)$ \\
\hline $\mathrm{O}(3)-\mathrm{C}(3)-\mathrm{Ru}(2)$ & $176.2(3)$ & $\mathrm{O}(4)-\mathrm{C}(4)-\mathrm{Ru}(2)$ & $177.5(3)$ \\
\hline $\mathrm{O}(5)-\mathrm{C}(5)-\mathrm{Ru}(2)$ & $177.5(3)$ & $\mathrm{O}(6)-\mathrm{C}(6)-\mathrm{Ru}(3)$ & $174.4(3)$ \\
\hline $\mathrm{O}(7)-\mathrm{C}(7)-\mathrm{Ru}(3)$ & $175.6(3)$ & $\mathrm{O}(8)-\mathrm{C}(8)-\mathrm{Ru}(3)$ & $174.8(3)$ \\
\hline $\mathrm{O}(9)-\mathrm{C}(9)-\mathrm{Ru}(3)$ & 179.2(3) & $\mathrm{N}-\mathrm{C}(11)-\mathrm{C}(12)$ & $117.3(2)$ \\
\hline $\mathrm{N}-\mathrm{C}(11)-\mathrm{Ru}(2)$ & $112.84(17)$ & $C(12)-C(11)-R u(2)$ & $129.8(2)$ \\
\hline $\mathrm{C}(13)-\mathrm{C}(12)-\mathrm{C}(11)$ & $121.4(3)$ & $\mathrm{C}(14)-\mathrm{C}(13)-\mathrm{C}(12)$ & $118.9(3)$ \\
\hline $\mathrm{C}(15)-\mathrm{C}(14)-\mathrm{C}(13)$ & 119.1(3) & $\mathrm{N}-\mathrm{C}(15)-\mathrm{C}(14)$ & $122.0(3)$ \\
\hline $\mathrm{C}(26)-\mathrm{C}(21)-\mathrm{C}(22)$ & $118.7(2)$ & $\mathrm{C}(26)-\mathrm{C}(21)-\mathrm{P}(1)$ & $118.5(2)$ \\
\hline $\mathrm{C}(22)-\mathrm{C}(21)-\mathrm{P}(1)$ & $122.7(2)$ & $C(23)-C(22)-C(21)$ & $120.3(3)$ \\
\hline $\mathrm{C}(24)-\mathrm{C}(23)-\mathrm{C}(22)$ & $120.4(3)$ & $C(25)-C(24)-C(23)$ & $120.0(3)$ \\
\hline $\mathrm{C}(24)-\mathrm{C}(25)-\mathrm{C}(26)$ & $120.4(3)$ & $C(25)-C(26)-C(21)$ & $120.2(3)$ \\
\hline $\mathrm{C}(42)-\mathrm{C}(41)-\mathrm{C}(46)$ & $117.9(2)$ & $\mathrm{C}(42)-\mathrm{C}(41)-\mathrm{P}(1)$ & $117.97(19)$ \\
\hline $\mathrm{C}(46)-\mathrm{C}(41)-\mathrm{P}(1)$ & $123.4(2)$ & $C(43)-C(42)-C(41)$ & 121.1(3) \\
\hline $\mathrm{C}(42)-\mathrm{C}(43)-\mathrm{C}(44)$ & $120.2(3)$ & $C(45)-C(44)-C(43)$ & 119.6(3) \\
\hline $\mathrm{C}(44)-\mathrm{C}(45)-\mathrm{C}(46)$ & $120.8(3)$ & $C(45)-C(46)-C(41)$ & $120.3(3)$ \\
\hline $\mathrm{C}(52)-\mathrm{C}(51)-\mathrm{C}(56)$ & $118.0(2)$ & $\mathrm{C}(52)-\mathrm{C}(51)-\mathrm{P}(1)$ & $120.9(2)$ \\
\hline $\mathrm{C}(56)-\mathrm{C}(51)-\mathrm{P}(1)$ & $121.03(19)$ & $C(51)-C(52)-C(53)$ & $120.7(3)$ \\
\hline $\mathrm{C}(54)-\mathrm{C}(53)-\mathrm{C}(52)$ & $120.2(3)$ & $C(53)-C(54)-C(55)$ & $119.4(3)$ \\
\hline $\mathrm{C}(56)-\mathrm{C}(55)-\mathrm{C}(54)$ & $120.7(3)$ & $\mathrm{C}(55)-\mathrm{C}(56)-\mathrm{C}(51)$ & $120.9(3)$ \\
\hline
\end{tabular}

Symmetry transformations used to generate equivalent atoms: 
Ortep diagram for $\mathbf{R u}_{2}\left(\mu-\mathbf{P P h}_{2}\right)\left(\mu-\mathrm{NC}_{5} \mathbf{H}_{4}\right)\left(\mathbf{P P h}_{3}\right)(\mathbf{C O})_{5}(4)$.

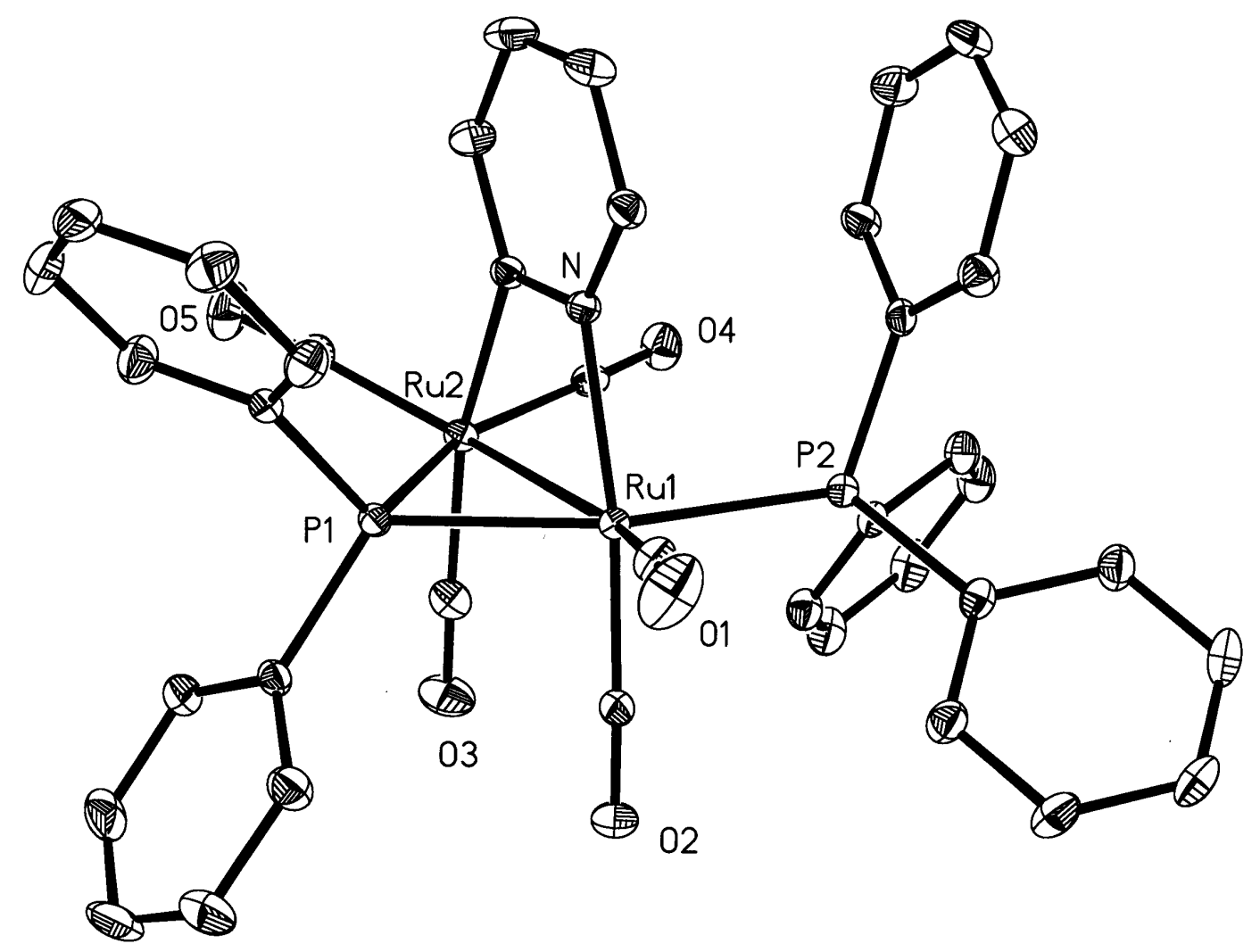


Table 3. Crystal data and structure refinement for $\mathbf{R u}_{2}\left(\mu-\mathbf{P P h}_{2}\right)\left(\mu-\mathbf{N C}_{5} \mathbf{H}_{4}\right)\left(\mathbf{P P h}_{3}\right)(\mathbf{C O})_{5}$ (4).

Identification code

Empirical formula

Formula weight

Temperature

Wavelength

Crystal system

Space group

Unit cell dimensions

Volume, Z

Density (calculated)

Absorption coefficient

F (000)

Crystal size

$\theta$ range for data collection

Limiting indices

Reflections collected

Independent reflections

Completeness to $\theta=28.28^{\circ}$

Absorption correction

Max. and min. transmission

Refinement method

Data / restraints / parameters

Goodness-of-fit on $\mathrm{F}^{2}$

Final $R$ indices $[\mathrm{I}>2 \sigma(\mathrm{I})]$

$\mathrm{R}$ indices (all data)

Extinction coefficient

Largest diff. peak and hole ru3ps 10

$\mathrm{C}_{40} \mathrm{H}_{29} \mathrm{NO}_{5} \mathrm{P}_{2} \mathrm{Ru}_{2}$

867.72

243 (2) K

$0.71073 \AA$

Orthorhombic

Pbca

$a=10.4744$ (6) $\AA$ alpha $=90^{\circ}$

$b=23.1133$ (11) $\AA$ beta $=90^{\circ}$

$c=30.5198$ (17) $\AA$ gamma $=90^{\circ}$

$7388.8(7) \AA^{3}, 8$

$1.560 \mathrm{Mg} / \mathrm{m}^{3}$

$0.948 \mathrm{~mm}^{-1}$

3472

$0.18 \times 0.10 \times 0.10 \mathrm{~mm}$

1.33 to $28.29^{\circ}$

$-13 \leq \mathrm{h} \leq 13,-12 \leq \mathrm{k} \leq 30,-37 \leq 1 \leq 40$

48033

$8725\left(\mathrm{R}_{\mathrm{int}}=0.0670\right)$

$95.2 \%$

SADABS

0.9111 and 0.8478

Full-matrix least-squares on $\mathrm{F}^{2}$

8725 / 0 / 452

1.070

$\mathrm{R} 1=0.0372, \mathrm{wR} 2=0.0792$

$\mathrm{R} 1=0.0804, \mathrm{wR} 2=0.0869$

$0.00023(2)$

0.462 and $-0.479 \mathrm{e}^{-3}$ 
Table 4. Bond lengths $[\AA]$ and angles $\left[^{\circ}\right]$ for $\mathbf{R u}_{2}\left(\mu-\mathbf{P P h}_{2}\right)\left(\mu-\mathbf{N C}_{5} \mathbf{H}_{4}\right)\left(\mathbf{P P h}_{3}\right)(\mathbf{C O})_{5}(\mathbf{4})$.

\begin{tabular}{|c|c|c|c|}
\hline $\mathrm{Ru}(1)-\mathrm{C}(2)$ & $1.868(4)$ & $\mathrm{Ru}(1)-\mathrm{C}(1)$ & $1.903(4)$ \\
\hline $\mathrm{Ru}(1)-\mathrm{N}$ & $2.121(3)$ & $\mathrm{Ru}(1)-\mathrm{P}(1)$ & $2.3207(9)$ \\
\hline $\mathrm{Ru}(1)-\mathrm{P}(2)$ & $2.4023(9)$ & $\mathrm{Ru}(1)-\mathrm{Ru}(2)$ & $2.8165(4)$ \\
\hline $\mathrm{Ru}(2)-\mathrm{C}(5)$ & $1.915(4)$ & $\mathrm{Ru}(2)-\mathrm{C}(4)$ & $1.925(4)$ \\
\hline $\mathrm{Ru}(2)-\mathrm{C}(3)$ & $1.929(5)$ & $\mathrm{Ru}(2)-\mathrm{C}(11)$ & $2.105(4)$ \\
\hline $\mathrm{Ru}(2)-\mathrm{P}(1)$ & $2.3204(10)$ & $P(1)-C(31)$ & $1.815(4)$ \\
\hline$P(1)-C(21)$ & $1.843(4)$ & $P(2)-C(61)$ & $1.823(4)$ \\
\hline$P(2)-C(41)$ & $1.840(4)$ & $\mathrm{P}(2)-\mathrm{C}(51)$ & $1.845(4)$ \\
\hline $\mathrm{O}(1)-\mathrm{C}(1)$ & $1.134(5)$ & $\mathrm{O}(2)-\mathrm{C}(2)$ & $1.152(4)$ \\
\hline $\mathrm{O}(3)-\mathrm{C}(3)$ & $1.139(5)$ & $\mathrm{O}(4)-\mathrm{C}(4)$ & $1.145(4)$ \\
\hline $\mathrm{O}(5)-\mathrm{C}(5)$ & $1.132(4)$ & $\mathrm{N}-\mathrm{C}(15)$ & $1.349(4)$ \\
\hline N-C(11) & $1.364(4)$ & $\mathrm{C}(11)-\mathrm{C}(12)$ & $1.392(5)$ \\
\hline$C(12)-C(13)$ & $1.380(6)$ & $\mathrm{C}(13)-\mathrm{C}(14)$ & $1.372(6)$ \\
\hline$C(14)-C(15)$ & $1.365(5)$ & $\mathrm{C}(21)-\mathrm{C}(22)$ & $1.371(5)$ \\
\hline $\mathrm{C}(21)-\mathrm{C}(26)$ & $1.383(5)$ & $\mathrm{C}(22)-\mathrm{C}(23)$ & $1.387(5)$ \\
\hline$C(23)-C(24)$ & $1.356(6)$ & $\mathrm{C}(24)-\mathrm{C}(25)$ & $1.368(6)$ \\
\hline$C(25)-C(26)$ & $1.396(6)$ & $\mathrm{C}(31)-\mathrm{C}(32)$ & $1.376(5)$ \\
\hline $\mathrm{C}(31)-\mathrm{C}(36)$ & $1.395(5)$ & $\mathrm{C}(32)-\mathrm{C}(33)$ & $1.409(6)$ \\
\hline $\mathrm{C}(33)-\mathrm{C}(34)$ & $1.359(7)$ & $\mathrm{C}(34)-\mathrm{C}(35)$ & $1.360(7)$ \\
\hline$C(35)-C(36)$ & $1.380(6)$ & $\mathrm{C}(41)-\mathrm{C}(42)$ & $1.376(5)$ \\
\hline$C(41)-C(46)$ & $1.404(5)$ & $C(42)-C(43)$ & $1.384(6)$ \\
\hline$C(43)-C(44)$ & $1.383(6)$ & $C(44)-C(45)$ & $1.372(6)$ \\
\hline$C(45)-C(46)$ & $1.391(6)$ & $\mathrm{C}(51)-\mathrm{C}(52)$ & $1.377(5)$ \\
\hline $\mathrm{C}(51)-\mathrm{C}(56)$ & $1.400(5)$ & $\mathrm{C}(52)-\mathrm{C}(53)$ & $1.389(5)$ \\
\hline$C(53)-C(54)$ & $1.364(5)$ & $\mathrm{C}(54)-\mathrm{C}(55)$ & $1.354(6)$ \\
\hline$C(55)-C(56)$ & $1.396(6)$ & $\mathrm{C}(61)-\mathrm{C}(66)$ & $1.387(5)$ \\
\hline $\mathrm{C}(61)-\mathrm{C}(62)$ & $1.394(5)$ & $C(62)-C(63)$ & $1.385(6)$ \\
\hline$C(63)-C(64)$ & $1.351(6)$ & $C(64)-C(65)$ & $1.382(6)$ \\
\hline$C(65)-C(66)$ & $1.391(6)$ & & \\
\hline $\mathrm{C}(2)-\mathrm{Ru}(1)-\mathrm{C}(1)$ & $94.18(17)$ & $\mathrm{C}(2)-\mathrm{Ru}(1)-\mathrm{N}$ & $167.80(14)$ \\
\hline$C(1)-R u(1)-N$ & $96.73(14)$ & $\mathrm{C}(2)-\mathrm{Ru}(1)-\mathrm{P}(1)$ & $90.86(11)$ \\
\hline $\mathrm{C}(1)-\mathrm{Ru}(1)-\mathrm{P}(1)$ & $104.14(11)$ & $\mathrm{N}-\mathrm{Ru}(1)-\mathrm{P}(1)$ & $81.21(8)$ \\
\hline $\mathrm{C}(2)-\mathrm{Ru}(1)-\mathrm{P}(2)$ & $92.67(11)$ & $\mathrm{C}(1)-\mathrm{Ru}(1)-\mathrm{P}(2)$ & $98.05(11)$ \\
\hline $\mathrm{N}-\mathrm{Ru}(1)-\mathrm{P}(2)$ & $91.18(8)$ & $\mathrm{P}(1)-\mathrm{Ru}(1)-\mathrm{P}(2)$ & $157.21(4)$ \\
\hline $\mathrm{C}(2)-\mathrm{Ru}(1)-\mathrm{Ru}(2)$ & $97.56(12)$ & $\mathrm{C}(1)-\mathrm{Ru}(1)-\mathrm{Ru}(2)$ & $153.89(11)$ \\
\hline $\mathrm{N}-\mathrm{Ru}(1)-\mathrm{Ru}(2)$ & $70.27(8)$ & $\mathrm{P}(1)-\mathrm{Ru}(1)-\mathrm{Ru}(2)$ & $52.63(2)$ \\
\hline $\mathrm{P}(2)-\mathrm{Ru}(1)-\mathrm{Ru}(2)$ & $104.57(3)$ & $\mathrm{C}(5)-\mathrm{Ru}(2)-\mathrm{C}(4)$ & $100.71(16)$ \\
\hline $\mathrm{C}(5)-\mathrm{Ru}(2)-\mathrm{C}(3)$ & $100.52(18)$ & $\mathrm{C}(4)-\mathrm{Ru}(2)-\mathrm{C}(3)$ & $93.36(16)$ \\
\hline$C(5)-R u(2)-C(11)$ & $93.94(16)$ & $\mathrm{C}(4)-\mathrm{Ru}(2)-\mathrm{C}(11)$ & $88.29(15)$ \\
\hline $\mathrm{C}(3)-\mathrm{Ru}(2)-\mathrm{C}(11)$ & $164.86(16)$ & $\mathrm{C}(5)-\mathrm{Ru}(2)-\mathrm{P}(1)$ & $102.73(12)$ \\
\hline $\mathrm{C}(4)-\mathrm{Ru}(2)-\mathrm{P}(1)$ & $154.72(12)$ & $\mathrm{C}(3)-\mathrm{Ru}(2)-\mathrm{P}(1)$ & $91.56(12)$ \\
\hline $\mathrm{C}(11)-\mathrm{Ru}(2)-\mathrm{P}(1)$ & $80.82(10)$ & $\mathrm{C}(5)-\mathrm{Ru}(2)-\mathrm{Ru}(1)$ & $151.14(12)$ \\
\hline
\end{tabular}




\begin{tabular}{|c|c|c|c|}
\hline$C(4)-R u(2)-R u(1)$ & $102.17(11)$ & $\mathrm{C}(3)-\mathrm{Ru}(2)-\mathrm{Ru}(1)$ & $95.46(12)$ \\
\hline $\mathrm{C}(11)-\mathrm{Ru}(2)-\mathrm{Ru}(1)$ & $69.51(10)$ & $\mathrm{P}(1)-\mathrm{Ru}(2)-\mathrm{Ru}(1)$ & $52.64(2)$ \\
\hline $\mathrm{C}(31)-\mathrm{P}(1)-\mathrm{C}(21)$ & $102.37(16)$ & $\mathrm{C}(31)-\mathrm{P}(1)-\mathrm{Ru}(2)$ & $119.71(12)$ \\
\hline $\mathrm{C}(21)-\mathrm{P}(1)-\mathrm{Ru}(2)$ & 119.69(12) & $\mathrm{C}(31)-\mathrm{P}(1)-\mathrm{Ru}(1)$ & $121.33(12)$ \\
\hline $\mathrm{C}(21)-\mathrm{P}(1)-\mathrm{Ru}(1)$ & $118.79(12)$ & $\mathrm{Ru}(2)-\mathrm{P}(1)-\mathrm{Ru}(1)$ & $74.73(3)$ \\
\hline $\mathrm{C}(61)-\mathrm{P}(2)-\mathrm{C}(41)$ & $104.70(17)$ & $\mathrm{C}(61)-\mathrm{P}(2)-\mathrm{C}(51)$ & $104.02(17)$ \\
\hline $\mathrm{C}(41)-\mathrm{P}(2)-\mathrm{C}(51)$ & $100.30(16)$ & $\mathrm{C}(61)-\mathrm{P}(2)-\mathrm{Ru}(1)$ & $111.14(11)$ \\
\hline $\mathrm{C}(41)-\mathrm{P}(2)-\mathrm{Ru}(1)$ & $119.75(12)$ & $\mathrm{C}(51)-\mathrm{P}(2)-\mathrm{Ru}(1)$ & $115.18(12)$ \\
\hline C(15)-N-C(11) & $121.3(3)$ & $\mathrm{C}(15)-\mathrm{N}-\mathrm{Ru}(1)$ & $130.0(3)$ \\
\hline $\mathrm{C}(11)-\mathrm{N}-\mathrm{Ru}(1)$ & $108.7(2)$ & $\mathrm{O}(1)-\mathrm{C}(1)-\mathrm{Ru}(1)$ & $174.1(4)$ \\
\hline $\mathrm{O}(2)-\mathrm{C}(2)-\mathrm{Ru}(1)$ & $178.1(3)$ & $\mathrm{O}(3)-\mathrm{C}(3)-\mathrm{Ru}(2)$ & $176.7(4)$ \\
\hline $\mathrm{O}(4)-\mathrm{C}(4)-\mathrm{Ru}(2)$ & $178.3(4)$ & $\mathrm{O}(5)-\mathrm{C}(5)-\mathrm{Ru}(2)$ & $178.2(4)$ \\
\hline N-C(11)-C(12) & $117.5(3)$ & N-C(11)-Ru(2) & $111.5(2)$ \\
\hline$C(12)-C(11)-R u(2)$ & $130.9(3)$ & $C(13)-C(12)-C(11)$ & $121.5(4)$ \\
\hline $\mathrm{C}(14)-\mathrm{C}(13)-\mathrm{C}(12)$ & $118.9(4)$ & $\mathrm{C}(15)-\mathrm{C}(14)-\mathrm{C}(13)$ & $119.5(4)$ \\
\hline N-C(15)-C(14) & $121.4(4)$ & $C(22)-C(21)-C(26)$ & $118.9(4)$ \\
\hline $\mathrm{C}(22)-\mathrm{C}(21)-\mathrm{P}(1)$ & $122.4(3)$ & $\mathrm{C}(26)-\mathrm{C}(21)-\mathrm{P}(1)$ & $118.6(3)$ \\
\hline$C(21)-C(22)-C(23)$ & $121.1(4)$ & $\mathrm{C}(24)-\mathrm{C}(23)-\mathrm{C}(22)$ & $119.9(4)$ \\
\hline$C(23)-C(24)-C(25)$ & $120.1(4)$ & $C(24)-C(25)-C(26)$ & $120.5(4)$ \\
\hline$C(21)-C(26)-C(25)$ & $119.5(4)$ & $\mathrm{C}(32)-\mathrm{C}(31)-\mathrm{C}(36)$ & $118.1(4)$ \\
\hline $\mathrm{C}(32)-\mathrm{C}(31)-\mathrm{P}(1)$ & $121.1(3)$ & $\mathrm{C}(36)-\mathrm{C}(31)-\mathrm{P}(1)$ & $120.8(3)$ \\
\hline $\mathrm{C}(31)-\mathrm{C}(32)-\mathrm{C}(33)$ & $120.2(4)$ & $\mathrm{C}(34)-\mathrm{C}(33)-\mathrm{C}(32)$ & $120.0(5)$ \\
\hline$C(33)-C(34)-C(35)$ & $120.3(5)$ & $C(34)-C(35)-C(36)$ & $120.3(5)$ \\
\hline$C(35)-C(36)-C(31)$ & $120.9(4)$ & $C(42)-C(41)-C(46)$ & $118.2(4)$ \\
\hline $\mathrm{C}(42)-\mathrm{C}(41)-\mathrm{P}(2)$ & 119.7(3) & $\mathrm{C}(46)-\mathrm{C}(41)-\mathrm{P}(2)$ & $122.1(3)$ \\
\hline$C(41)-C(42)-C(43)$ & $121.7(4)$ & $C(44)-C(43)-C(42)$ & $119.8(4)$ \\
\hline $\mathrm{C}(45)-\mathrm{C}(44)-\mathrm{C}(43)$ & $119.6(4)$ & $C(44)-C(45)-C(46)$ & $120.8(4)$ \\
\hline$C(45)-C(46)-C(41)$ & $119.9(4)$ & $C(52)-C(51)-C(56)$ & $118.0(4)$ \\
\hline $\mathrm{C}(52)-\mathrm{C}(51)-\mathrm{P}(2)$ & $121.0(3)$ & $\mathrm{C}(56)-\mathrm{C}(51)-\mathrm{P}(2)$ & $121.0(3)$ \\
\hline$C(51)-C(52)-C(53)$ & $121.2(4)$ & $\mathrm{C}(54)-\mathrm{C}(53)-\mathrm{C}(52)$ & $120.5(4)$ \\
\hline$C(55)-C(54)-C(53)$ & $119.4(4)$ & $C(54)-C(55)-C(56)$ & $121.5(4)$ \\
\hline$C(55)-C(56)-C(51)$ & $119.5(4)$ & $C(66)-C(61)-C(62)$ & $118.4(4)$ \\
\hline $\mathrm{C}(66)-\mathrm{C}(61)-\mathrm{P}(2)$ & $120.1(3)$ & $\mathrm{C}(62)-\mathrm{C}(61)-\mathrm{P}(2)$ & $121.2(3)$ \\
\hline$C(63)-C(62)-C(61)$ & $120.5(4)$ & $C(64)-C(63)-C(62)$ & $120.5(4)$ \\
\hline$C(63)-C(64)-C(65)$ & $120.5(4)$ & $C(64)-C(65)-C(66)$ & $119.7(4)$ \\
\hline$C(65)-C(66)-C(61)$ & $120.4(4)$ & & \\
\hline
\end{tabular}

Symmetry transformations used to generate equivalent atoms: 
Ortep diagram for $\mathbf{R u}_{3}(\mu-\mathrm{H})_{2}\left(\mu-\mathrm{NC}_{5} \mathbf{H}_{4}\right)_{2}\left(\mathbf{P P h}_{3}\right)_{2}(\mathbf{C O})_{6}(\mathbf{5 a}, \mathbf{b})$.

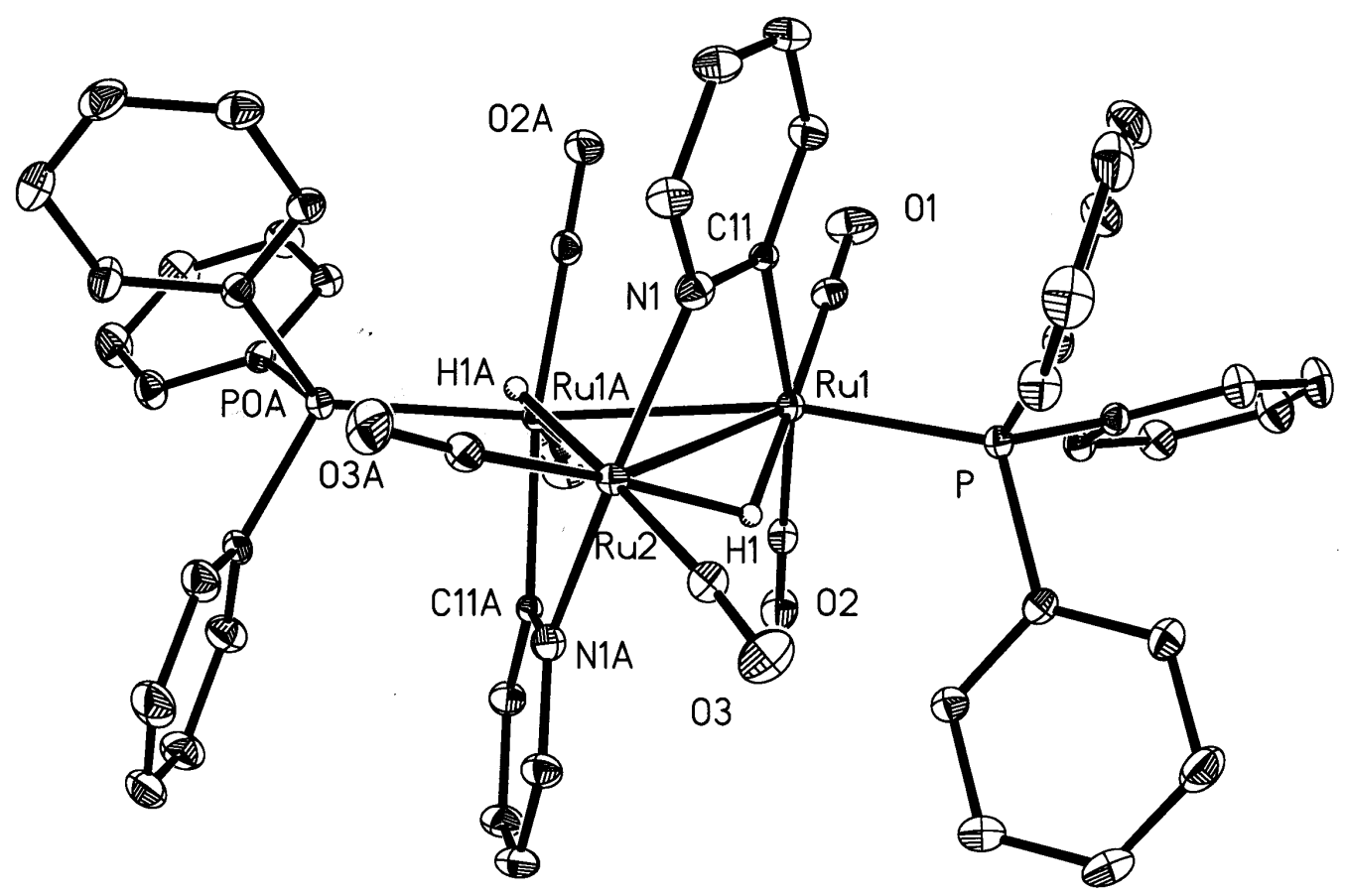


Table 5. Crystal data and structure refinement for $\mathbf{R u}_{3}(\mu-\mathbf{H})_{2}\left(\mu-\mathbf{N C}_{5} \mathbf{H}_{4}\right)_{2}\left(\mathbf{P P h}_{3}\right)_{2}(\mathbf{C O})_{6}$ (5a, b).

Identification code

Empirical formula

Formula weight

Temperature

Wavelength

Crystal system

Space group

Unit cell dimensions

Volume, Z

Density (calculated)

Absorption coefficient

F (000)

Crystal size

$\theta$ range for data collection

Limiting indices

Reflections collected

Independent reflections

Completeness to $\theta=28.28^{\circ}$

Absorption correction

Max. and min. transmission

Refinement method

Data / restraints / parameters

Goodness-of-fit on $\mathrm{F}^{2}$

Final $R$ indices $[\mathrm{I}>2 \sigma(\mathrm{I})]$

$\mathrm{R}$ indices (all data)

Extinction coefficient

Largest diff. peak and hole rupys 10

$\mathrm{C}_{52} \mathrm{H}_{40} \mathrm{~N}_{2} \mathrm{O}_{6} \mathrm{P}_{2} \mathrm{Ru}_{3}$

1154.01

243(2) K

$0.71073 \AA$

Monoclinic

$\mathrm{C} 2 / \mathrm{c}$

$a=34.013$ (2) $\AA$ alpha $=90^{\circ}$

$b=8.9515(5) \AA$ beta $=121.2210(10)^{\circ}$

$c=18.0183$ (11) $\AA$ gamma $=90^{\circ}$

$4691.4(5) \AA^{3}, 4$

$1.634 \mathrm{Mg} / \mathrm{m}^{3}$

$1.074 \mathrm{~mm}^{-1}$

2304

$0.40 \times 0.36 \times 0.22 \mathrm{~mm}$

1.40 to $28.21^{\circ}$

$-44 \leq \mathrm{h} \leq 31,-11 \leq \mathrm{k} \leq 9,-23 \leq 1 \leq 23$

15407

$5321\left(\mathrm{R}_{\mathrm{int}}=0.0185\right)$

$92.0 \%$

SADABS

0.7980 and 0.6733

Full-matrix least-squares on $\mathrm{F}^{2}$

$5321 / 0 / 299$

1.188

$\mathrm{R} 1=0.0216, \mathrm{wR} 2=0.0652$

$\mathrm{R} 1=0.0254, \mathrm{wR} 2=0.0666$

$0.00016(4)$

0.484 and $-0.537 \mathrm{e}^{-3}$ 
Table 6. Bond lengths $[\AA]$ and angles $\left[^{\circ}\right]$ for $\mathbf{R u}_{3}(\mu-\mathbf{H})_{2}\left(\mu-\mathrm{NC}_{5} \mathbf{H}_{4}\right)_{2}\left(\mathbf{P P h}_{3}\right)_{2}(\mathbf{C O})_{6}(\mathbf{5 a}, \mathbf{b})$.

\begin{tabular}{|c|c|c|c|}
\hline $\mathrm{Ru}(1)-\mathrm{H}(1)$ & $1.76(2)$ & $\mathrm{Ru}(1)-\mathrm{C}(1)$ & $1.888(2)$ \\
\hline $\mathrm{Ru}(1)-\mathrm{C}(2)$ & $1.906(2)$ & $\mathrm{Ru}(1)-\mathrm{C}(11)$ & $2.1377(17)$ \\
\hline $\mathrm{Ru}(1)-\mathrm{P}$ & $2.3495(5)$ & $\mathrm{Ru}(1)-\mathrm{Ru}(1) \# 1$ & $2.8429(3)$ \\
\hline $\mathrm{Ru}(1)-\mathrm{Ru}(2)$ & $2.9546(3)$ & $\mathrm{Ru}(2)-\mathrm{H}(1)$ & $1.72(2)$ \\
\hline $\mathrm{Ru}(2)-\mathrm{C}(3)$ & $1.866(2)$ & $\mathrm{Ru}(2)-\mathrm{C}(3) \# 1$ & $1.866(2)$ \\
\hline $\mathrm{Ru}(2)-\mathrm{N}(1)$ & $2.1078(17)$ & $\mathrm{Ru}(2)-\mathrm{N}(1) \# 1$ & $2.1078(17)$ \\
\hline $\mathrm{Ru}(2)-\mathrm{Ru}(1) \# 1$ & $2.9546(3)$ & $\mathrm{P}-\mathrm{C}(41)$ & $1.827(2)$ \\
\hline $\mathrm{P}-\mathrm{C}(31)$ & $1.8421(19)$ & $\mathrm{P}-\mathrm{C}(21)$ & $1.844(2)$ \\
\hline $\mathrm{O}(1)-\mathrm{C}(1)$ & $1.145(2)$ & $\mathrm{O}(2)-\mathrm{C}(2)$ & $1.146(2)$ \\
\hline $\mathrm{O}(3)-\mathrm{C}(3)$ & $1.152(3)$ & $\mathrm{N}(1)-\mathrm{C}(11)$ & $1.351(2)$ \\
\hline $\mathrm{N}(1)-\mathrm{C}(15)$ & $1.370(3)$ & $\mathrm{C}(11)-\mathrm{C}(12)$ & $1.372(3)$ \\
\hline $\mathrm{C}(12)-\mathrm{C}(13)$ & $1.371(3)$ & $\mathrm{C}(13)-\mathrm{C}(14)$ & $1.375(3)$ \\
\hline $\mathrm{C}(14)-\mathrm{C}(15)$ & $1.381(3)$ & $C(21)-C(26)$ & $1.393(3)$ \\
\hline $\mathrm{C}(21)-\mathrm{C}(22)$ & $1.400(3)$ & $\mathrm{C}(22)-\mathrm{C}(23)$ & $1.383(3)$ \\
\hline $\mathrm{C}(23)-\mathrm{C}(24)$ & $1.382(4)$ & $C(24)-C(25)$ & $1.378(3)$ \\
\hline$C(25)-C(26)$ & $1.391(3)$ & $\mathrm{C}(31)-\mathrm{C}(36)$ & $1.394(3)$ \\
\hline $\mathrm{C}(31)-\mathrm{C}(32)$ & $1.397(3)$ & $\mathrm{C}(32)-\mathrm{C}(33)$ & $1.388(3)$ \\
\hline $\mathrm{C}(33)-\mathrm{C}(34)$ & $1.372(4)$ & $C(34)-C(35)$ & $1.390(3)$ \\
\hline$C(35)-C(36)$ & $1.386(3)$ & $\mathrm{C}(41)-\mathrm{C}(42)$ & $1.388(3)$ \\
\hline $\mathrm{C}(41)-\mathrm{C}(46)$ & $1.398(3)$ & $C(42)-C(43)$ & $1.387(3)$ \\
\hline $\mathrm{C}(43)-\mathrm{C}(44)$ & $1.375(4)$ & $C(44)-C(45)$ & $1.377(4)$ \\
\hline$C(45)-C(46)$ & $1.384(3)$ & & \\
\hline $\mathrm{H}(1)-\mathrm{Ru}(1)-\mathrm{C}(1)$ & $178.5(8)$ & $\mathrm{H}(1)-\mathrm{Ru}(1)-\mathrm{C}(2)$ & $87.8(8)$ \\
\hline $\mathrm{C}(1)-\mathrm{Ru}(1)-\mathrm{C}(2)$ & $93.42(9)$ & $\mathrm{H}(1)-\mathrm{Ru}(1)-\mathrm{C}(11)$ & $87.2(8)$ \\
\hline $\mathrm{C}(1)-\mathrm{Ru}(1)-\mathrm{C}(11)$ & $91.41(8)$ & $\mathrm{C}(2)-\mathrm{Ru}(1)-\mathrm{C}(11)$ & $169.53(7)$ \\
\hline $\mathrm{H}(1)-\mathrm{Ru}(1)-\mathrm{P}$ & $84.0(7)$ & $\mathrm{C}(1)-\mathrm{Ru}(1)-\mathrm{P}$ & $96.63(6)$ \\
\hline $\mathrm{C}(2)-\mathrm{Ru}(1)-\mathrm{P}$ & $96.84(6)$ & $\mathrm{C}(11)-\mathrm{Ru}(1)-\mathrm{P}$ & $91.82(4)$ \\
\hline $\mathrm{H}(1)-\mathrm{Ru}(1)-\mathrm{Ru}(1) \# 1$ & $82.3(7)$ & $\mathrm{C}(1)-\mathrm{Ru}(1)-\mathrm{Ru}(1) \# 1$ & $97.12(6)$ \\
\hline $\mathrm{C}(2)-\mathrm{Ru}(1)-\mathrm{Ru}(1) \# 1$ & $79.14(6)$ & $\mathrm{C}(11)-\mathrm{Ru}(1)-\mathrm{Ru}(1) \# 1$ & $91.05(4)$ \\
\hline $\mathrm{P}-\mathrm{Ru}(1)-\mathrm{Ru}(1) \# 1$ & $165.874(14)$ & $\mathrm{H}(1)-\mathrm{Ru}(1)-\mathrm{Ru}(2)$ & $31.6(8)$ \\
\hline $\mathrm{C}(1)-\mathrm{Ru}(1)-\mathrm{Ru}(2)$ & $147.02(6)$ & $\mathrm{C}(2)-\mathrm{Ru}(1)-\mathrm{Ru}(2)$ & $105.25(6)$ \\
\hline $\mathrm{C}(11)-\mathrm{Ru}(1)-\mathrm{Ru}(2)$ & $66.30(5)$ & $\mathrm{P}-\mathrm{Ru}(1)-\mathrm{Ru}(2)$ & $107.565(13)$ \\
\hline $\mathrm{Ru}(1) \# 1-\mathrm{Ru}(1)-\mathrm{Ru}(2)$ & $61.243(4)$ & $\mathrm{H}(1)-\mathrm{Ru}(2)-\mathrm{C}(3)$ & $79.5(8)$ \\
\hline $\mathrm{H}(1)-\mathrm{Ru}(2)-\mathrm{C}(3) \# 1$ & $172.3(8)$ & $\mathrm{C}(3)-\mathrm{Ru}(2)-\mathrm{C}(3) \# 1$ & $92.77(13)$ \\
\hline $\mathrm{H}(1)-\mathrm{Ru}(2)-\mathrm{N}(1)$ & $88.3(8)$ & $\mathrm{C}(3)-\mathrm{Ru}(2)-\mathrm{N}(1)$ & $99.47(8)$ \\
\hline $\mathrm{C}(3) \# 1-\mathrm{Ru}(2)-\mathrm{N}(1)$ & $93.22(8)$ & $\mathrm{H}(1)-\mathrm{Ru}(2)-\mathrm{N}(1) \# 1$ & $80.9(8)$ \\
\hline $\mathrm{C}(3)-\mathrm{Ru}(2)-\mathrm{N}(1) \# 1$ & $93.22(8)$ & $\mathrm{C}(3) \# 1-\mathrm{Ru}(2)-\mathrm{N}(1) \# 1$ & $99.47(8)$ \\
\hline $\mathrm{N}(1)-\mathrm{Ru}(2)-\mathrm{N}(1) \# 1$ & $161.58(10)$ & $\mathrm{H}(1)-\mathrm{Ru}(2)-\mathrm{Ru}(1) \# 1$ & $79.4(8)$ \\
\hline $\mathrm{C}(3)-\mathrm{Ru}(2)-\mathrm{Ru}(1) \# 1$ & $154.34(7)$ & $\mathrm{C}(3) \# 1-\mathrm{Ru}(2)-\mathrm{Ru}(1) \# 1$ & $107.94(7)$ \\
\hline $\mathrm{N}(1)-\mathrm{Ru}(2)-\mathrm{Ru}(1) \# 1$ & $94.42(5)$ & $\mathrm{N}(1) \# 1-\mathrm{Ru}(2)-\mathrm{Ru}(1) \# 1$ & $69.04(5)$ \\
\hline $\mathrm{H}(1)-\mathrm{Ru}(2)-\mathrm{Ru}(1)$ & $32.3(8)$ & $\mathrm{C}(3)-\mathrm{Ru}(2)-\mathrm{Ru}(1)$ & $107.94(6)$ \\
\hline $\mathrm{C}(3) \# 1-\mathrm{Ru}(2)-\mathrm{Ru}(1)$ & $154.34(7)$ & $\mathrm{N}(1)-\mathrm{Ru}(2)-\mathrm{Ru}(1)$ & $69.04(5)$ \\
\hline
\end{tabular}




$\begin{array}{llll}\mathrm{N}(1) \# 1-\mathrm{Ru}(2)-\mathrm{Ru}(1) & 94.42(5) & \mathrm{Ru}(1) \# 1-\mathrm{Ru}(2)-\mathrm{Ru}(1) & 57.514(7) \\ \mathrm{C}(41)-\mathrm{P}-\mathrm{C}(31) & 104.37(9) & \mathrm{C}(41)-\mathrm{P}-\mathrm{C}(21) & 102.34(9) \\ \mathrm{C}(31)-\mathrm{P}-\mathrm{C}(21) & 100.24(9) & \mathrm{C}(41)-\mathrm{P}-\mathrm{Ru}(1) & 114.13(6) \\ \mathrm{C}(31)-\mathrm{P}-\mathrm{Ru}(1) & 117.17(6) & \mathrm{C}(21)-\mathrm{P}-\mathrm{Ru}(1) & 116.49(6) \\ \mathrm{O}(1)-\mathrm{C}(1)-\mathrm{Ru}(1) & 177.43(19) & \mathrm{O}(2)-\mathrm{C}(2)-\mathrm{Ru}(1) & 179.12(18) \\ \mathrm{O}(3)-\mathrm{C}(3)-\mathrm{Ru}(2) & 175.9(2) & \mathrm{C}(11)-\mathrm{N}(1)-\mathrm{C}(15) & 120.61(18) \\ \mathrm{C}(11)-\mathrm{N}(1)-\mathrm{Ru}(2) & 110.06(12) & \mathrm{C}(15)-\mathrm{N}(1)-\mathrm{Ru}(2) & 128.82(15) \\ \mathrm{N}(1)-\mathrm{C}(11)-\mathrm{C}(12) & 118.24(17) & \mathrm{N}(1)-\mathrm{C}(11)-\mathrm{Ru}(1) & 113.70(12) \\ \mathrm{C}(12)-\mathrm{C}(11)-\mathrm{Ru}(1) & 128.04(14) & \mathrm{C}(13)-\mathrm{C}(12)-\mathrm{C}(11) & 122.3(2) \\ \mathrm{C}(12)-\mathrm{C}(13)-\mathrm{C}(14) & 119.2(2) & \mathrm{C}(13)-\mathrm{C}(14)-\mathrm{C}(15) & 118.3(2) \\ \mathrm{N}(1)-\mathrm{C}(15)-\mathrm{C}(14) & 121.3(2) & \mathrm{C}(26)-\mathrm{C}(21)-\mathrm{C}(22) & 117.80(19) \\ \mathrm{C}(26)-\mathrm{C}(21)-\mathrm{P} & 121.60(15) & \mathrm{C}(22)-\mathrm{C}(21)-\mathrm{P} & 120.58(16) \\ \mathrm{C}(23)-\mathrm{C}(22)-\mathrm{C}(21) & 121.0(2) & \mathrm{C}(24)-\mathrm{C}(23)-\mathrm{C}(22) & 120.2(2) \\ \mathrm{C}(25)-\mathrm{C}(24)-\mathrm{C}(23) & 119.8(2) & \mathrm{C}(24)-\mathrm{C}(25)-\mathrm{C}(26) & 120.1(2) \\ \mathrm{C}(25)-\mathrm{C}(26)-\mathrm{C}(21) & 121.0(2) & \mathrm{C}(36)-\mathrm{C}(31)-\mathrm{C}(32) & 118.37(18) \\ \mathrm{C}(36)-\mathrm{C}(31)-\mathrm{P} & 118.00(14) & \mathrm{C}(32)-\mathrm{C}(31)-\mathrm{P} & 123.45(15) \\ \mathrm{C}(33)-\mathrm{C}(32)-\mathrm{C}(31) & 120.3(2) & \mathrm{C}(34)-\mathrm{C}(33)-\mathrm{C}(32) & 120.8(2) \\ \mathrm{C}(33)-\mathrm{C}(34)-\mathrm{C}(35) & 119.7(2) & \mathrm{C}(36)-\mathrm{C}(35)-\mathrm{C}(34) & 119.9(2) \\ \mathrm{C}(35)-\mathrm{C}(36)-\mathrm{C}(31) & 120.95(19) & \mathrm{C}(42)-\mathrm{C}(41)-\mathrm{C}(46) & 118.2(2) \\ \mathrm{C}(42)-\mathrm{C}(41)-\mathrm{P} & 121.91(17) & \mathrm{C}(46)-\mathrm{C}(41)-\mathrm{P} & 119.09(17) \\ \mathrm{C}(43)-\mathrm{C}(42)-\mathrm{C}(41) & 120.7(2) & \mathrm{C}(44)-\mathrm{C}(43)-\mathrm{C}(42) & 120.3(3) \\ \mathrm{C}(43)-\mathrm{C}(44)-\mathrm{C}(45) & 120.1(2) & \mathrm{C}(44)-\mathrm{C}(45)-\mathrm{C}(46) & 119.9(3) \\ \mathrm{C}(45)-\mathrm{C}(46)-\mathrm{C}(41) & 120.9(2) & & \end{array}$

Symmetry transformations used to generate equivalent atoms:

$\# 1-\mathrm{x}, \mathrm{y},-\mathrm{z}+1 / 2$

\section{References}

1. Bruce, M. I.; Humphrey, M. G.; Snow, M. R.; Tiekink, E. R. T.; Wallis, R. C J. Organomet. Chem. 1986, 314, 311-322.

2. Foulds, G. A.; Johnson, B.F. G.; Lewis, J. J. Organomet. Chem. 1985, 296, 147153. 